Кельчевская Н.Р., Пелымская И.С., Баскакова И.В.

\title{
УПРАВЛЕНИЕ ИНТЕЛЛЕКТУАЛЬНОЙ ДОБАВЛЕННОЙ СТОИМОСТЬЮ НА ПРОМЫШЛЕННОМ ПРЕДПРИЯТИИ
} монография

Natalia R. Kelchevskaya, Irina S. Pelymskaya, Irina V. Baskakova Managing intellectual value added at industrial enterprise (monograph) Moscow, 2019 
УДК 334.02

ББК 65.050

К348

\section{Рецензенты:}

Романова О.А. - доктор экономических наук, главный научный сотрудник отдела региональной промышленной политики и экономической безопасности Института экономики УрО РАН.

Юзвович Л.И. - доктор экономических наук, профессор, зав. кафедрой финансов, денежного обращения и кредита УрГЭУ-СИНХ.

Кельчевская Н.Р.

К348 Управление интеллектуальной добавленной стоимостью на промышленном предприятии: монография / Н.Р. Кельчевская, И.С. Пелымская, И.В. Баскакова. - М.: Креативная экономика, 2019. - 108 с.

ISBN 978-5-91292-280-0

DOI $10.18334 / 9785912922800$

Монография посвящена исследованию концептуальных подходов к управлению интеллектуальной добавленной стоимостью предприятий в современных условиях. В монографии приведены как теоретические, так и методические основы управления интеллектуальной добавленной стоимостью.

В монографии исследуются основные теоретические аспекты концепции интеллектуальной добавленной стоимости в менеджменте, авторами определены и развиты методические основы измерения и проанализированы особенности управления интеллектуальной добавленной стоимостью на промышленном предприятии, разработана модель управления интеллектуальной добавленной стоимостью.

Монография может быть полезна студентам, аспирантам, экономистам, руководителям предприятий и практическим работниками в области управления интеллектуальным капиталом.

Ключевые слова: интеллектуальная добавленная стоимость, промышленное предприятие, модель управления, стратегия, исследование, управление.

ISBN 978-5-91292-280-0

(C) Коллектив авторов, 2019

(C) Оформление, дизайн обложки

ООО Издательство «Креативная экономика», 2019 


\section{СОДЕРЖАНИЕ}

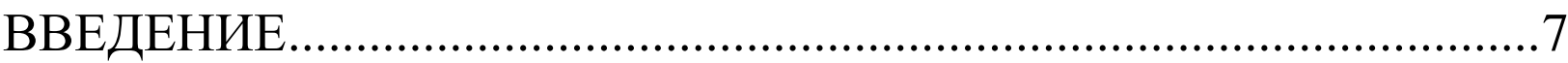

ГЛава 1. КОНЦЕПТУАЛЬНЫЕ ПОДХОДЫ К ИССЛЕДОВАНИЮ ИНТЕЛЛЕКТУАЛЬНОЙ ДОБАВЛЕННОЙ СТОИМОСТИ.............10

1.1. Интеллектуальная добавленная стоимость компании как объект

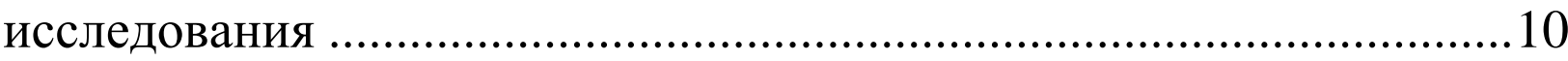

1.2. Методики измерения интеллектуальной добавленной стоимости на предприятии ...............................................................................28

1.3. Стратегические модели управления созданием интеллектуальной добавленной стоимости .40

Глава 2. МОНИТОРИНГ СОЗДАНИЯ И УПРАВЛЕНИЯ ИНТЕЛЛЕКТУАЛЬНОЙ ДОБАВЛЕННОЙ СТОИМОСТЬЮ НА ПРОМЫШЛЕННЫХ ПРЕДПРИЯТИЯХ В РФ.... 46

2.1. Состояние и проблемы создания интеллектуальной добавленной стоимости на промышленных предприятиях .46

2.2. Особенности управления интеллектуальной добавленной стоимостью на промышленных предприятиях.

Глава 3. ЭМПИРИЧЕСКОЕ ИССЛЕДОВАНИЕ ИНТЕЛЛЕКТУАЛЬНОЙ ДОБАВЛЕННОЙ СТОИМОСТИ ПРОМЫШЛЕННОГО ПРЕДПРИЯТИЯ .68

3.1. Разработка модели управления интеллектуальной добавленной стоимостью на промышленном предприятии .68

3.2. Оценка интеллектуальной добавленной стоимости предприятия АО УЭМ .73

3.3. Разработка мероприятий по управлению интеллектуальной добавленной стоимостью на примере АО УЭМ ..............................79

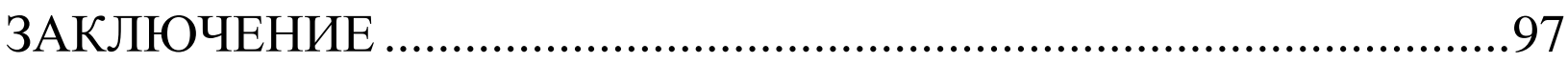

БИБЛИОГРАФИЧЕСКИЙ СПИСОК…………..............................100 


\section{MANAGING INTELLECTUAL VALUE ADDED \\ AT INDUSTRIAL ENTERPRISE}

\section{CONTENTS}

INTRODUCTION

Chapter 1.CONCEPTUAL APPROACHES TO THE STUDY OF INTELLECTUAL VALUE ADDED

1.1. Intellectual value added of the company as an object of research...10

1.2. Methods for measuring intellectual value added at the enterprise ..28

1.3. Strategic models for managing intellectual value added

Chapter 2. MONITORING THE CREATION AND MANAGEMENT OF INTELLECTUAL VALUE ADDED AT INDUSTRIAL ENTERPRISES IN THE RUSSIAN FEDERATION .46

2.1. Condition and problems of creating intellectual value added at industrial enterprises

2.2. Features of managing intellectual value added at industrial enterprises

Chapter 3. EMPIRICAL STUDY OF INTELLECTUAL VALUE ADDED OF INDUSTRIAL ENTERPRISE .68

3.1. Development of a model for managing intellectual value added at

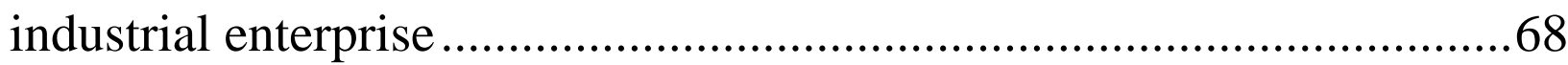

3.2. Assessment of intellectual value added of JSC UEM ......................73

3.3. Development of measures for managing intellectual value added using an example of JSC UEM ........................................................

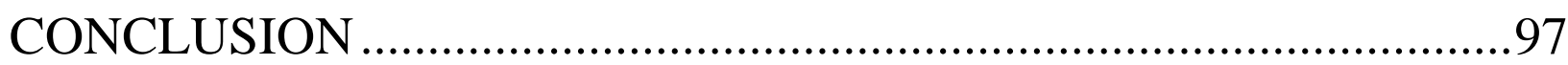

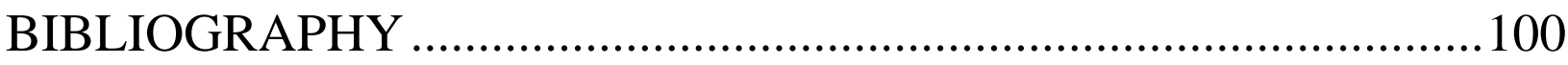


The monograph is devoted to the study of conceptual approaches to the management of intellectual value added of enterprises in modern conditions. The monograph gives theoretical and methodological foundations of managing intellectual value added.

The monograph studies the main theoretical aspects of the concept of intellectual value added in management. The authors have defined and developed methodological foundations of measurement and analyzed the features of managing intellectual value added at an industrial enterprise; the authors have also developed a model for managing intellectual value added.

The monograph may be useful to students, graduate students, economists, business leaders and practitioners in the field of intellectual capital management.

Keywords: intellectual value added, industrial enterprise, management model, strategy, research, management. 



\section{ВВЕДЕНИЕ}

Информация и знания сегодня играют ключевую роль во всех сферах человеческой жизни. Современное развитие мировой экономики предполагает активное использование интеллектуальных и информационных ресурсов в деятельности компании. На данном этапе развития общества все важнее оказывается тот капитал, который воплощается в знаниях, опыте, навыках и умениях. На этом фоне в течение последних нескольких лет значительно возрос интерес к термину «интеллектуальный капитал». Постепенно приходит и осознание его роли в жизни предприятий.

Традиционно в компаниях наиболее важными ресурсами считаются материальные активы, в особенности физические активы и капитал. Действительно, эти ресурсы играют важнейшую роль в создании стоимости компании. Тем не менее высокая конкурентоспособность фирмы невозможна в наше время без интеллектуального капитала, которому принадлежит главная роль в повышении конкурентоспособности и рыночной стоимости той или иной компании.

Современная экономика в основном состоит из компаний, в которых бизнес-модели опираются на ресурсы интеллектуального капитала. Такие фирмы связаны с программным обеспечением, производством средств связи, IT разработками, не обладают большим запасом физического капитала, но опираются на человеческий капитал, иными словами, опыт, знания и навыки работников. Если взглянуть на фирмы с точки зрения финансов, то результаты их деятельности могут быть одинаковыми, но при сравнении ресурсов интеллектуального капитала фирм разница может быть очевидной.

Толчок к развитию теории интеллектуального капитала был сделан зарубежными исследователями: К. Свейби, Э. Брукинг, Т. Стюарт, С. Альберт, К. Бредли, Дж. Даум, именно они в своих работах закладывают основную теорию об интеллектуальном капита- 
ле. В дальнейшем к исследованию проблемы обратились Л. Эдвинсон, Й. Руус, С. Пайк и Л. Фернстрём и другие.

Свой вклад в развитие теории интеллектуального капитала внесли отечественные авторы, такие как Б.Б. Леонтьев, А.И. Колганов и В.Л. Иноземцев, И.В. Ивашковская, Э.Р. Байбурина и другие.

Несмотря на значительное количество работ, посвященных исследованию обозначенной проблемы, вопрос о том, возможно ли оценить такой многогранный актив, как интеллектуальный капитал, до сих пор является дискуссионным. Сложность заключается прежде всего в наличии разнородных данных и специфичности предмета оценки.

В то время как написано большое количество академических статей в попытке определить сущность и дать соответствующее определение интеллектуальному капиталу, практиков волнует вопрос об измерении интеллектуального капитала компании. Данное направление исследования в настоящее время является очень популярным, поскольку для компаний и учёных приоритетным становится вопрос о том, как и в какой степени интеллектуальный капитал влияет на деятельность компании и чего можно добиться, обладая таким знанием, чтобы улучшить ее финансовые показатели.

Стратегическая роль интеллектуальных активов, в том числе и для предприятий, работающих на развивающихся рынках, требует от ученых и экспертов качественных эмпирических исследований, позволяющих проводить сравнительный анализ, выявлять общие закономерности и факторы влияния на эффективность использования нематериальной составляющей ресурсов компании. Для этой цели чаще всего используется интеллектуальный коэффициент добавленной стоимости (VAIC), который был предложен А. Пулик в 2000 году [1]. С его помощью определяется вклад в добавленную стоимость интеллектуального капитала компании. Исследованиями в области интеллектуальной добавленной стоимости занимались также отече- 
ственные авторы: Осколкова М.А, Головко Т.В. и др.

Исследование вклада в добавленную стоимость интеллектуального капитала компании представляет собой новое направление развития экономики фирмы. Следовательно, и управление интеллектуальной добавленной стоимостью на предприятии является актуальной проблемой современного бизнеса. Это связано с тем, что, вопервых, отсутствует единая общепринятая методология оценки и измерения интеллектуальной добавленной стоимости, а во-вторых, современная бухгалтерская отчётность не способна учитывать новые активы.

Целью данной монографии является развитие теоретических и методических положений об интеллектуальном капитале, способах измерения его вклада в результаты деятельности фирмы для разработки модели управления интеллектуальной добавленной стоимостью.

Достижение поставленной цели исследования обусловливает постановку и предполагает решение следующих задач:

1. Изучить совокупность теоретико-методических вопросов, связанных с управлением интеллектуальной добавленной стоимостью на предприятиях.

2. Проанализировать состояние и проблемы в управлении интеллектуальной добавленной стоимостью на предприятиях.

3. Разработать модель для эффективного управления добавленной интеллектуальной стоимостью на предприятиях.

Теоретической и методической основой исследования являются труды отечественных и зарубежных авторов по проблемам инновационного менеджмента, управления интеллектуальным, человеческим, структурным и организационным капиталом.

Поставленные цели и задачи определили структуру монографии, которая состоит из введения, 3 глав, заключения и списка литературы. 


\section{ГЛАВА 1. КОНЦЕПТУАЛЬНЫЕ ПОДХОДЫ К ИССЛЕДОВАНИЮ ИНТЕЛЛЕКТУАЛЬНОЙ ДОБАВЛЕННОЙ СТОИМОСТИ}

\section{1. Интеллектуальная добавленная стоимость компании как объект исследования}

Развитие современного промышленного производства все больше опирается на процессы эффективного использования интеллектуальных ресурсов, которые в ходе совершенствования управленческих и производственных технологий превращаются в интеллектуальный капитал. Известно, что первые попытки определения понятия «интеллектуальный капитал» и выделения его из абстрактного набора интеллектуальных ресурсов были сделаны в 60-е гг. XX столетия в работах П. Друкера, М. П. Фолетт и др., однако полноценное развитие теория получила в первой половине 90-х гг. XX столетия. Термин «интеллектуальный капитал» появился в работах, посвященных исследованиям постиндустриального и информационного общества, обративших особое внимание на этот феномен в 80-90-х гг. XX столетия как результат процессов информатизации и интеллектуализации экономик развитых стран. Тем не менее, очевидно, при достаточно широком использовании понятия интеллектуального капитала до сих пор в научных и практических дискуссиях не существует единой и общепринятой его трактовки. В первую очередь это связано с тем, что создание ценности в организациях привязано, как правило, к различным интеллектуальным активам - от человеческого капитала до готовых интеллектуальных продуктов.

Далее необходимо уяснить суть понятия капитал и определить его значение для целей управления. В литературе большинство авторов не придают большого значения различиям между интеллектуальными ресурсами, активами и капиталом. В общем-то, в практических целях управления данная строгая категоризация не играет су- 
щественной роли. Однако следует понимать, что капитал - это, прежде всего, только тот запас какого-либо ресурса (в том числе и неосязаемого), который способен приносить поток доходов в будущем. При формировании интеллектуального капитала существенная роль отводится человеческим ресурсам и способам управления человеческим капиталом - от приобретения человеческого капитала на рынке труда до сохранения и развития ключевых сотрудников. Под человеческим капиталом понимаются знания, умения и навыки людей, которые могут быть использованы ими на рынке труда для получения дополнительных доходов. Важно отметить, что на уровне организации капитальное значение имеют только те знания и навыки, которые могут быть эффективно применены в конкретных деловых ситуациях.

На рубеже 1980-х и 1990-х годов появляются работы, в которых авторы, осознавая значение и необходимость измерения интеллектуального капитала, пытаются понять его сущность и природу. Например, К. Свейби, Э. Брукинг, Т. Стюарт, С. Альберт, К. Бредли, Дж. Даум закладывают основную теорию об интеллектуальном капитале. Тем не менее до сих пор не существует консенсуса в определении и структурном содержании интеллектуального капитала. Среди прочего, проблема кроется в разных спецификациях отдельных компаний, поэтому содержание понятия «интеллектуальный капитал» будет меняться в зависимости от этого.

Термин «интеллектуальный капитал» впервые был введён Томасом А. Стюартом в 1990-х годах. Он определял интеллектуальный капитал как интеллектуальный материал, включающий в себя знания, опыт, информацию, интеллектуальную собственность и участвующий в создании ценностей [2]. В соответствии с таким пониманием интеллектуальный материал сформирован и используется для производства более ценного имущества.

В работе «Интеллектуальный капитал. Новый источник богат- 
ства компаний» Томас Стюарт ввел трёхкомпонентную структуру интеллектуального капитала (человеческий капитал, структурный и потребительский), которая в настоящее время является наиболее распространённой в исследованиях (рисунок 1).

\section{Человеческий капитал \\ + Структурный капитал \\ + Потребительский капитал}

\section{Интеллектуальный капитал}

Рисунок 1. Трёхкомпонентная структура интеллектуального капитала по T.A. Стюарту [2]

Человеческий капитал заключён в сотрудниках компании. Сюда входят компетенция, практические навыки, отношение к работе, умения и способности, неявные знания, личные связи и т.П. Структурный капитал заключён в знаниях, которые «принадлежат организации»: технология, изобретения, патенты, ноу-хау, процессы, системы, структура и внутренние правила, стратегия и культура компании. Потребительский капитал заключён в отношениях, которые устанавливает организация, т.е. определяется отношениями с клиентами, потребителями, внешними партнёрами организации, индивидуальным подходом, сотрудничеством. Все три компонента взаимодействуют между собой и формируют основу для конкурентного преимущества компании. Лейф Эдвинсон определяет интеллектуальный капитал как «информацию и знания, применяемые для создания ценности» [3]. Предложенная им структура (рисунок 2) много общего имеет со структурой Т. Стюарта, но есть в ней и отличие.

Организационный капитал вместе с клиентским (потребительским) входит в состав структурного. Сам же организационный капитал делится на инновационный капитал (патенты, идеи, торговые 
марки) и процессный капитал (информационные технологии, рабочие процессы).

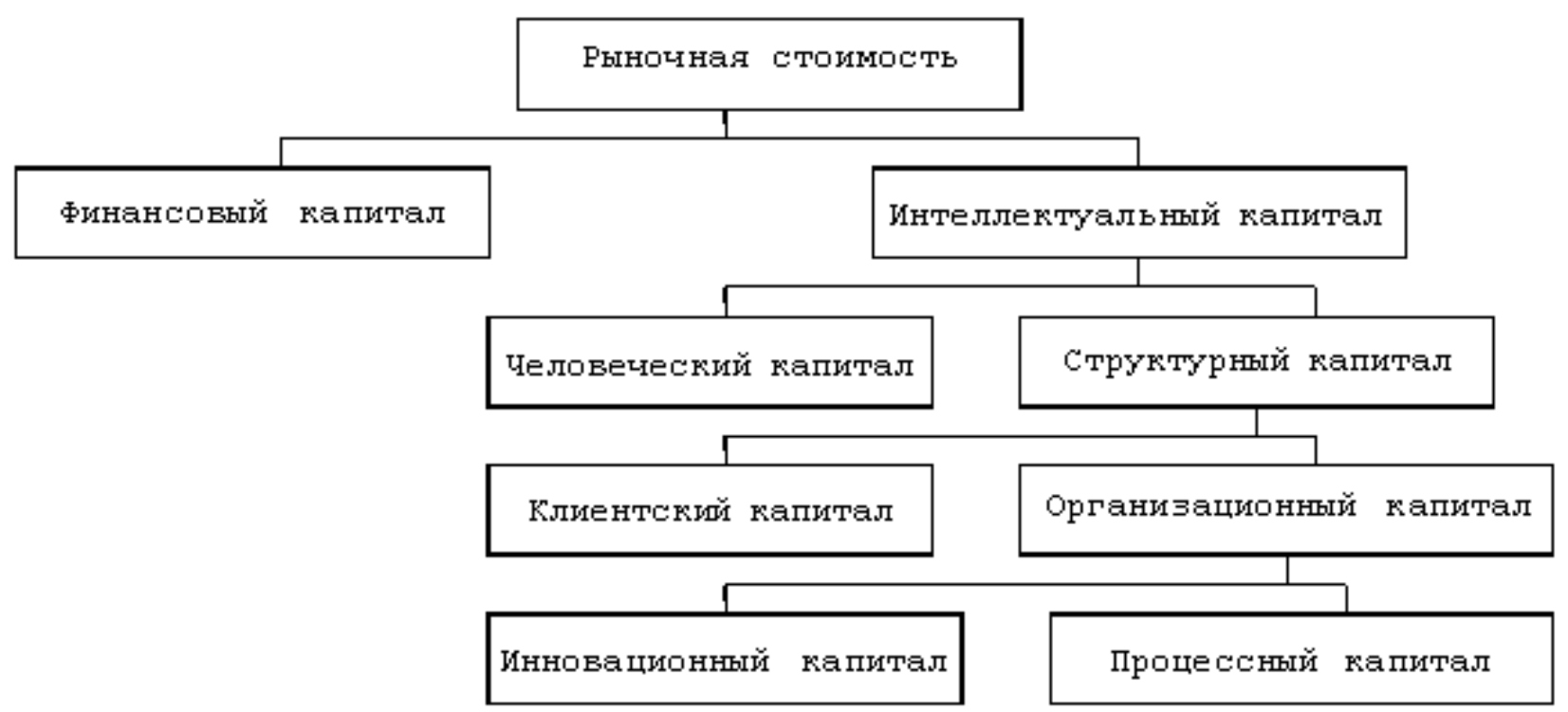

Рисунок 2. Структура интеллектуального капитала по Л. Эдвинссону [3]

Тем не менее при достаточно широком использовании понятия «интеллектуальный капитал» до сих пор в научных дискуссиях не существует единого и общепринятого определения понятия. В трактовке А. Прусака это интеллектуальный материал фирмы, который формализован и собран воедино, чтобы воплотиться в активах фирмы. В. Ефремов определяет интеллектуальный капитал как «знания, которыми располагает компания, выраженные в определенной форме, ясной и доступной профессиональному кругу лиц». В. Иноземцев определяет понятие «интеллектуальный капитал» как «коллективный мозг», вобравший научные и профессиональные знания работников, накопленный опыт и интеллектуальную собственность, коммуникации и информационную структуру, имидж фирмы и информационные сети. Под понятием «интеллектуальный капитал» организации Б. Леонтьев понимает стоимость совокупности имеющихся у компании интеллектуальных активов, в том числе интеллектуальную собственность, интеллектуальные способности и навыки персонала [34]. 
Таким образом, мы видим, что каждая школа экономистов определяет это социально-экономическое явление по-разному. Однако все они сходятся в одном: работник создает с помощью своего интеллекта особые продукты - интеллектуальные. Более того, сотрудник таким образом увеличивает объем собственных знаний и навыков, компетентно управляет новейшими производственными средствами, участвуя в производстве прибавочного продукта. Рассмотрим определение понятия «интеллектуальный капитал» через понятие «нематериальные активы». Одна из распространенных в научных кругах точка зрения на интеллектуальный капитал была сформулирована главой консалтинговой компании Э. Брукинг: «Мы идентифицировали четыре категории неосязаемых активов: человеческие ресурсы, права на интеллектуальную собственность, инфраструктуру и положение на рынке - они обозначаются общим термином “интеллектуальный капитал”» [4]. Интерес к «невидимым» объектам, находящимся до определенного времени вне центра внимания компаний, стал всеобщим. Нематериальные активы имеют определенную стоимость для компании, хотя и обладают иной формой представления по сравнению с физическими предметами. Такие нематериальные активы, как патенты, авторские права и торговые марки, были признаны много лет назад.

Однако лишь немногие компании попытались дать денежную оценку нематериальным активам. На сегодняшний день сущность нематериальных активов в различной литературе и нормативных актах рассматривается с разных сторон, поэтому существует большое количество трактовок сущности и структуры неосязаемых активов. Классификация подходов различных авторов к пониманию интеллектуального капитала через понятие неосязаемые активы представлена в таблице 1. 
Таблийа 1. Содержание понятия «интеллектуальный капитал»

\begin{tabular}{|c|c|}
\hline Автор & Содержание \\
\hline $\begin{array}{l}\text { Т. Стюарт } \\
\text { [2] }\end{array}$ & $\begin{array}{l}\text { Интеллектуальный капитал - это сумма знаний сотрудников } \\
\text { организации и всего того, что предоставляет конкурентное } \\
\text { преимущество организации на рынке: «...патенты, процессы, } \\
\text { управленческие навыки, технологии, опыт и информация о по- } \\
\text { требителях и поставщиках. Объединенные вместе, эти знания } \\
\text { составляют «интеллектуальный капитал». «Интеллектуальный } \\
\text { материал, который сформирован, закреплен за компанией и } \\
\text { используется для производства более ценного имущества. Ра- } \\
\text { зум становится имуществом, когда под влиянием свободно } \\
\text { действующей силы мозга создается нечто полезное, имеющее } \\
\text { определенную форму: перечень сведений, база данных, описа- } \\
\text { ние процесса и.т.д.». «Интеллектуальный капитал - это эконо- } \\
\text { мическая ценность двух категорий неосязаемого имущества } \\
\text { компании: организационный (структурный) капитал и челове- } \\
\text { ческий капитал». }\end{array}$ \\
\hline $\begin{array}{l}\text { Э. Брукинг } \\
\text { [4] }\end{array}$ & $\begin{array}{l}\text { Интеллектуальный капитал - это термин, присваиваемый ком- } \\
\text { бинированным нематериальным активам, которые дают орга- } \\
\text { низации возможность функционировать. }\end{array}$ \\
\hline $\begin{array}{l}\text { Й. Руус, } \\
\text { С. Пайк } \\
{[5]}\end{array}$ & $\begin{array}{l}\text { Интеллектуальный капитал - все неденежные и нематериаль- } \\
\text { ные ресурсы, которые частично или полностью контролируют- } \\
\text { ся организацией и участвуют в создании ценности. }\end{array}$ \\
\hline $\begin{array}{l}\text { В. Макаров, } \\
\text { А. Козырев } \\
{[12]}\end{array}$ & $\begin{array}{l}\text { Понятие «интеллектуальный капитал» применяется в основном } \\
\text { менеджерами в процессе управления персоналом и нематери- } \\
\text { альными активами, при создании положительного образа ком- } \\
\text { пании с целью привлечения дополнительных инвестиций и при } \\
\text { оценке стоимости бизнеса, базирующегося на знаниях. } \\
\text { Понятие «интеллектуальный капитал» шире, чем «нематери- } \\
\text { альные активы» и «интеллектуальная собственность», и не ре- } \\
\text { гламентируется нормативными актами. Содержание нематери- } \\
\text { альных активов жестко регламентируется бухгалтерскими } \\
\text { стандартами и правовыми актами. }\end{array}$ \\
\hline
\end{tabular}


Продолжение Таблицы 1

\begin{tabular}{|c|c|}
\hline $\begin{array}{l}\text { А. Уайлмен, } \\
\text { И. Кадди } \\
\text { [14] }\end{array}$ & $\begin{array}{l}\text { Интеллектуальный капитал интегрирует в ту часть неосязаемо- } \\
\text { го, которая не может иметь денежной оценки и которая неот- } \\
\text { делима от организации, создавшей её, в отличие от неосязае- } \\
\text { мых активов, которые можно измерить в денежном эквивален- } \\
\text { те и которые могут существовать за пределами организации. } \\
\text { Интеллектуальный капитал относится к «мягким» активам, не- } \\
\text { осязаемые активы - кжестким». }\end{array}$ \\
\hline $\begin{array}{l}\text { К.Э. Свейби } \\
{[23]}\end{array}$ & $\begin{array}{l}\text { Рассматривает нематериальные активы и интеллектуальный } \\
\text { капитал как тождественные понятия. Индивидуальная компе- } \\
\text { тентность - это способность людей действовать в различных } \\
\text { ситуациях. Включает образование, умения, социальные навы- } \\
\text { ки, опыт и ценности. Внутриорганизационная структура состо- } \\
\text { ит из переменных, к которым относятся цели, задачи, модели, } \\
\text { технологии, компьютерные и административные системы. }\end{array}$ \\
\hline $\begin{array}{l}\text { Ф. Ферсон, } \\
\text { С. Пайк } \\
{[26]}\end{array}$ & $\begin{array}{l}\text { Новое поле создания стоимости в экономике - это «так называ- } \\
\text { емая неосязаемая сфера, или сфера интеллектуального капита- } \\
\text { ла». } \\
\text { Интеллектуальный капитал - это знание, которое можно кон- } \\
\text { вертировать в стоимость. }\end{array}$ \\
\hline
\end{tabular}

Расхождение взглядов исследователей в определении понятия интеллектуальный капитал также можно наблюдать в вопросе соотнесения понятий «человеческий капитал» и «интеллектуальный капитал». Существует два основных подхода. Согласно первому, интеллектуальный капитал представляет элемент человеческого капитала, и возникновение его происходит в процессе особой сферы обмена деятельностью, связанной с самостоятельным принятием решений в ходе выполнения различных производственных функций [28].

В другом подходе понятие «интеллектуальный капитал» раскрывается через анализ понятий «трудовой потенциал», «человеческий потенциал» и «человеческий капитал». Рассмотрим понятие «интеллектуальный капитал», характеризуя его через определение совокупности понятий «интеллект» и «капитал». В энциклопедиче- 
ских и толковых словарях понятие «интеллект» определяется как умственное начало человека, способность к мышлению, рациональному познанию, способность развития умственных способностей. Наиболее общее определение интеллекта звучит как «общая способность к познанию и решению трудностей, которая объединяет все познавательные способности человека: ощущение, восприятие, память, представление, мышление, воображение» [29]. Если при определении понятия «интеллект» научное сообщество едино в трактовке, то понятие «капитал» в зависимости от рассмотрения его различными экономическими школами на различных исторических этапах развития производства, промышленности и торговли имеет разного рода значение. Так, в классической политической экономической школе понятие «капитал» определяется как используемые для производства товаров и услуг средства производства: машины, оборудование, здания, сооружения. К. Маркс, в свою очередь, вкладывал другое значение в понятие «капитал». По его мнению, средство труда может стать капиталом только тогда, когда его владельцы напрямую или косвенно вступят в экономические отношения с владельцами рабочей силы: «капитал возникает лишь там, где владелец средств производства и жизненных средств находит на рынке свободного рабочего в качестве продавца своей рабочей силы» [30].

В исследованиях И. Фишера капитал рассматривается как дисконтированный доход [31]. В теориях бухгалтерского учета и финансового анализа капитал рассматривается как совокупность материальных ценностей и денежных средств, финансовых вложений и затрат на приобретение прав и привилегий, необходимых для осуществления хозяйственной деятельности организаций. Прослеживая периодизацию взглядов исследователей на определение понятия «капитал», необходимо отметить расширение трактовки понятия от рассмотрения капитала как средства платежа и накопления до рассмотрения капитала в качестве капитала объекта, способного приносить доход. Современная трактовка понятия «капитал» отра- 
жается в трудах В. А. Супруна: «капитал - это инвестированный общественный труд, который в процессе непрерывного движения порождает доход» [38].

В контексте нашего исследования будем рассматривать более широкое определения понятия «капитал» и определим его как инвестиционный ресурс, создающий добавочную стоимость. Синтезируя категории «интеллект» и «капитал», определим понятие интеллектуальный капитал как совокупность интеллектуальных способностей и практических навыков, полученных в процессе обучения и практической деятельности, которые становятся источником дохода.

Основываясь на вышеизложенном, будет верным утверждение, что понятие «интеллектуальный капитал» шире, чем «человеческий капитал», поскольку доход человеку, организации, экономике, в общем, могут приносить не только и не столько сами знания, навыки, творческие способности и моральные ценности. Также важно рассматривать доход, приобретаемый за счет использования патентов и товарных знаков, бизнес-процессов, бренда, положительного имиджа организации и т.д., то есть всего того, что отчасти представляет структурный и клиентский капиталы организации. Рассмотрим понятия интеллектуального капитала как совокупность компонентов.

На сегодняшний день в литературе существуют различные модели и классификации интеллектуальных ресурсов (таблица 2).

Таблица 2. Походы к классификации структуры компонентов интеллектуального капитала

\begin{tabular}{|c|c|c|}
\hline Автор & Внутренний капитал & Внешний капитал \\
\hline $\begin{array}{l}\text { Э. Брукинг } \\
\text { [4] }\end{array}$ & $\begin{array}{l}\text { Человеческие активы (полезные для рабо- } \\
\text { ты умения, знания и компетенции, обра- } \\
\text { зование). } \\
\text { Инфраструктурные активы (активы, вы- } \\
\text { явленные в процессах управления, ин- } \\
\text { формационных и финансовых систем). }\end{array}$ & $\begin{array}{l}\text { Рыночные активы (се- } \\
\text { ти, каналы продаж, } \\
\text { клиенты, бренды) }\end{array}$ \\
\hline
\end{tabular}


Продолжение Таблицы 2

\begin{tabular}{|l|l|l|}
\hline & $\begin{array}{l}\text { Объекты интеллектуальной собственно- } \\
\text { сти (патенты, секреты производства, ли- } \\
\text { цензии и т.д.) }\end{array}$ & \\
\hline Л. Эдвинсон & Человеческий капитал - это комплекс \\
3наний, творческих способностей и прак- & Клиентский капитал \\
тических навыков, служащих на пользу \\
организации и направленных на выполне- \\
ние текущих задач. \\
Структурный капитал - это совокупность \\
организационного капитала и процессно- \\
го
\end{tabular}

Большинство из представленных выше классификаций являются производными модели Свейби-Стюарта-Эдвинссона (SveibyStewart-Edvinsson Model), которая выделяет три типа интеллектуальных ресурсов.

В итоге мы можем наблюдать, что в представленных классификациях интеллектуального капитала организации встречаются общие составляющие, такие как: присутствие человеческого фактора, взаимоотношения с внешней средой (государство, конкуренты, постав- 
щики, клиенты, и пр.) и философия внутренних процессов организации бизнеса. Энни Брукинг в книге «Интеллектуальный капитал: ключ к успеху в новом тысячелетии» рассматривает интеллектуальный капитал как «термин для обозначения нематериальных активов, без которых компания не может существовать» [4]. Э. Брукинг придерживается четырёхкомпонентной классификации интеллектуального капитала (рисунок 3).

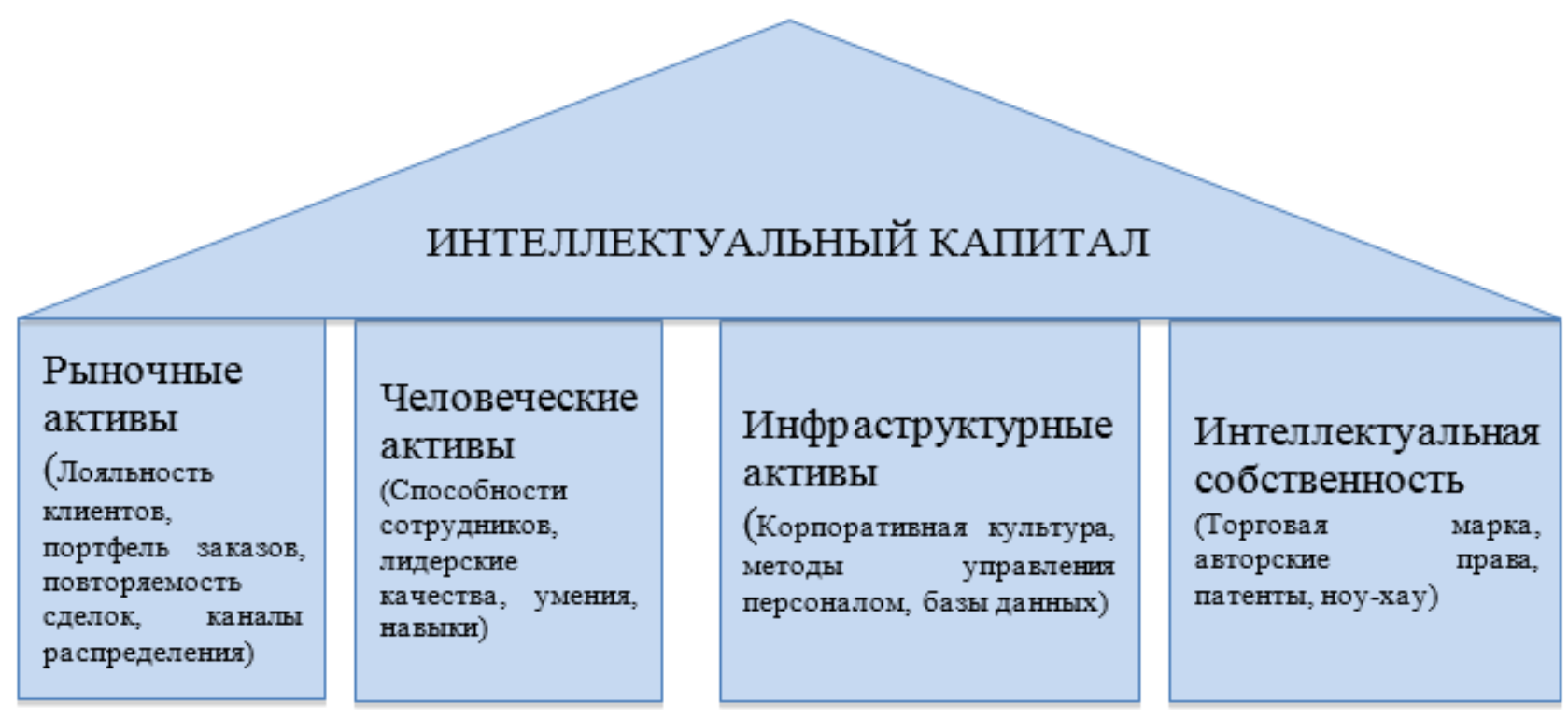

Рисунок 3. Составные части интеллектуального капитала

1) Рыночные активы - это тот потенциал, который обеспечивается нематериальными активами, связанными с рыночными операциями.

2) Человеческие активы - совокупность коллективных знаний сотрудников предприятия, их творческих способностей, умения решать проблемы.

3) Интеллектуальная собственность - инструмент защиты корпоративных активов.

4) Инфраструктурные активы - это технологии, методы и процессы, которые делают работу предприятия возможной.

Представленные выше определения интеллектуального капита- 
ла и классификации относятся к классическому подходу. В современной теории интеллектуальный капитал рассматривается как часть ресурсного портфеля организации (рисунок 4). Именно такой подход используется Й. Руусом, С. Пайком и Л. Фернстремом в работе «Интеллектуальный капитал: практика управления». Они определяют интеллектуальный капитал как «неденежные и нематериальные ресурсы, полностью или частично контролируемые организацией и участвующие в создании ценности» [5].

Весь ресурсный портфель организацин
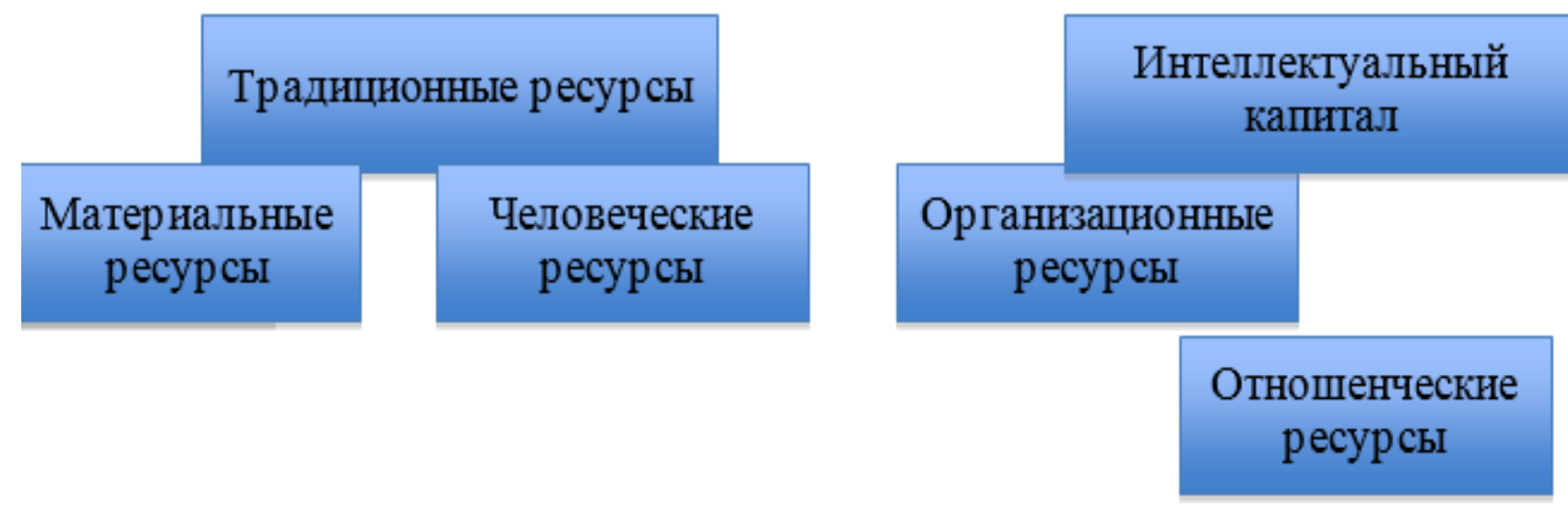

Рисунок 4. Стратегический портфель ресурсов компании [5]

Другие авторы, С. Алберт и К. Бредли, представляют подход, который позволяет видеть в интеллектуальном капитале «процесс превращения знаний и неосязаемых активов в полезные ресурсы» [6]. Они обращают внимание на то, что поведение ресурсов интеллектуального капитала отличается от поведения денежных или материальных ресурсов, а следовательно, и управление ими должно осуществляться по-другому. К свойствам ресурсов интеллектуального капитала авторы относят:

- неаддитивность;

- частичную исключаемость;

- высокий уровень информационной асимметрии в отношении 
как объёма, так и качества (не существует эффективных рынков для торговли этими ресурсами);

- отсутствие состязательности.

К тому же у каждого ресурса интеллектуального капитала разная логика создания ценности, то есть ресурсы интеллектуального капитала обладают разными поведенческими характеристиками. Помимо зарубежных авторов свой вклад в развитие теории интеллектуального капитала внесли и отечественные авторы, такие как Б.Б. Леонтьев, А.И. Колганов и В.Л. Иноземцев. Например, Б.Б. Леонтьев дает следующее определение интеллектуальному капиталу: «стоимость суммы имеющихся у компании интеллектуальных активов, в том числе интеллектуальная собственность, природные и приобретённые навыки и умения сотрудников, базы знаний и полезные отношения с другими субъектами» [7].

Собственный подход к анализу интеллектуального капитала разработали И.В. Ивашковская и Э.Р. Байбурина в своей работе «Роль интеллектуального капитала в создании стоимости российских компаний». Авторы учитывали сложность структуры интеллектуального капитала и рассматривали его на двух уровнях: по компонентам и субкомпонентам [8]. Модель включает следующие элементы:

- Человеческий капитал - совокупность компетенций и способностей персонала.

Организационный капитал.

- Инновационный капитал - совокупность прав интеллектуальной собственности.

- Процессный капитал - инфраструктура компании.

- Клиентский капитал - ценность, заключённая в отношениях с индивидуальными и институциональными клиентами.

- Сетевой капитал - ценность, заключённая в качестве и 
устойчивости отношений с необходимыми контрагентами.

Если рассматривать интеллектуальный капитал как фактор добавленной стоимости, то следует подразумевать совокупность неосязаемых активов, которые оказывают долгосрочное влияние на деятельность компании [9]. Иными словами, материальная стоимость компании зависит во многих случаях от неосязаемых активов, таких как бренд, репутация, отношения с клиентами и так далее.

Добавленная стоимость представляет собой прежде всего разницу между выручкой от реализации продукции (в фактических ценах) и величиной материальных затрат на осуществление процессов производства и реализации. Добавленная стоимость одновременно является экономическим расчетным показателем, который используется для целей оценки и характеристики объемов производства и отражает величину стоимости реализованной продукции, за исключением затрат на использованные в производственном процессе предметы труда.

Показатель «добавленная стоимость» очень важен для предприятия, так как данная категория напрямую зависит от эффективности результатов работы всего предприятия, также добавленная стоимость участвует в формировании доходных статей государственного бюджета, поэтому в ее росте потенциально заинтересованы и государство, и экономические субъекты. Добавленная стоимость включает в себя семь крупных элементов: оплата труда различных категорий работников, отчисления на социальные нужды, амортизационные отчисления на основные средства и нематериальные активы, налоги, включаемые в себестоимость, прочие расходы, потенциальные налоги с реализации, норма прибыли. Каждый из этих структурных элементов добавленной стоимости (за исключением нормы прибыли) также не одноэлементен.

Добавленная стоимость имеет сложную структуру, так как состоит из нескольких элементов, главные из которых представлены на рисунке 5. 


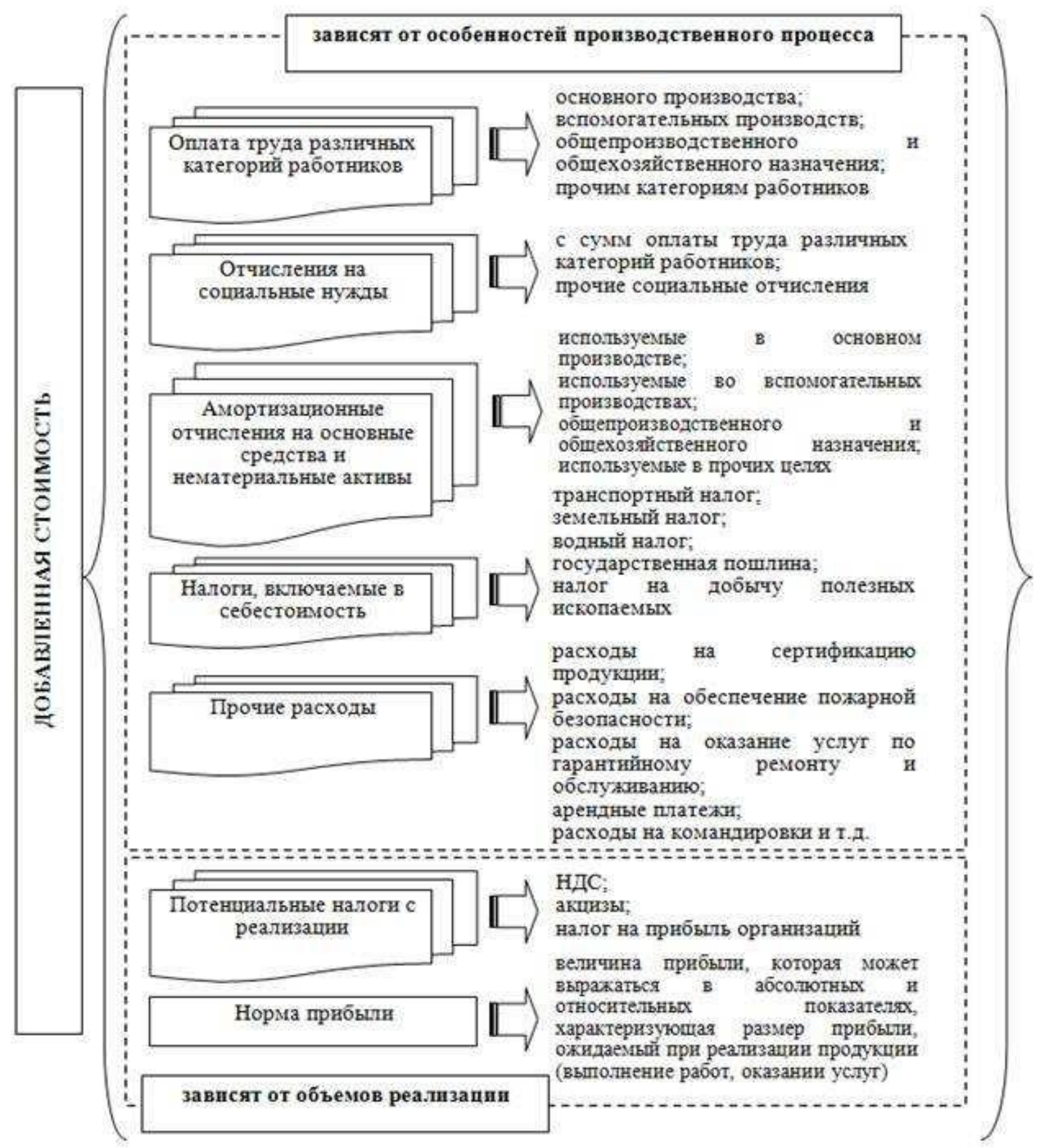

Рисунок 5. Поэлементная структура добавленной стоимости

В ряде исследований «добавленная стоимость рассматривается в качестве показателя интеллектуального капитала, исходя из того, что нормальная экономическая прибыль создается финансовыми и физическими активами, а сверхприбыль - нематериальными ресурсами, имеющимися у компании» [11]. Под интеллектуальной стоимостью понимается стоимость, созданная преимущественно за счет 
внутренней интеграции компонентов интеллектуального капитала [12].

В таблице 3 сведены основные определения интеллектуальной добавленной стоимости.

Таблицуа 3. Определение интеллектуальной добавленной стоимости

\begin{tabular}{|c|c|}
\hline Авторы & $\begin{array}{c}\text { Определение интеллектуальной добавленной } \\
\text { стоимости }\end{array}$ \\
\hline Осколкова М.А. [9] & $\begin{array}{l}\text { интеллектуальная добавленная стоимость - сово- } \\
\text { купность неосязаемых активов, которые оказывают } \\
\text { долгосрочное влияние на деятельность компании }\end{array}$ \\
\hline $\begin{array}{l}\text { Найденова Ю.Н., } \\
\text { Осколкова М.А. [11] }\end{array}$ & $\begin{array}{l}\text { интеллектуальная добавленная стоимость - показа- } \\
\text { тель интеллектуального капитала, исходя из того, } \\
\text { что нормальная экономическая прибыль создается } \\
\text { финансовыми и физическими активами, а сверх- } \\
\text { прибыль - нематериальными ресурсами, имеющи- } \\
\text { мися у компании }\end{array}$ \\
\hline $\begin{array}{l}\text { Головко Т.В., } \\
\text { Байбурина Э.Р. [12] }\end{array}$ & $\begin{array}{l}\text { интеллектуальная добавленная стоимость - стои- } \\
\text { мость, созданная преимущественно за счет внут- } \\
\text { ренней интеграции компонентов интеллектуально- } \\
\text { го капитала }\end{array}$ \\
\hline
\end{tabular}

При рассмотрении интеллектуального капитала как фактора добавленной стоимости исследователь вынужден иметь дело с определенными объективными трудностями. По мнению А. Гапоненко, к их числу следует отнести:

- Неосязаемость. Интеллектуальный капитал не поддается тактильному восприятию.

- Эффект значительных временных задержек. Для получения эффекта от больших инвестиций в интеллектуальный капитал необходимо время, то есть существует временной лаг, который откладывает момент получения выгод от инвестиции.

- Эффект с ненулевой суммой. Данная проблема заключается в том, что потоки, которые связаны с интеллектуальным капиталом, не 
всегда суммируются с нулем. Это значит, что инвестиции в разработку новых информационных систем могут не оправдаться, если информационные системы не подходят для данной компании.

- Закон возрастающей предельной отдачи: «в то время как земля, капитал и труд следуют закону убывающей отдачи, знания и информация имеют возрастающую отдачу, т.е. созданная с помощью данных компонентов стоимость растет по мере увеличения применяемого и генерируемого интеллектуального капитала».

В литературе, посвящённой интеллектуальному капиталу, часто встречается множество синонимов, таких как интеллектуальная собственность, интеллектуальные активы, нематериальные активы. Однако некоторые из этих определений более узкие и описывают лишь часть того, что включает в себя интеллектуальный капитал. Если обратиться к Гражданскому кодексу РФ, то согласно статье 1225 ГК интеллектуальная собственность - это охраняемые законом результаты интеллектуальной деятельности и средства индивидуализации [15]. Отсюда видно, что определение не включает в себя опыт и навыки работников или базы данных компании.

Большинство акционеров используют термины «нематериальные активы» и «интеллектуальный капитал» как взаимозаменяемые. Действующее в РФ Положение по бухгалтерскому учету «Учет нематериальных активов» (ПБУ 14/2007) говорит нам о том, что «нематериальными активами не являются: расходы, связанные с образованием юридического лица (организационные расходы); интеллектуальные и деловые качества персонала организации, их квалификация и способность к труду» [16]. Это свидетельствует о том, что определение нематериальных активов тоже более узкое, чем сам интеллектуальный капитал. Интеллектуальный капитал включает в себя нематериальные активы, но помимо этого отражает также другие ключевые качественные характеристики, описывающие текущее состояние компании и позволяющие оценить ее будущий потенциал развития [17]. Многие акционеры считают, что ресурсы интеллектуально- 
го капитала являются второразрядными, поэтому убедить инвестировать в них сложно, также непросто выработать по отношению к ним согласованные стратегии.

Существует множество ресурсов интеллектуального капитала, имеющих материальное выражение. Точно так же существует большое количество традиционных экономических ресурсов, имеющих нематериальное выражение. Способность управлять ресурсами интеллектуального капитала комплексно и последовательно является определяющим моментом в процессе создания акционерной ценности для многих крупнейших фирм.

Итак, в современной экономической науке не существует консенсуса в определении как интеллектуального капитала, так и интеллектуальной добавленной стоимости. Вместе с тем все существующие подходы содержат общую идею: интеллектуальный капитал это что-то важное и полезное для фирмы, основанное на знаниях, не имеющее материальной формы. Эта общность становится основанием для единства используемых классификаций, поскольку практически в каждой из них присутствует человеческий и структурный капитал. Именно интеллектуальный капитал, являясь жизненно необходимым для организации, представляет собой ее фундамент и то, на чем любая фирма держится - люди, их опыт и знания, взаимодействия между ними и т.д.

В рамках исследования под интеллектуальной добавленной стоимостью мы будем понимать стоимость, созданную благодаря интеллектуальному капиталу и охватывающую его реальный вклад в создание стоимости конкретного продукта, опираясь на классификацию элементов по Т. Стюарту. Данное направление исследования интеллектуального капитала в настоящее время является очень важным, поскольку для компаний и учёных приоритетными становятся вопросы о том, как и в какой степени интеллектуальный капитал влияет на деятельность компании и чего можно добиться, обладая 
таким знанием, чтобы улучшить ее финансовые показатели.

\section{2. Методики измерения интеллектуальной добавленной стоимости на предприятии}

Наличие у предприятия интеллектуальных ресурсов определяет его способности к устойчивому и конкурентоспособному развитию. Совокупность знаний, умений и навыков, в том числе сформированных в нематериальные и прочие активы, рассматриваются как интеллектуальный капитал предприятия.

Эмпирически наличие интеллектуального капитала у предприятия можно идентифицировать через его успешность на рынке и способность формировать высокую добавленную стоимость в продукте. Однако с научно-методической точки зрения подходы к оценке интеллектуального капитала в настоящее время не являются унифицированными и не позволяют получить объективную стоимостную оценку этого капитала.

В данном параграфе представлены методики измерения интеллектуальной добавленной стоимости на предприятии и показаны проблемы использования этих методик в аналитических процедурах.

На сегодняшний день существует 42 метода для измерения неосязаемых активов, но ни один метод не может в полной мере оценить интеллектуальный капитал.

В научной литературе выделяют два подхода к измерению интеллектуального капитала:

1. Структурный подход - основанный на выделении составляющих интеллектуального капитала (часто нефинансовые методы).

2. Стоимостной подход - агрегированная оценка стоимости интеллектуального капитала. 
Рассмотрим более подробно стоимостные методы измерения, которые определяют уровень развития интеллектуального капитала по некоторому интегральному признаку. Рассмотрим основные.

Коэффищиент $Q$-Тобина - это отношение между рыночной и балансовой стоимостью активов компании. Данный показатель используется в классической теории инвестиций. Изменение этого коэффициента косвенно отражает эффективность использования интеллектуального капитала компании.

Экономическая добавленная стоимость (Economic Value Added, EVA) - метод оценки экономической прибыли. Рассчитывается путем корректировки, опубликованной прибыли фирм с учётом издержек, связанных с нематериальными ресурсами. Изменение EVA свидетельствует о том, производителен ли интеллектуальный капитал или нет.

Рыночная добавленная стоимость (Market Value Added, MVA) - рыночная стоимость компании за вычетом восстановительной стоимости ее активов. Если компания эффективно использует свой интеллектуальный капитал, то имеет положительную разницу.

Оиенённая стоимость неосязаемых активов (Calculated Intagibles Value, CIV) - рассчитывает избыточную доходность материальных активов, а затем использует этот показатель в качестве основы для определения доли дохода, приходящегося на нематериальные активы.

Интеллектуальный коэффициент добавленной стоимости (Value Added Intellectual Coefficient, VAIC) - измеряет вклад материальных и нематериальных активов в добавленную стоимость компании. Также этот метод показывает насколько эффективно интеллектуальный капитал создает ценность фирме на основе трех главных компонентов: физического капитала, человеческого и структурного капитала. 
Для измерения вклада интеллектуальной добавленной стоимости на предприятии используется метод VAIC (Value added intellectual coefficient), также его использует большинство авторов для проведения эмпирических исследований. Метод VAIC относится к стоимостным методам измерения, которые определяют уровень развития интеллектуального капитала по некоторому интегральному признаку.

Термин «интеллектуальная добавленная стоимость» в английском варианте находится в качестве методики VAIC (является зарегистрированной торговой маркой). Использование метода VAIC обладает рядом преимуществ:

подход может быть применён к любым компаниям, независимо от размера;

вычисления, используемые в рамках VAIC, достаточно просты;

результаты будут понятны даже тем, кто не обладает глубокими знаниями в области бухгалтерского учета;

результаты измерения с помощьюVAIC можно использовать для сравнения предприятий в разных отраслях;

общепринятое определение интеллектуального капитала и его трактовка в рамках подхода VAIC сопоставимы, что делает этот метод подходящим для измерения результатов любой компании;

данный показатель может быть рассчитан на основе данных бухгалтерской отчетности банка.

Вместе с тем этот метод не лишен недостатков, среди которых выделим два:

метод нельзя использовать для прогнозирования, так как он опирается на текущие финансовые показатели;

данные бухгалтерской отчётности не учитывают особые 
свойства интеллектуального капитала.

Интеллектуальный коэффициент добавленной стоимости был впервые предложен Анте Пулик в 1997 году. Интеллектуальный коэффициент добавленной стоимости позволяет компаниям определить вклад в добавленную стоимость, с одной стороны, материальных активов, а с другой стороны, нематериальных активов. Чем лучше компания использует потенциал, тем выше интеллектуальный коэффициент добавленной стоимости данной компании [1]. Модель интеллектуального коэффициента добавленной стоимости (VAIC) определяет эффективность использования трех основных типов ресурсов фирмы, а именно: добавленной стоимости физического капитала (CEE), добавленной стоимости человеческого капитала (HCE) и добавленной стоимости структурного капитала (SCE). Их сумма составляет значение интеллектуального коэффициента добавленной стоимости (VAIC). Чем больше этот показатель, тем выше оценивается потенциал фирмы, ее способность создавать добавленную стоимость.

Формула коэффициента выглядит следующим образом:

$$
\mathrm{VAIC}=\mathrm{HCE}+\mathrm{SCE}+\mathrm{CEE},
$$

где НСЕ показывает то, насколько эффективно используется человеческий капитал или вклад человеческого капитала в добавленную стоимость. Равен отношению добавленной стоимости и затрат на труд;

SCE показывает то, насколько эффективно используется организационный капитал, иначе говоря, вклад организационного капитала в добавленную стоимость. Равен отношению добавленной стоимости за вычетом человеческого капитала и добавленной стоимостью;

СЕЕ показывает то, насколько эффективно используется задействованный капитала или вклад задействованного капитала в добав- 
ленную стоимость. Определяется делением добавленной стоимости на инвестированный капитал.

Добавленная стоимость может быть получена как разность между выручкой и материальными затратами за исключением затрат на труд.

Однако многие исследователи приводят оценку интеллектуального капитала как результат следующих шести шагов:

1. Рассчитывается добавленная стоимость компании.

$$
\mathrm{VA}=\text { Output }- \text { Input, }
$$

где VA - добавленная стоимость; Output - общий доход; Input - стоимость купленного материала, сервиса.

Кроме этого, добавленная стоимость может быть рассчитана как:

$$
\mathrm{VA}=\mathrm{R}+\mathrm{DD}+\mathrm{T}+\mathrm{EC}+\mathrm{D}+\mathrm{A},
$$

где R - нераспределенная прибыль; DD - дивиденды; T- налоги; $\mathrm{EC}$ - общие расходы рабочих; D + A - обесценение и амортизация.

2. Рассчитывается эффективность человеческого капитала.

Согласно данной методологии человеческий капитал может быть рассчитан как «расходы на оплату труда».

$$
\mathrm{HCE}=\mathrm{VA} / \mathrm{HC} \text {, }
$$

где НСЕ - эффективность человеческого капитала; VA - добавленная стоимость; НС - человеческий капитал.

3. Рассчитывается эффективность структурного капитала.

$$
\mathrm{SC}=\mathrm{VA}-\mathrm{HC}
$$

где SC - структурный капитал; VA - добавленная стоимость; НC человеческий капитал. SC и НC обратно пропорциональны VA. Далее определяем эффективность структурного капитала: 


$$
\mathrm{SCE}=\mathrm{SC} / \mathrm{VA},
$$

где SCE - эффективность структурного капитала; SC - структурный капитал; VA - добавленная стоимость.

4. Рассчитывается эффективность интеллектуального капитала.

Эффективность интеллектуального капитала получается благодаря суммированию эффективности человеческого и эффективности структурного капитала:

$$
\mathrm{ICE}=\mathrm{HCE}+\mathrm{SCE} .
$$

5. Рассчитывается эффективность задействованного капитала.

$$
\mathrm{CEE}=\mathrm{VA} / \mathrm{CE}
$$

где СЕЕ - эффективность задействованного капитала; VA - добавленная стоимость; СЕ - балансовая стоимость чистых материальных активов компании.

6. Рассчитывается VAIC следующим образом:

$$
\mathrm{VAIC}=\mathrm{ICE}+\mathrm{CEE} \text {. }
$$

Важно отметить, что расчет данного коэффициента имеет ряд особенностей:

- Человеческий и организационный капитал находятся по отношению друг к другу в обратной зависимости, то есть чем больше добавленной стоимости создает человеческий капитал, тем меньше ее создает структурный. Верным является и обратное утверждение.

Стоимость рабочей силы не включается в затраты при расчете добавленной стоимости.

Достоинства метода заключаются в простоте оценки и доступности данных. Однако использование бухгалтерской отчетности означает, что не учитываются определенные свойства интеллектуального капитала, а также будущая деятельность компании. 


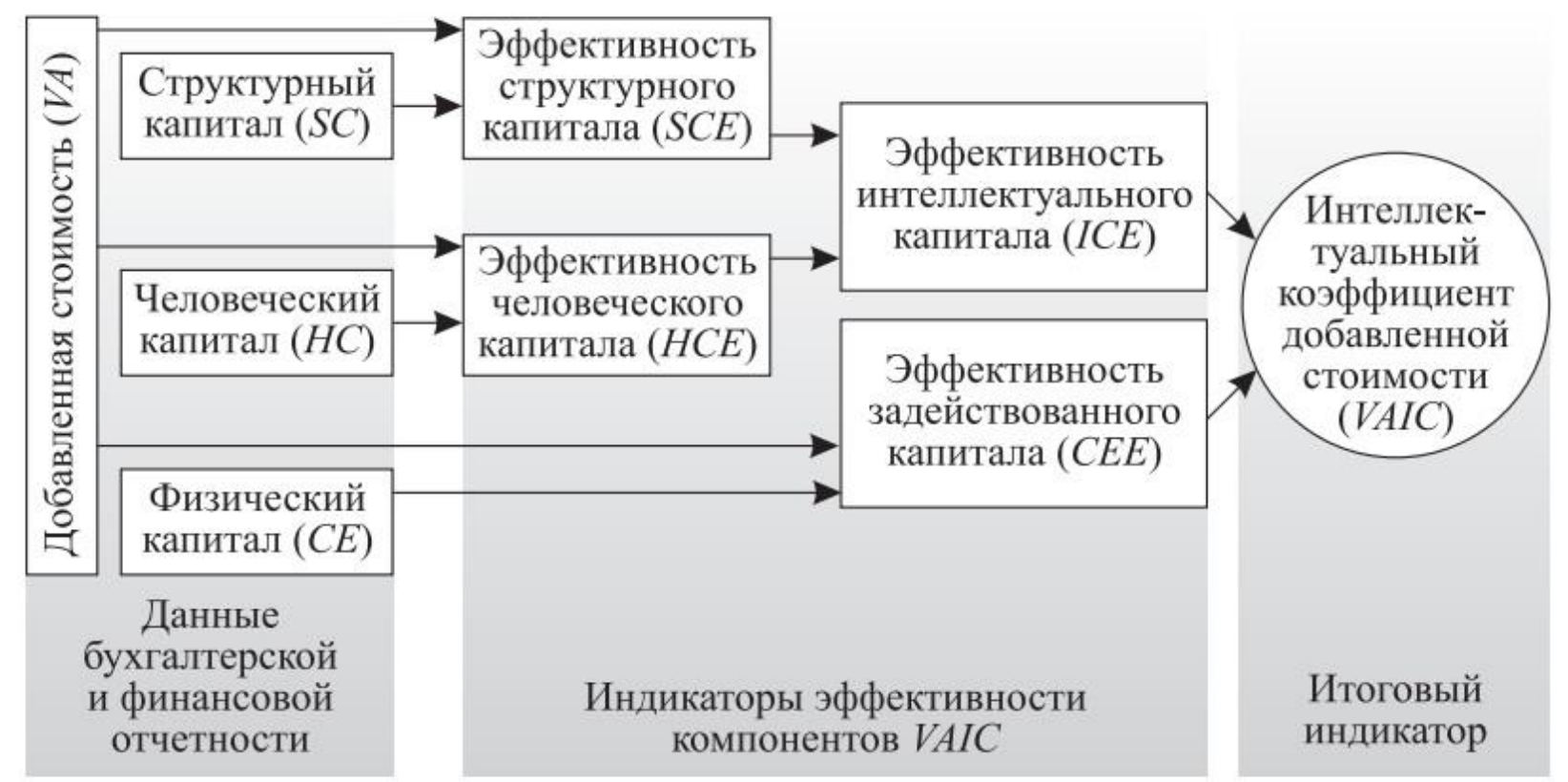

Рисунок 6. Метод расчета VAIC [18]

Для моделирования влияния интеллектуального капитала на результаты деятельности компании метод VAIC используют в качестве независимой переменной, отражающей уровень интеллектуального капитала компании. В качестве зависимых переменных, как отмечалось, исследователи выбирают рыночную стоимость компании, производительность труда, темп роста выручки, рентабельность активов и др. Анализ работ показывает, что многие исследователи дополняют метод VAIC другими компонентами интеллектуального капитала. Так, Чен с соавторами [19] критикуют Пулика за то, что структурный капитал, рассчитанный по его формуле, не учитывает инновационный капитал, дополняют тестируемую модель расходами на НИОКР, эмпирически доказывая, что объясняющая способность регрессионной модели улучшается.

Метод VAIC позволяет также анализировать покомпонентное влияние интеллектуального и физического капитала на результаты деятельности компании. На примере компаний Южной Африки и Гонконга эмпирически было доказано большее влияние физического капитала, измеренного через СЕE, на результаты деятельности ком- 
пании по сравнению с интеллектуальным капиталом, измеренным посредством ICE (или отдельных компонентов - человеческого (HCE) и структурного (SCE) капиталов).

В настоящее время существует несколько эмпирических исследований по данному направлению. Представленные работы (таблица 4) отличаются друг от друга как по используемым данным, так и по временным периодам. Однако можно отметить общие гипотезы, которые подтвердились в большинстве работ по результатам эмпирических исследований:

- существует положительная связь между уровнем интеллектуального капитала и результатами деятельности компании;

- существует взаимное влияние отдельных компонентов интеллектуального капитала;

- существует незначимость отдельных элементов, в особенности человеческого капитала, без наличия остальных.

Таблицуа 4. Зарубежные исследования интеллектуального капитала методом VAIC

\begin{tabular}{|c|c|c|}
\hline $\begin{array}{c}\text { Название статьи, } \\
\text { авторы }\end{array}$ & $\begin{array}{c}\text { Информаци- } \\
\text { онная база }\end{array}$ & Результаты исследования \\
\hline $\begin{array}{l}\text { Intellectual capital and } \\
\text { traditional measures of } \\
\text { corporate performance } \\
\text { (Steven Firer, } \\
\text { S. Mitchel Williams) } \\
2003\end{array}$ & $\begin{array}{l}75 \text { публичных } \\
\text { компаний } \\
\text { Южной Аф- } \\
\text { рики, данные } \\
2011 \text { года }\end{array}$ & $\begin{array}{l}\text { Эмпирические результаты не показа- } \\
\text { ли сильную связь между компонента- } \\
\text { ми ИК и результатами деятельности } \\
\text { компании. Однако технологические } \\
\text { достижения в разных регионах стран } \\
\text { с развивающейся экономикой могут } \\
\text { иметь неодинаковые последствия для } \\
\text { интеллектуального капитала в созда- } \\
\text { нии стоимости компании и повыше- } \\
\text { ния фин. эффективности. }\end{array}$ \\
\hline
\end{tabular}

${ }^{1}$ Составлено авторами по [20-32]. 
Продолжение Таблицы 4

\begin{tabular}{|c|c|c|}
\hline $\begin{array}{l}\text { VAIC - an accounting } \\
\text { tool for IC manage- } \\
\text { ment } \\
\text { (A.Pulic) } 2000\end{array}$ & $\begin{array}{l}30 \text { компаний } \\
\text { 1992-1999 }\end{array}$ & $\begin{array}{l}\text { Выявлена положительная связь меж- } \\
\text { ду уровнем интеллектуального капи- } \\
\text { тала и рыночной стоимостью компа- } \\
\text { нии. }\end{array}$ \\
\hline $\begin{array}{l}\text { Knowledge manage- } \\
\text { ment in the manufac- } \\
\text { turing industry } \\
\text { (E. Kremp, J. Mair- } \\
\text { esse) } 2002\end{array}$ & $\begin{array}{l}\text { Более } 5 \text { тысяч } \\
\text { французских } \\
\text { предприятий }\end{array}$ & $\begin{array}{l}\text { При увеличении интенсивности } \\
\text { управления знаниями на 1\% произ- } \\
\text { водительность труда увеличивается } \\
\text { на } 3 \% .\end{array}$ \\
\hline $\begin{array}{l}\text { An empirical investi- } \\
\text { gation of the relation- } \\
\text { ship between intellec- } \\
\text { tual capital and firms' } \\
\text { market value and fi- } \\
\text { nancial performance } \\
\text { (Ming-Chin Chen, } \\
\text { Shu-Ju Cheng, } \\
\text { Yuhchang Hwang) } \\
2005\end{array}$ & $\begin{array}{l}\text { Публичные } \\
\text { компании } \\
\text { Тайваня } \\
1992-2002 \text { го- } \\
\text { дов } \\
4254 \text { фирм-лет }\end{array}$ & $\begin{array}{l}\text { Будущая рентабельность, рост дохо- } \\
\text { дов и производительность сотрудни- } \\
\text { ков зависят от эффективности ИК, a } \\
\text { R\&D расходы имеют важное значе- } \\
\text { ние для будущей доходности фирм. }\end{array}$ \\
\hline $\begin{array}{l}\text { Intellectual Capital } \\
\text { and financial returns } \\
\text { of companies } \\
\text { (Hong Pew Tan, Da- } \\
\text { vid Plowman and Phil } \\
\text { Hancock) } 2007\end{array}$ & $\begin{array}{l}\text { Данные } \\
\text { 2000-2002 } \\
\text { годов } \\
150 \text { публич- } \\
\text { ных компаний } \\
\text { Сингапура }\end{array}$ & $\begin{array}{l}\text { Положительная связь между ИК } \\
\text { компаний и их деятельностью для } \\
\text { трёх лет. Также подтверждается ги- } \\
\text { потеза о том, что чем выше ценность } \\
\text { ИК в компании, тем выше ее буду- } \\
\text { щие показатели. Это обьясняет по- } \\
\text { ложительную связь между степенью } \\
\text { роста ИК компании и будущих пока- } \\
\text { зателей компании. Вклад ИК в стои- } \\
\text { мость компании зависит от отрасли. }\end{array}$ \\
\hline $\begin{array}{l}\text { Intellectual Capital } \\
\text { and Firm Performance } \\
\text { in Australia } \\
\text { (Martin Clarke, Dyna } \\
\text { Seng and Rosalind H. } \\
\text { Whiting) } 2010\end{array}$ & $\begin{array}{l}2161 \text { публич- } \\
\text { ных компаний } \\
\text { Австралии } \\
\text { 2003-2008 } \\
\text { годы }\end{array}$ & $\begin{array}{l}\text { Полученные результаты свидетель- } \\
\text { ствуют о том, что есть прямая связь } \\
\text { между ИК и производительностью } \\
\text { перечисленных фирм с эффективно- } \\
\text { стью человеческого капитала. Поло- } \\
\text { жительная связь между элементами } \\
\text { ИК (человеческий и структурный }\end{array}$ \\
\hline
\end{tabular}


Продолжение Таблицы 4

\begin{tabular}{|c|c|c|}
\hline & & $\begin{array}{l}\text { капитал). Данные также указывают } \\
\text { на возможность слабой связи между } \\
\text { ИК и финансовым капиталом, кото- } \\
\text { рый влияет на эффективность дея- } \\
\text { тельности предприятий. }\end{array}$ \\
\hline $\begin{array}{l}\text { Intellectual capital and } \\
\text { company value } \\
\text { (Irina Berzkalne, Elv- } \\
\text { ira Zelgalve) } 2013\end{array}$ & $\begin{array}{l}64 \text { публичных } \\
\text { балтийских } \\
\text { компаний } \\
2005-2011 \\
\text { годы }\end{array}$ & $\begin{array}{l}\text { Увеличение интеллектуального ка- } \\
\text { питала приводит к увеличению сто- } \\
\text { имости компании. Существует ста- } \\
\text { тистически значимая и положитель- } \\
\text { ная связь между интеллектуальным } \\
\text { капиталом и стоимостью компании } \\
\text { для предприятий в Латвии и Литве, } \\
\text { в то время как такая связь не наблю- } \\
\text { дается для компаний в Эстонии. Ре- } \\
\text { зультаты этого исследования пока- } \\
\text { зывают, что эффективность челове- } \\
\text { ческого капитала и инвестированно- } \\
\text { го капитала может до сих пор ис- } \\
\text { пользоваться для расчета интеллек- } \\
\text { туального капитала, однако струк- } \\
\text { турный капитал не является суще- } \\
\text { ственным в случае интеллектуально- } \\
\text { го капитала и стоимости компании. }\end{array}$ \\
\hline $\begin{array}{l}\text { Intellectual Capital } \\
\text { and Financial Perfor- } \\
\text { mance of Pharmaceu- } \\
\text { tical Firms in Pakistan } \\
\text { (Shahid Amin, Shoaib } \\
\text { Aslam) } 2014\end{array}$ & $\begin{array}{l}\text { Фармацевти- } \\
\text { ческие пред- } \\
\text { приятия Па- } \\
\text { кистана }\end{array}$ & $\begin{array}{l}\text { Выявлена статистическая незначи- } \\
\text { мость влияния ИК на финансовые } \\
\text { показатели фармацевтических ком- } \\
\text { паний. Но из трех компонентов ИК } \\
\text { человеческий и физический капитал } \\
\text { наиболее значимые. }\end{array}$ \\
\hline
\end{tabular}

В России также проводились исследования по интеллектуальному капиталу методом VAIC, но их количество намного меньше, нежели зарубежных исследований (таблица 5). 
Таблица 5. Отечественные исследования интеллектуального капитала методом VAIC

\begin{tabular}{|c|c|c|}
\hline $\begin{array}{c}\text { Название статьи, } \\
\text { авторы }\end{array}$ & $\begin{array}{c}\text { Информационная } \\
\text { база } \\
\end{array}$ & Результаты исследования \\
\hline $\begin{array}{l}\text { Влияние интеллекту- } \\
\text { ального капитала на } \\
\text { результаты деятель- } \\
\text { ности компании } \\
\text { (А.А. Быкова и } \\
\text { М.А. Молодчик) } \\
2011\end{array}$ & $\begin{array}{l}401 \text { предприятие } \\
\text { Пермского края } \\
\text { 2005-2007 годы }\end{array}$ & $\begin{array}{l}\text { Статистическая значимость мо- } \\
\text { делей на 1\% уровне. Положи- } \\
\text { тельная связь между уровнем } \\
\text { интеллектуального капитала и } \\
\text { темпом роста выручки не зави- } \\
\text { сит от отрасли. }\end{array}$ \\
\hline $\begin{array}{l}\text { Влияние интеллекту- } \\
\text { ального капитала на } \\
\text { результаты деятель- } \\
\text { ности российских } \\
\text { производственных } \\
\text { компаний } \\
\text { (Андреева Т., Гага- } \\
\text { рина Т.) } 2017 \\
\end{array}$ & $\begin{array}{l}240 \text { российских } \\
\text { производственных } \\
\text { компаний }\end{array}$ & $\begin{array}{l}\text { Выявлена положительная связь } \\
\text { показателей деятельности ком- } \\
\text { паний с организационным и че- } \\
\text { ловеческим капиталом и ее от- } \\
\text { сутствии - с капиталом отно- } \\
\text { шенческим, это можно объяс- } \\
\text { нить спецификой производ- } \\
\text { ственного сектора }\end{array}$ \\
\hline $\begin{array}{l}\text { Особенности оценки } \\
\text { интеллектуального } \\
\text { капитала энергетиче- } \\
\text { ских компаний } \\
\text { (Н.В. Клочкова, } \\
\text { Е.Е. Беляева) } 2014\end{array}$ & $\begin{array}{l}\text { Энергетическая } \\
\text { отрасль, на приме- } \\
\text { ре компании ОАО } \\
\text { «МРСК Центра и } \\
\text { Приволжья» }\end{array}$ & $\begin{array}{l}\text { Предложенная модель оценки } \\
\text { интеллектуального капитала } \\
\text { энергетической компании и } \\
\text { результаты ее апробации поз- } \\
\text { воляют использовать их при } \\
\text { построении систем монито- } \\
\text { ринга и контроля процессов } \\
\text { инновационного развития } \\
\text { компании. }\end{array}$ \\
\hline $\begin{array}{l}\text { Измерение интеллек- } \\
\text { туального капитала } \\
\text { компаний ресторан- } \\
\text { но-гостиничного } \\
\text { бизнеса с помощью } \\
\text { метода VAIC (Ширя- } \\
\text { ева М.А., Шулятье- } \\
\text { ва Ю.Д.) } 2014\end{array}$ & $\begin{array}{l}109 \text { предприятий } \\
\text { ресторанно- } \\
\text { гостиничного биз- } \\
\text { неса }\end{array}$ & $\begin{array}{l}\text { Выявлено неоднозначное вли- } \\
\text { яние внедрения корпоратив- } \\
\text { ной культуры на функциони- } \\
\text { рование компаний }\end{array}$ \\
\hline
\end{tabular}


Продолжение Таблицы 5

\begin{tabular}{|l|l|l|}
\hline Интеллектуальный & 15 предприятий & Выявлена тесная корреляци- \\
капитал и рентабель- & Пермского & онная зависимость между \\
ность предприятия: & края за 2010 год, & структурными элементами \\
характеристика и & находящихся на & интеллектуального капитала и \\
оценка (Томчук Д., & сходных позициях & показателем рентабельности \\
Перский Ю., Сево- & в своей конкурент- \\
дина В.) 2013 & пой среде & \\
\hline
\end{tabular}

Немногочисленность работ по данной теме в России объясняется доминирующей ролью материальных активов по сравнению с нематериальными активами. При формировании стоимости компании существуют также сложности технического характера: отличные от Международных стандартов финансовой отчётности стандарты бухгалтерской отчетности, а также недостаточное внедрение современных показателей для большинства российских компаний, таких как соотношение рыночной и балансовой стоимости (MBV, Market-toBook-Value), экономическая добавленная стоимость (EVA, Economic Value Added) в систему финансовой отчетности.

Итак, на сегодняшний день существует 42 метода измерения интеллектуального капитала организации, однако с научнометодической точки зрения данные методы не позволяют получить объективную оценку интеллектуального капитала. В монографии для эмпирической части мы будем использовать метод VAIC, автором которого является Анте Пулик, так как он используется для измерения интеллектуальной добавленной стоимости на предприятии, также его использует большинство авторов для проведения эмпирических исследований. В данном параграфе рассмотрены достоинства и недостатки данного метода оценки интеллектуального капитала, одно из главных достоинств данного метода заключается в простоте оценки и доступности данных. 


\section{3. Стратегические модели управления созданием интеллектуальной добавленной стоимости}

В мировой практике в последнее время получило широкое распространение «интеллектуальная организация», то есть организация, рассматривающая в качестве основной стратегии развития стратегию управления интеллектуальным капиталом.

В данном параграфе рассматривается роль интеллектуального капитала организации и его компонентов в сложном процессе создания интеллектуальной стоимости компании. Компоненты интеллектуального капитала составляют систему факторов стоимости компании нематериальной природы, развитие которых наряду с финансовыми активами приводит к достижению устойчивых конкурентных преимуществ, росту стоимости бизнеса. Развитие конкурентоспособности предприятия приобретает особое значение в рыночных условиях. Развитие экономики за последние года характеризуется обострением конкурентной борьбы во многих отраслях и сферах деятельности.

Интеллектуальный капитал в настоящее время стремительно развивается и становится основным источником инновационного развития и экономической конкурентоспособности компаний. Интеллектуальный капитал в настоящее время стремительно развивается и становится основным источником инновационного развития и экономической конкурентоспособности компаний, представляя собой сумму знаний всех работников компании и инструментов организации, увеличивающих стоимость компании.

Стратегическое управление интеллектуальным капиталом для создания интеллектуальной добавленной стоимости предприятия является одним из наиболее перспективных методов в формировании целей и задач, способствующих развитию организации. В настоящее время применяется несколько основных типов стратегий управления интеллектуальным капиталом, которые позволяют сформировать его 
и использовать для повышения конкурентоспособности организации. Они направлены на создание новой стоимости, реализованной в продуктах, людях и процессах с помощью рационального формирования и использования знаний в организации.

«Интеллектуальный капитал» определяется как сумма знаний всех работников компании, обеспечивающих ее конкурентоспособность [5]. Однако понятия «знания» и «интеллектуальный капитал» не равнозначны, так как знаний еще не достаточно для повышения прибыльности, также необходимы: соответствующая организация труда, инфраструктурная поддержка (системы передачи и хранения информации) и наличие спроса на имеющиеся у компании знания, то есть клиенты [33].

В интеллектуальный капитал включают все знания и навыки, явные и неявные, принадлежащие как организации в целом, так и отдельным лицам, а также структурные и культурные элементы. Термин «интеллектуальный актив» закрепляется исключительно за теми видами интеллектуальных ресурсов, которые организации удалось определить, описать, занести в реестр. Интеллектуальный актив - это всегда явное и зафиксированное знание, право собственности на которое принадлежит организации. К интеллектуальной собственности относятся полностью юридически оформленные интеллектуальные активы - патенты, торговые марки и т.д. [34]. Сложность и противоречивость процесса интеллектуализации хозяйственных отношений, а также специфика решения задач интеллектуального внутрикорпоративного воспроизводства обусловливает необходимость уточнения и детализации субъектно-объектной целостности управления интеллектуальным капиталом предприятия. Данная целостность объективно предопределяется «сущностным единством» самого интеллектуального капитала, под которым понимается система актуализированных созидательноинновационных знаний, используемых предприятием для воспроизводства жизненных ценностей [35]. Постоянное формирование и раз- 
витие интеллектуального знания и, следовательно, востребованный процесс сознательного воздействия на динамику создания и использования актуальных корпоративных знаний, начиная с этапа их возникновения и завершая этапами их капитализации и последующей коммерциализации, требуют от специалистов разработки современного инструментария управления интеллектуальным капиталом и инновациями предприятий.

Применяется несколько основных типов стратегий управления интеллектуальным капиталом, которые позволяют сформировать его и использовать в целях повышения конкурентоспособности организации. Они направлены на создание новой стоимости, реализованной в продуктах, людях и процессах с помощью рационального формирования и использования знаний в организации. Выделяют четыре комбинации существующих стратегий.

Гапоненко А.Л. предложил семь стратегий управления интеллектуальным капиталом. Три из них состоят в том, чтобы эффективно формировать и использовать знания в рамках одного из трех видов интеллектуального капитала, еще четыре стратегии можно объединить в одну, так как она предполагает достижение позитивного эффекта от взаимодействия двух различный видов интеллектуального капитала (человеческого и структурного, человеческого и потребительского, структурного и потребительского) [36].

Эффективное управление интеллектуальным капиталом означает воздействие на все его элементы (седьмая стратегия) как совокупность взаимосвязанных частей для достижения наибольшего синергетического эффекта (таблица 6).

Таблища 6. Стратегии управления интеллектуальным капиталом

\begin{tabular}{|l|l|}
\hline Стратегия & \multicolumn{1}{|c|}{ Характеристика } \\
\hline Первая & $\begin{array}{l}\text { Развитие индивидуальной компетенции работников путем их } \\
\text { обучения, проведения тренингов }\end{array}$ \\
\hline
\end{tabular}


Продолжение Таблицы 6

\begin{tabular}{|l|l|l|}
\hline Вторая & $\begin{array}{l}\text { Формирование и использование знаний; информационные } \\
\text { системы, базы данных, оргструктуры, авторские права, } \\
\text { патенты, ноу-хау, лицензии и пр. }\end{array}$ \\
\hline Третья & $\begin{array}{l}\text { Формирование и использование знаний во внешних связях } \\
\text { организации. Стратегия опирается на маркетинговые } \\
\text { технологии. }\end{array}$ \\
\hline Четвертая & $\begin{array}{l}\text { Использование приемов и методов взаимодействия с } \\
\text { потребителями, которые повышают индивидуальную } \\
\text { помпетенцию сотрудников организации. }\end{array}$ \\
\hline Шестая & $\begin{array}{l}\text { Перенос индивидуального знания во внутрикорпоративные } \\
\text { системы и закрепление его там с целью широкого } \\
\text { использования другими сотрудниками. }\end{array}$ \\
\hline $\begin{array}{l}\text { Перенос знаний из сферы взаимодействия с внешними } \\
\text { контрагентами организации во внутрикорпоративные } \\
\text { системы и закрепление их там с целью широкого } \\
\text { использования сотрудниками. }\end{array}$ \\
\hline Седьмая & $\begin{array}{l}\text { Движение знаний одновременно между всеми видами } \\
\text { интеллектуального капитала. }\end{array}$ \\
\hline
\end{tabular}

Первая стратегия основана на формировании и использовании человеческого капитала в организации путем развития индивидуальной компетенции работников при помощи их обучения, проведения тренингов, семинаров, курсов повышения квалификации.

В основе второй стратегии лежит формирование и использование структурного капитала. Он включает в себя знания, которые «принадлежат организации»: технология, изобретения, патенты, ноухау, процессы, системы, структура и внутренние правила, стратегия и культура компании. Одним из направлений данной стратегии является формирование структуры организации, направленной на интенсивный обмен знаниями внутри организации.

Третья стратегия основана на формировании и использовании знаний в рамках потребительского капитала. Потребительский капитал заключён в отношениях, которые устанавливает организация, то есть определяется отношениями с клиентами, потребителями, внешними партнёрами организации, индивидуальным подходом, сотрудничеством. Цель стратегии - построение эффективных внешних свя- 
зей, которые увеличивают конкурентоспособность организации; формирование имиджа компании; управление торговой маркой.

Четвертая стратегия основана на обмене знаниями между человеческим и потребительским капиталом. Данный обмен чаще всего происходит с помощью прямых контактов с потребителями, а также с помощью маркетинговых и социологических исследований.

Пятая стратегия основана на взаимодействии индивидуальных компетенций сотрудников и организационного капитала. Данная стратегия формирует корпоративную культуру созданием системы распространения индивидуального знания и его использования всеми сотрудниками организации.

Шестая стратегия основана на взаимодействии между элементами организационного и клиентского капитала. Целями стратегии является повышение качества обслуживания за счет применения новых технических средств, использование информационных технологий компании для привлечения клиентов. В рамках данной стратегии также формируется база данных о клиентах.

Седьмая стратегия - это стратегия, опирающаяся на одновременное взаимодействие между всеми элементами интеллектуального капитала.

Для любой организации, желающей обеспечить конкурентоспособность в сегодняшней глобальной информационной экономике, необходима интеллектуальная, исчерпывающая и простая в использовании система для управления запасами знаний, а также система доступа к знаниям и система приобретения новых знаний. Основной проблемой является выбор оптимальной организации управления знаниями на предприятии. При эффективном управлении знаниями инновационная способность организации возрастает.

В данном параграфе рассмотрены стратегии управления интеллектуальным капиталом по Гапоненко, которые позволяют сформи- 
ровать интеллектуальный капитал на предприятии и использовать для повышения конкурентоспособности организации. Данные стратегии направлены на создание новой стоимости, реализованной в продуктах, с помощью рационального формирования и использования знаний в организации. 


\section{ГЛАВА 2. МОНИТОРИНГ СОЗДАНИЯ И УПРАВЛЕНИЯ ИНТЕЛЛЕКТУАЛЬНОЙ ДОБАВЛЕННОЙ СТОИМОСТЬЮ НА ПРОМЫШЛЕННЫХ ПРЕДПРИЯТИЯХ В РФ}

\section{1. Состояние и проблемы создания интеллектуальной добавленной стоимости на промышленных предприятиях}

Традиционно в компаниях наиболее важными ресурсами считаются материальные активы, в особенности физические активы и капитал. Действительно, эти ресурсы играют важнейшую роль в создании стоимости компании. Тем не менее высокая конкурентоспособность фирмы невозможна в наше время без интеллектуального капитала, которому принадлежит главная роль в повышении конкурентоспособности и рыночной стоимости той или иной компании.

В современном мире практически все страны, прежде всего развитые, делают ставку на инновационный путь экономического роста. Носителем всего инновационного является человек, поэтому любая организация должна заботиться о развитии интеллектуального капитала и о том, чтобы добавленная стоимость интеллектуального капитала постоянно увеличивалась. Информационной базой анализа состояния управления интеллектуальной добавленной стоимостью на промышленных предприятиях послужили статистические сборники по инновационной деятельности [37] и информационному обществу НИУ ВШЭ, включающие данные за период с 2000 по 2016 годы.

Эффективность управления добавленной стоимостью интеллектуального капитала прямо влияет на результаты инновационной деятельности промышленных предприятий. Наличие у предприятия интеллектуальных ресурсов определяет его способности к устойчивому и конкурентоспособному развитию. 


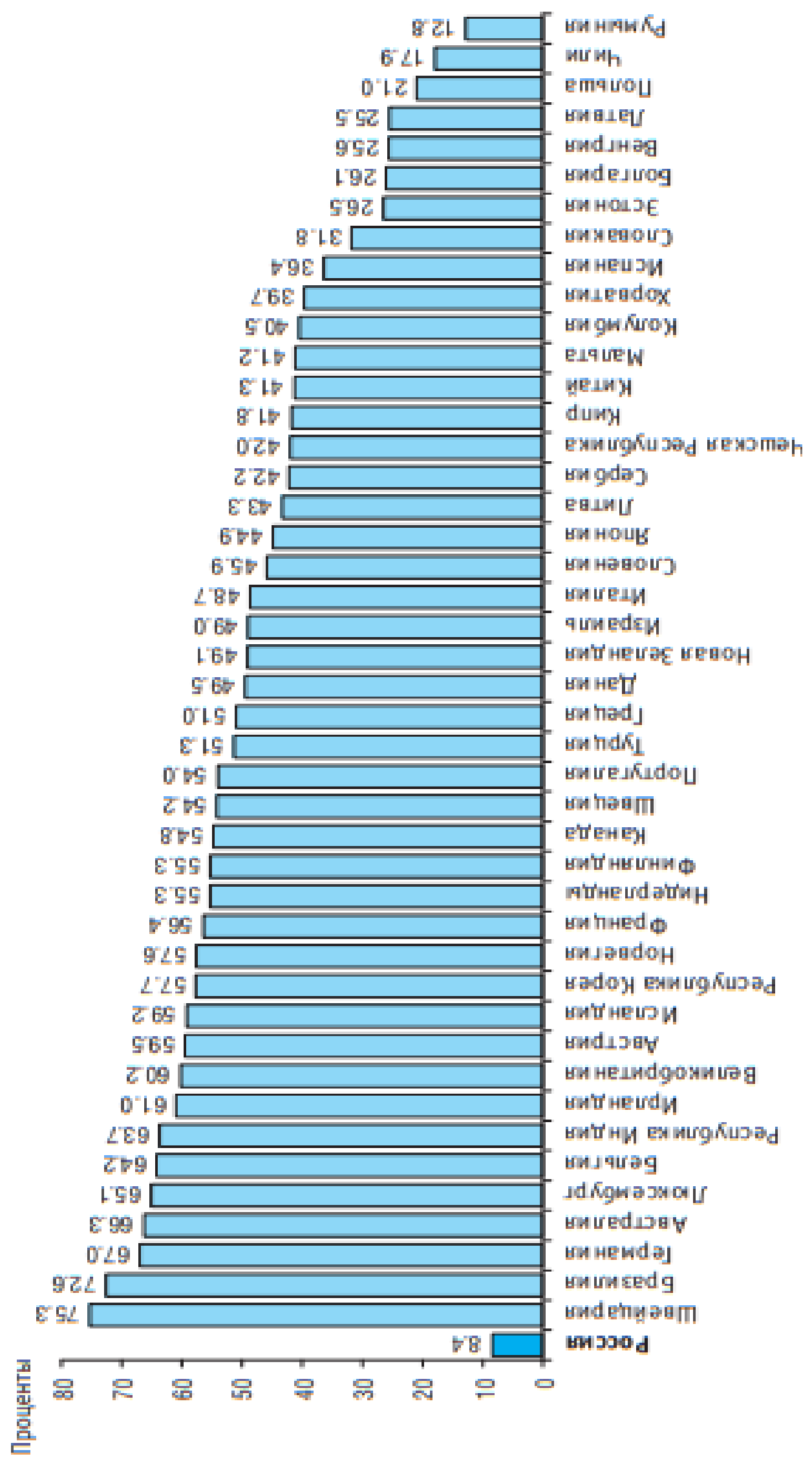

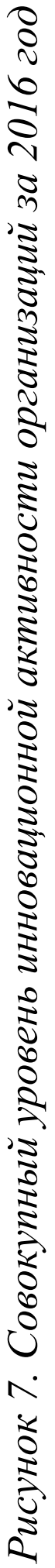


Как видно на рисунке 7, уровень инновационной активности России составляет $8,4 \%$, что по сравнению другими странами очень низкий показатель, который нужно поднимать, чтобы быть более конкурентоспособной страной. Лидером в данном направлении является Швейцария. Швейцария заняла лидирующие позиции благодаря человеческому капиталу. Интеллектуальный потенциал общества является двигателем прогресса. Именно интеллект человека является первой ступенью для формирования инноваций. И по тому, насколько качественно данный интеллект в масштабах нации будет представлен в социуме, можно уже судить о потенциале к инновационной активности. Также можно сказать, что интеллектуальная способность общества зависит от уровня образования. Естественно, необходимо сделать существенные поправки в сторону качества образования, доступности образования и т.д. Можно вывести следующую зависимость: чем выше культура образования, тем больше вероятность инновационной деятельности для данного общества. Швейцария входит в десятку наиболее образованных стран в соответствии с индексом образования по странам, разработанным Организацией Объединенных Наций.

На российских промышленных предприятиях основными направлениями деятельности по созданию новых знаний являются: сфера исследований и разработок (работа подразделений НИОКР), систематизация имеющейся патентной информации по внутренним и приобретенным разработкам, сведения о приобретенном программном обеспечении и об обучении персонала в целях воспроизводства человеческого капитала.

За последние годы удельный вес российских промышленных предприятий, осуществляющих технологические инновации в общем числе организаций, колеблется в пределах 10\%, а организаций, внедряющих маркетинговые инновации, составляет 2,5 и 1,9\% соответственно, идет снижение маркетинговых инноваций с 2010 года по 
2016 на 0,6 пунктов.

Аналогичная ситуация характерна при внедрении промышленными предприятиями организационных инноваций. Так, в 2016 году доля компаний, на которых реализованы организационные инновации, составляет 2,8\% от общего числа организации. По данным Евростата, по осуществлению маркетинговых и организационных инноваций Россия находится на последнем месте в общем числе организаций, такие страны, как Малайзия, Австралия, Чили, Филиппины, имеют удельный вес организаций, осуществляющих технологические инновации, более $50 \%$.

Удельный вес затрат на технологические инновации в общем объеме отгруженных товаров, выполненных работ, услуг с 2000 до 2016 года находится практически на одном уровне, при этом плавно, год от года, затраты на технологические инновации растут. Удельный вес инновационных товаров, работ и услуг в общем объеме отгруженных товаров, выполненных работ и услуг растет с 2000 до 2013 года в 2 раза.

Увеличение удельного веса инновационных товаров можно объяснить тем, что в промышленном производстве в Российской Федерации происходят изменения в структуре затрат на технологические инновации. Доля затрат собственных средств организаций сокращается с 2010 по 2016 год при увеличении доли средств федерального бюджета почти в 4 раза (рисунок 9).

Основными видами расходов в промышленном производстве остаются расходы на приобретение машин и оборудование и на проведение исследований и разработок, что составляет 53,2\% и 23,6\% соответственно. 


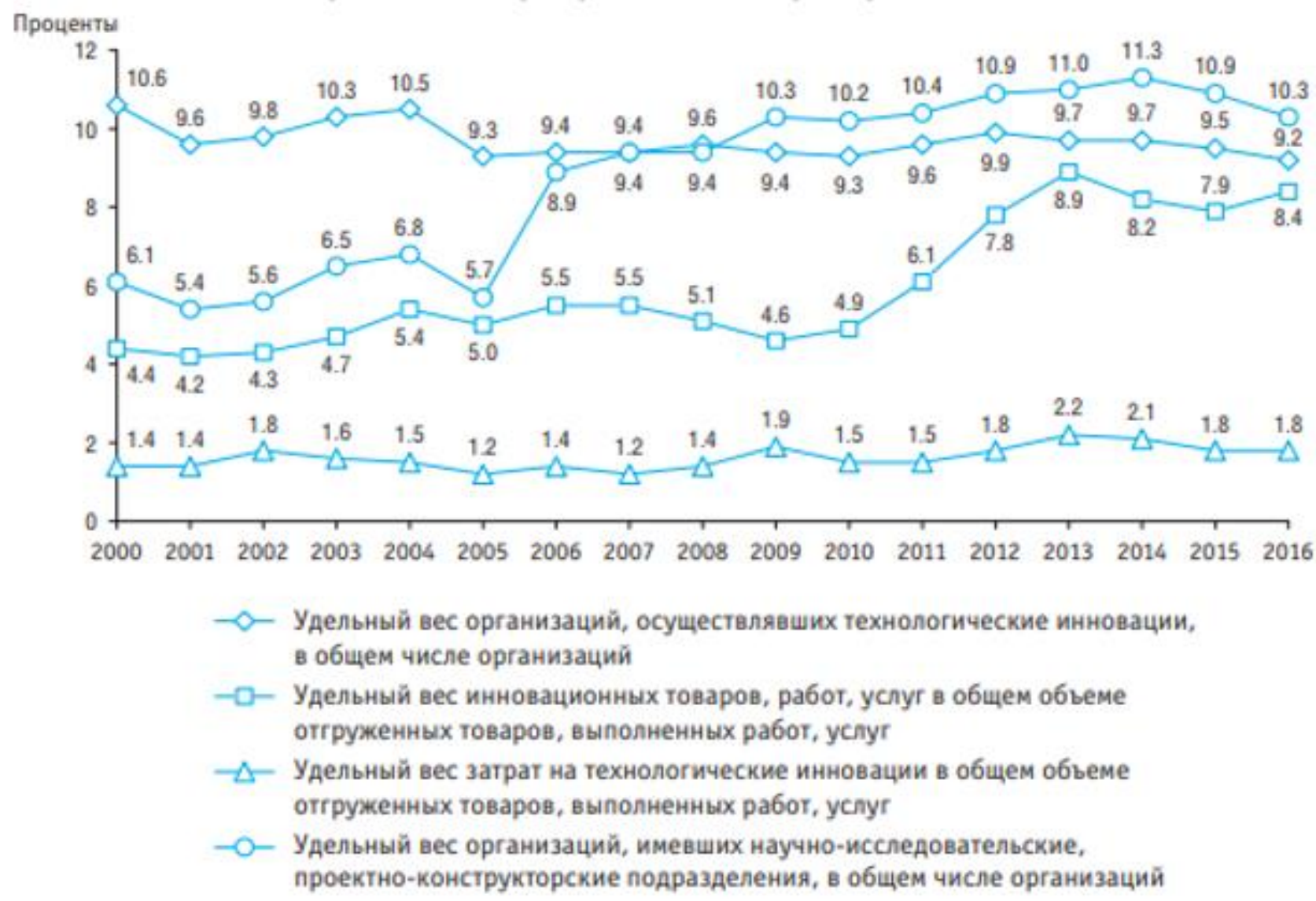

Рисунок 8. Динамика основных показателей инноващионной
деятельности для промышленных предприятий России

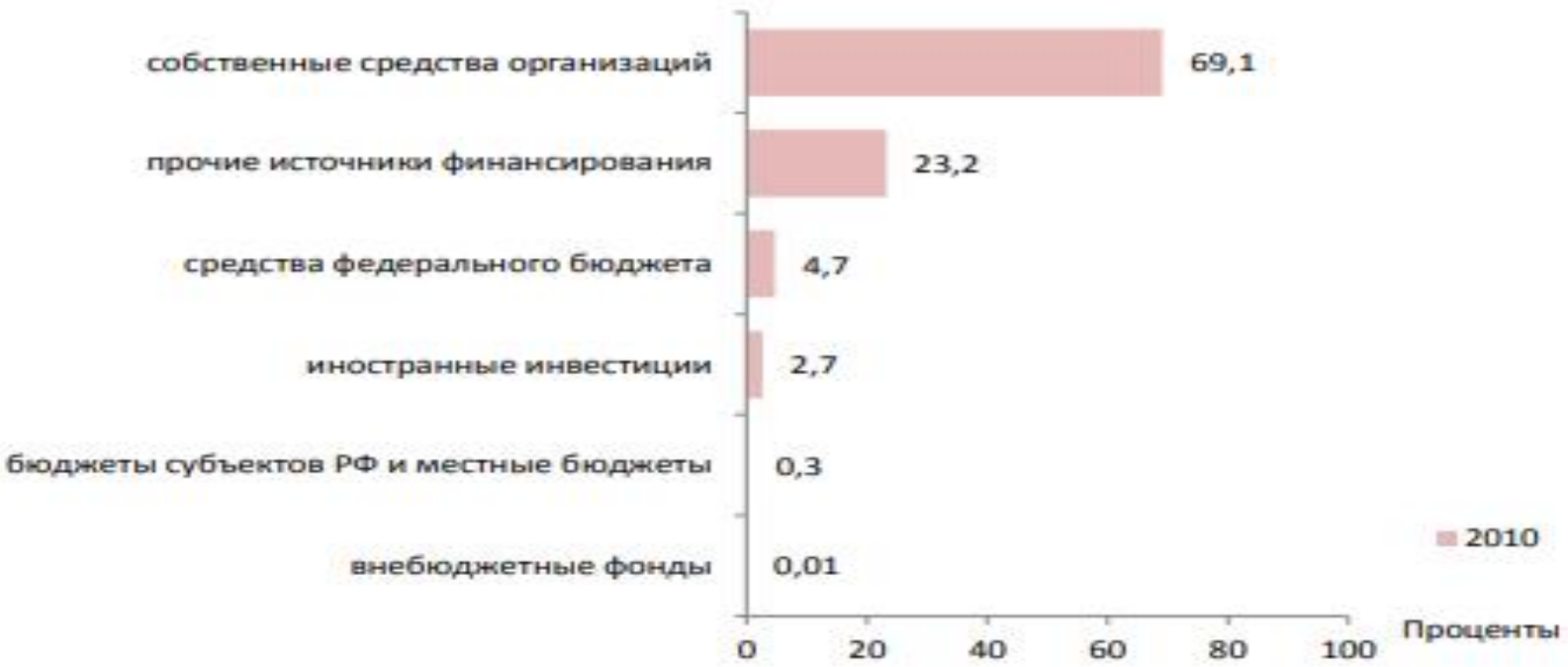

Рисунок 9. Структура затрат на технологические инновации крупных и средних организачий по источникам финансирования за 2010 год 


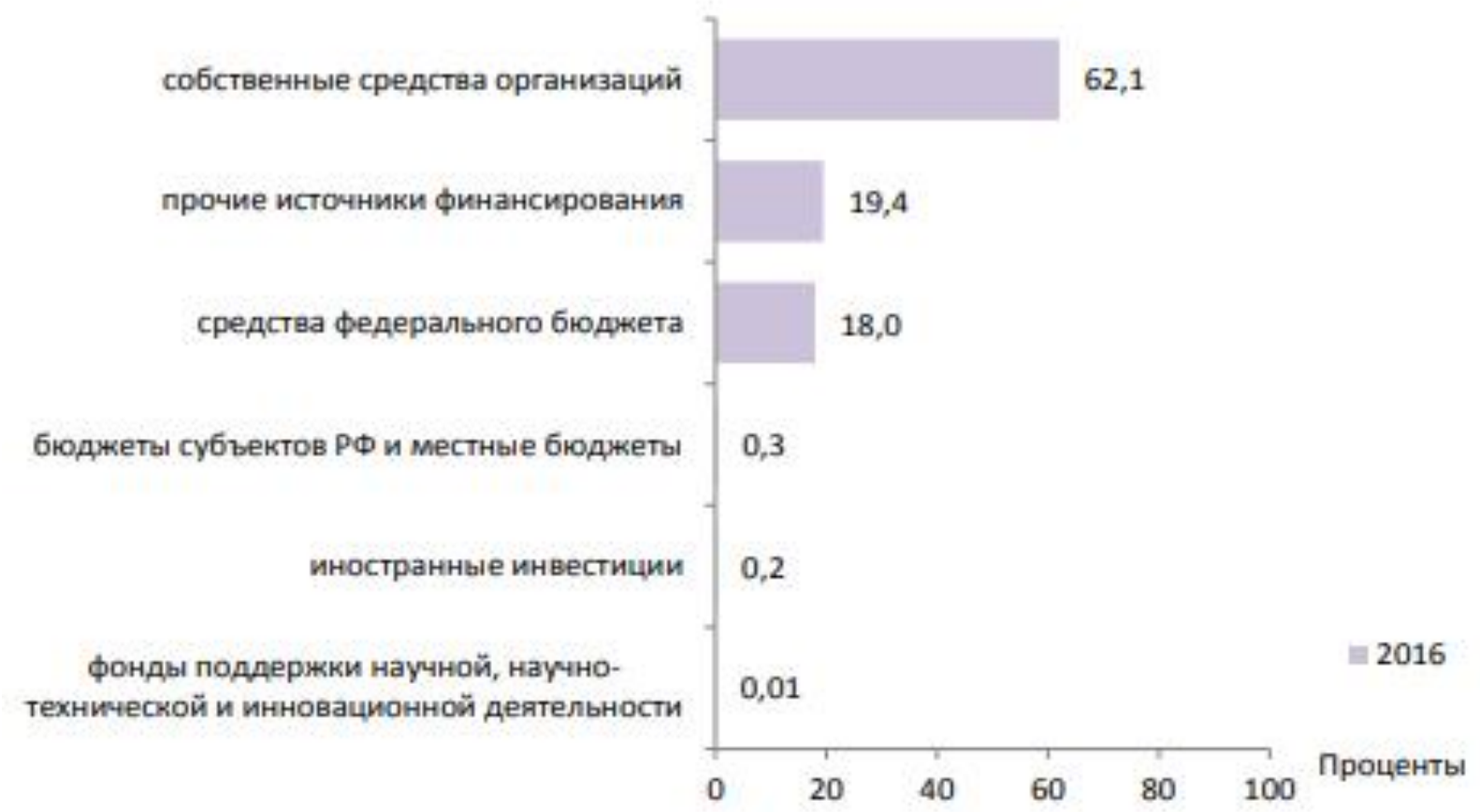

Рисунок 10. Структура затрат на технологические инновации крупных и средних организаций по источникам финансирования за 2016 год

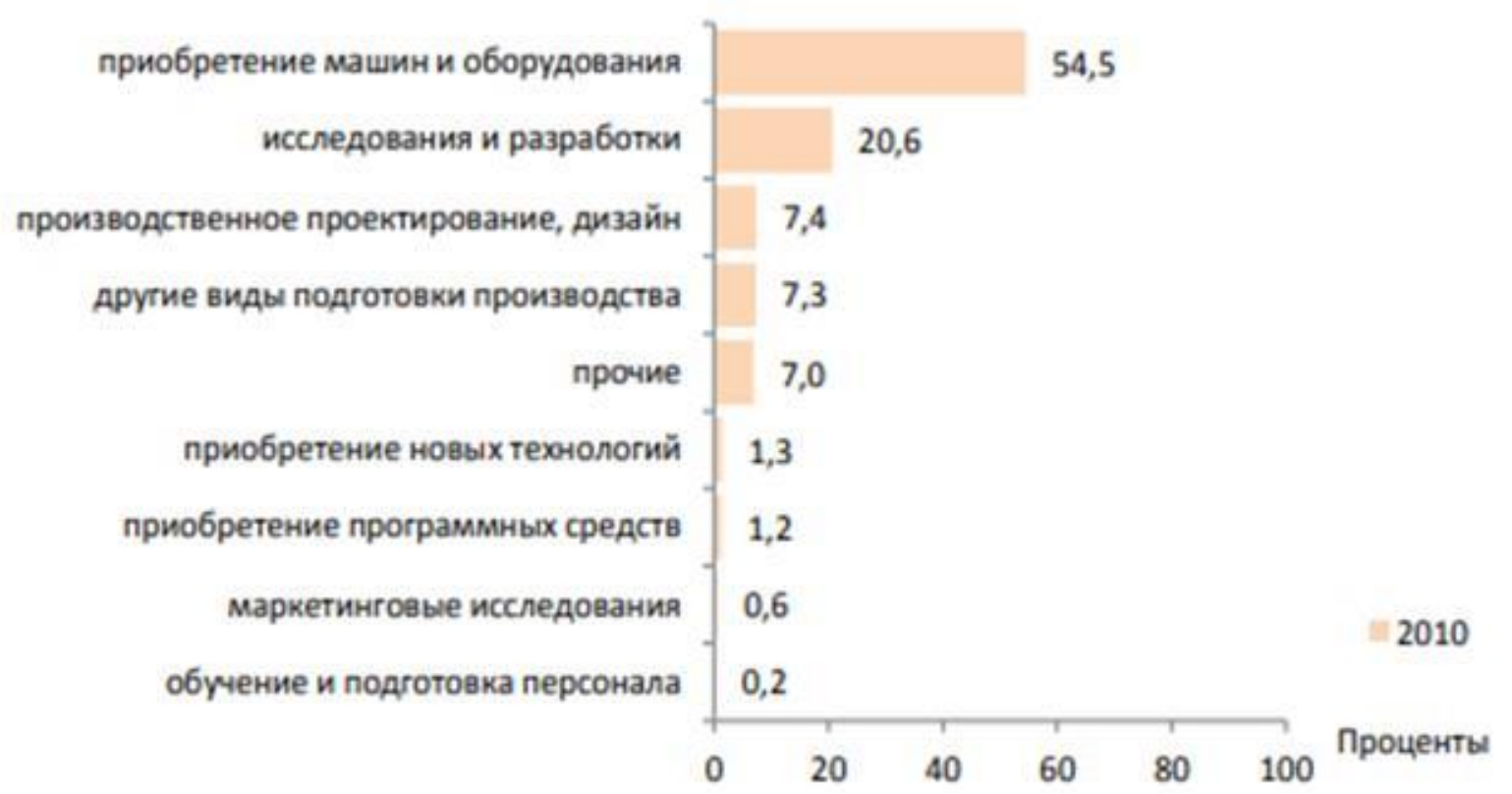

Рисунок 11. Структура затрат на технологические инновации крупных и средних организаций промышленного производства по видам деятельности за 2010 год 


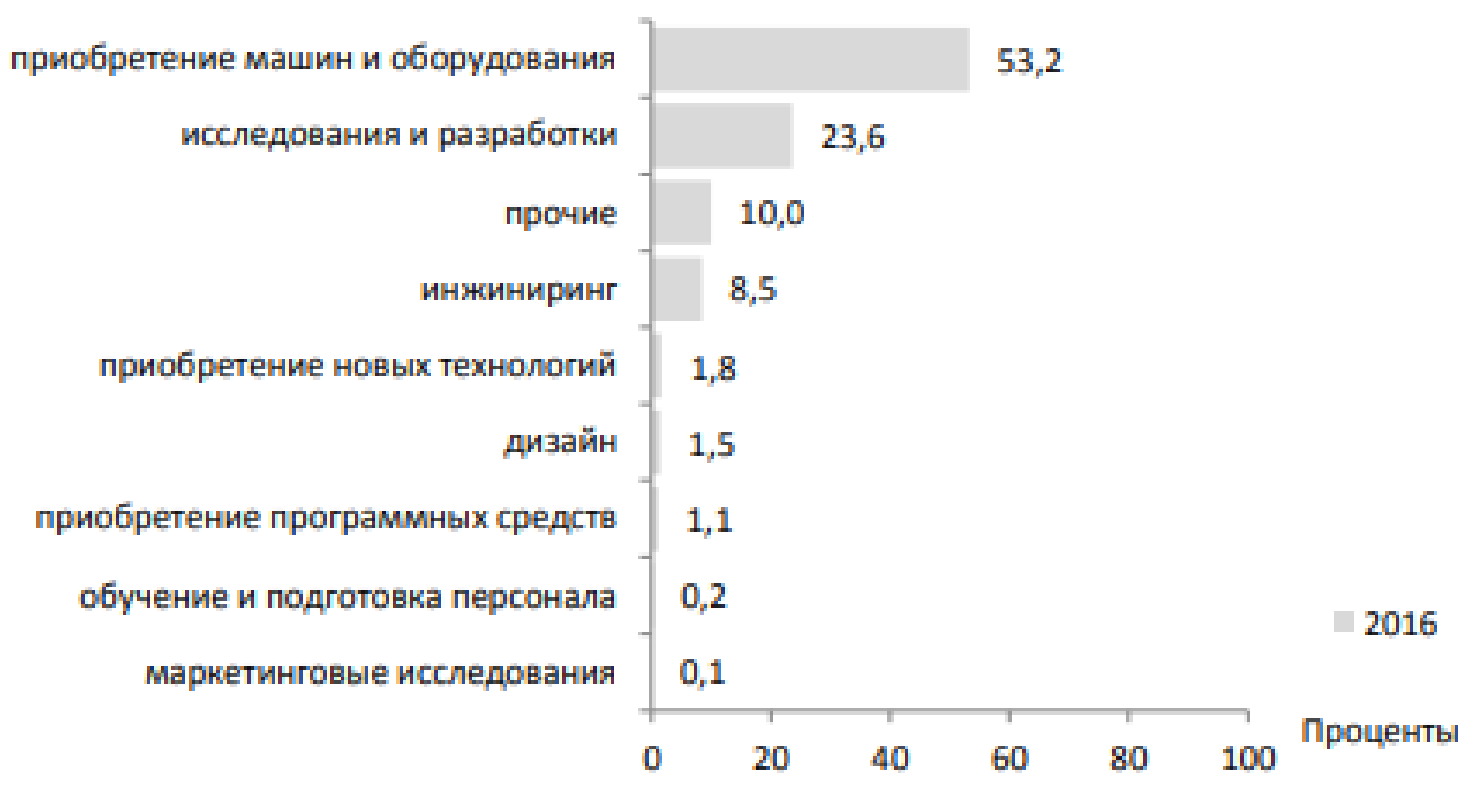

Рисунок 12. Структура затрат на технологические инновации крупных и средних организаций промышленного производства по видам деятельности, 2016 год

Структура затрат на технологические инновации по видам инновационной деятельности в промышленном производстве на протяжении рассматриваемого периода практически не меняется, более половины расходов - это расходы на приобретение машин и оборудования.

Результатом инновационной деятельности является объем произведенной инновационной продукции, выполненных работ, оказанных услуг. В 2016 году объем инновационных товаров (работ, услуг) составил 4364,3 млрд рублей, из него на организации, осуществляющие технологические инновации, приходилось 3967,8 млрд рублей, т.е. почти $91 \%$.

Формирование интеллектуального капитала предприятий происходит за счет внешнего обмена информацией, технологиями и разработками, с помощью которого происходит накопление опыта взаимодействия с внешней средой. У инновационно-активных компаний появляются специфические информационные потоки, обогащающие процессы исследовательской деятельности и возможности 
кооперации по данному направлению с другими экономическими субъектами. Основу внешнего взаимодействия составляют процессы технологического обмена, обмена производственной, организационной, маркетинговой и другими видами коммерческой информации.

В рамках реализации совместных проектов происходит кооперация экономических субъектов, направленная на создание инноваций и новых решений. Доля промышленных предприятий, принимавших участие в подобных проектах, находится на уровне 4\% от общего числа компаний и более $30 \%$ для предприятий, осуществляющих технологические инновации. В сравнении со странами Евросоюза по показателю «доля предприятий, участвовавших в совместных проектах по выполнению исследований и разработок, в общем числе организаций, осуществляющих технологические инновации» российские предприятия находятся на среднем уровне, тем не менее отставание от передовых экономик почти двукратное. На данный момент наблюдается снижение данного показателя - в 2014 году был $36 \%$ и за 2 года опустился до $31,6 \%$.

На основе анализа годовых финансовых отчетов ряда компаний промышленной отрасли: ОА «Электросвязь», «Русская медная компания», ПАО «Норильский Никель», «Codelco» (Чили), «Phelps Dodge» (США), «ВНР Billiton Group» (Австралия), проведены исследование интеллектуальной добавленной стоимости и сравнение уровня интеллектуального капитала российских и зарубежных компаний медной отрасли. Российский рынок медного производства делится в основном между тремя участниками рынка, именно эти предприятия были выбраны для измерения стоимости добавленной интеллектуальным капиталом. 


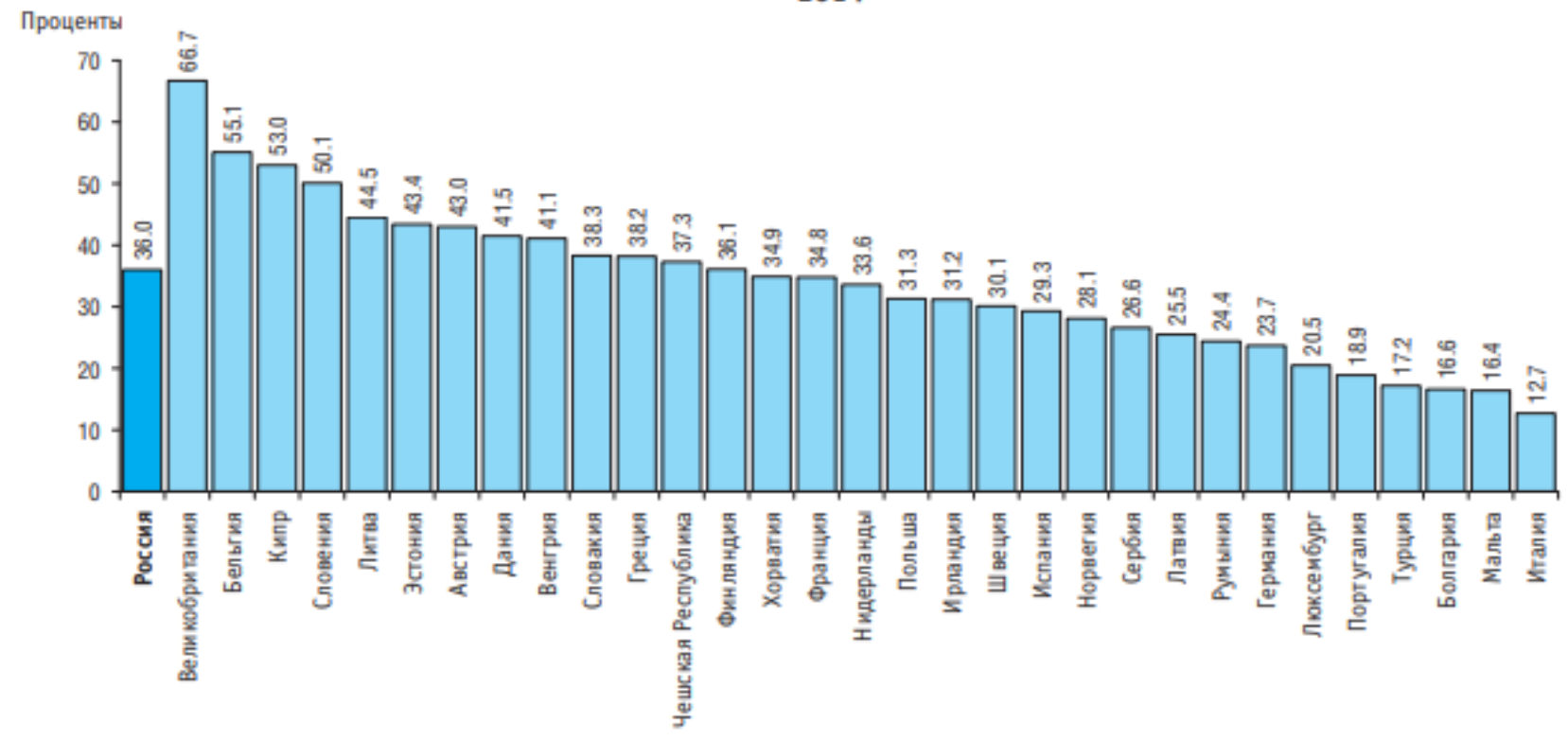

Рисунок 13. Доля промышленных предприятий, участвовавших в совместных проектах по выполнению исследований и разработок, в общем числе организаций, осуществляющих технологические инновации за 2014 год

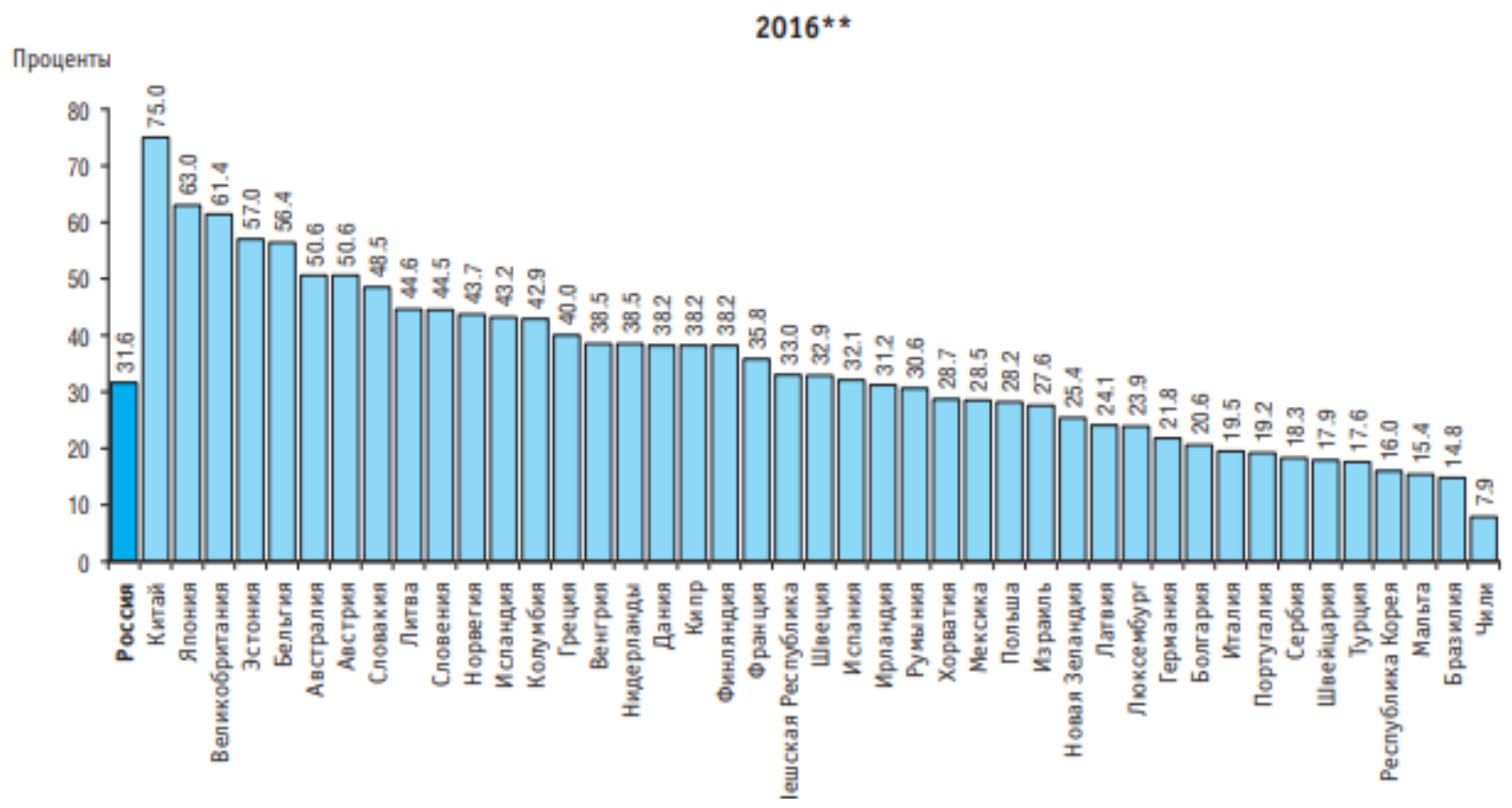

Рисунок 14. Доля промышленных предприятий, участвовавших в совместных проектах по выполнению исследований и разработок, в общем числе организаџий, осущуествляющчих инноваџии за 2016 год 


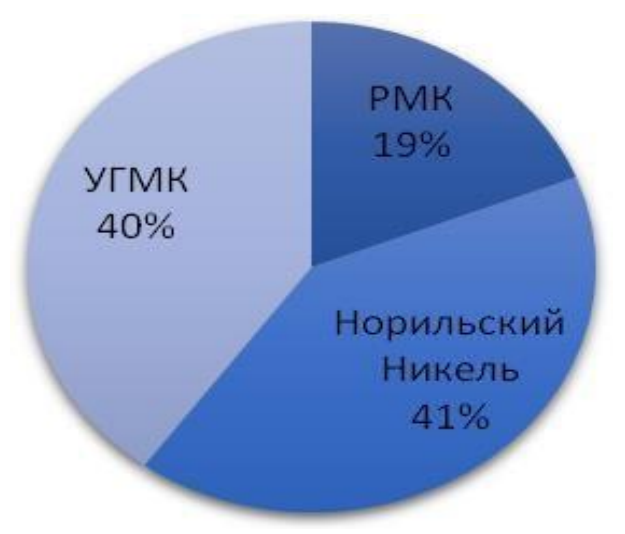

Рисунок 15. Структура производства меди в России в 2017 году

Для измерения интеллектуальной добавленной стоимости проведем анализ с использованием модели «коэффициента добавленной стоимости интеллектуального капитала» (VAIC) за период 2013-2017 года. Основной целью оценки интеллектуального капитала является обеспечение устойчивого развития компании. Располагая информацией о величине данного показателя, можно сформировать долгосрочную стратегию фирмы в постоянно меняющейся среде. Особое значение интеллектуальный капитал представляет для компании, осуществляющей свою деятельность в какой-то высокотехнологичной отрасли. Если она работает на рынке давно, завоевала хорошую репутацию и имеет в штате высококвалифицированных специалистов, то и интеллектуальный капитал будет иметь высокие значения. Все расчёты, представленные в работе, основываются на годовой бухгалтерской (финансовой) отчетности российских и зарубежных предприятий. Ценность бизнеса во многом определяется его интеллектуальными и информационными ресурсами, и на сегодняшний день большая часть активов компаний имеет нематериальный характер. Результаты исследования ИК компаний в виде графиков представлены на рисунке 16, 17. 


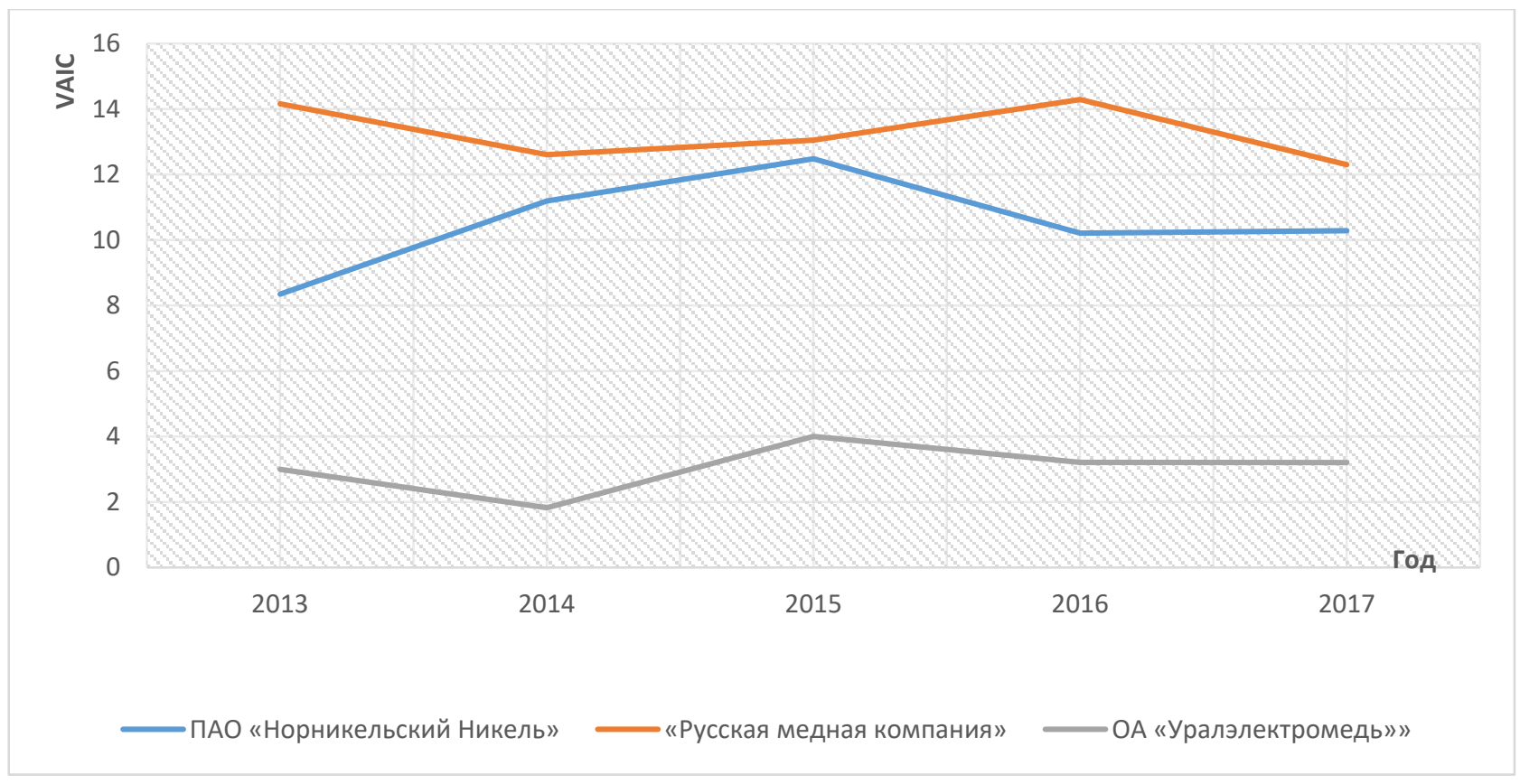

Рисунок 16. VAIC в российских компаниях ${ }^{2}$

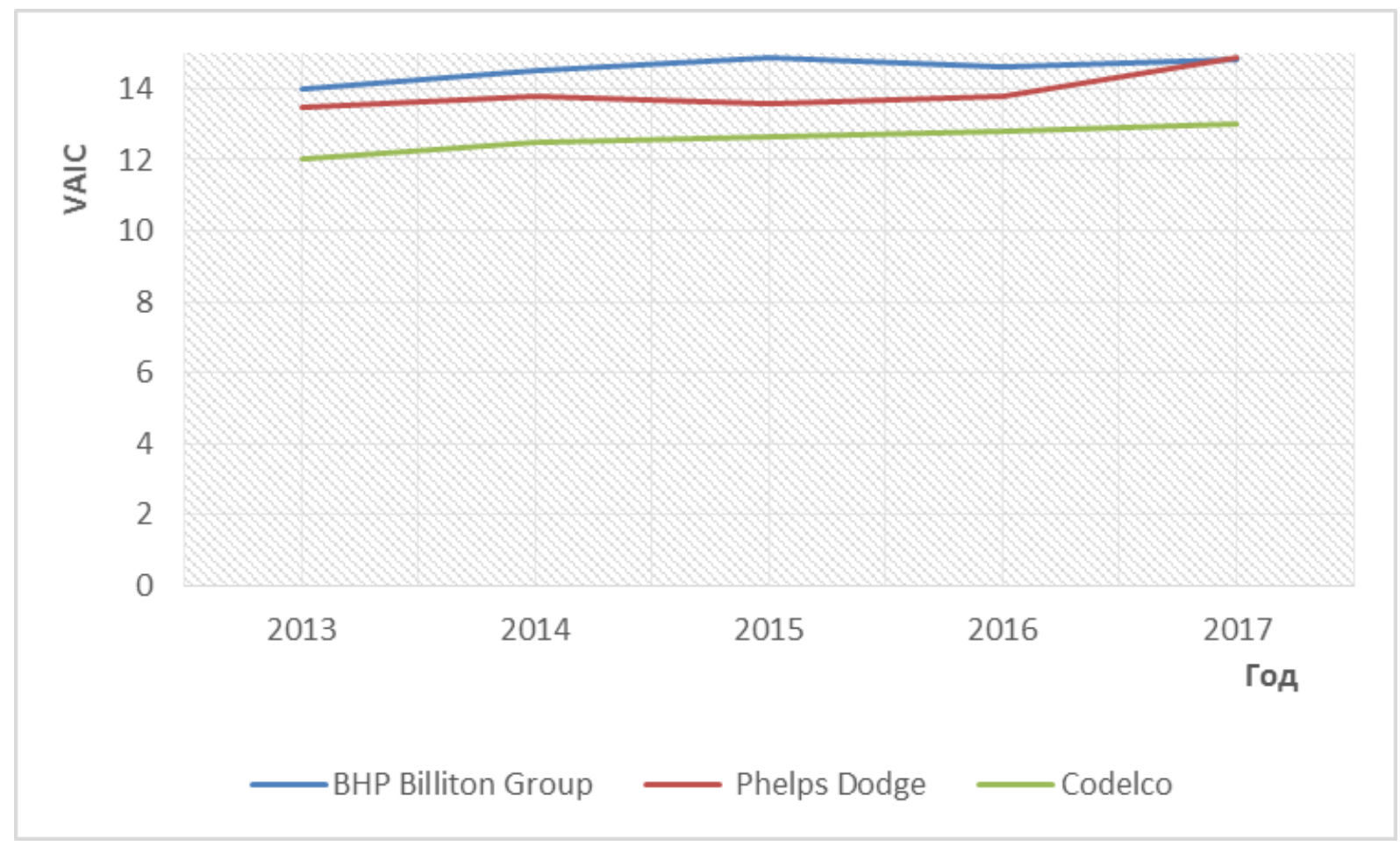

Рисунок 17. VAIC в зарубежных компаниях ${ }^{3}$

${ }^{2}$ Составлено авторами по [41-43].

${ }^{3}$ Составлено авторами по [44-46]. 
По результатам исследования можно сделать следующие выводы:

1) интеллектуальная добавленная стоимость зарубежных предприятий в исследованном временном интервале в среднем выше, чем российских. Отличие в основном именно в человеческом капитале;

2) значения коэффициента VAIC у зарубежных компаний характеризуются большей стабильностью, в отличие от российских компаний;

3) менеджерам российских компаний для успешной конкуренции на мировых рынках следует уделять большее внимание развитию и управлению интеллектуальной добавленной стоимостью;

4) как было выявлено выше, главным направлением развития интеллектуального капитала, а как следствие, и интеллектуальной добавленной стоимости, для исследованных российских компаний является повышение человеческого капитала.

Внутренние препятствия для развития инновационной деятельности в крупных компаниях России прослеживаются в двух направлениях: во-первых, это отсутствие мотивации у руководства к долгосрочному росту компании; во-вторых, проблема, вытекающая из первого пункта - компании не умеют и не готовы к внедрению инноваций.

Главной внутренней проблемой является отсутствие ответственности менеджмента за развитие компании на среднесрочном горизонте. Это связано с непредсказуемостью экономической ситуации, и из этого следует, что менеджмент ставит краткосрочные планы развития компании - все реально исполняемые планы являются краткосрочными, что для внедрения инновации неприемлемо. Также можно отметить, что инновационные планы носят долгосрочный характер, следовательно, текущее руководство не несет прямой ответственности за конечный результат. Среднесрочных планов инновационного развития либо не существует, либо отсутствует реальная 
ответственность за их неисполнение. Таким образом, чтобы решить проблему с внедрением инноваций, нужно решать операционные задачи и максимизировать прибыль в краткосрочном периоде. Данный подход нельзя применять для инновационных проектов со сроком реализации 5 и более лет, так как данный срок выходит за пределы краткосрочного горизонта планирования. Отсутствие у менеджмента мотивации к инновациям и короткий горизонт планирования приводят к отсутствию в компаниях опыта системного и последовательного внедрения инноваций. Долговременная низкая инновационность приводит к двум наблюдаемым проблемам внутри компаний.

Первая - отсутствие кадров, обладающих необходимыми компетенциями для успешного внедрения инноваций, в том числе управлением изменениями, рисками, масштабированием результатов, а также организацией культуры непрерывного улучшения.

Вторая - внутренние процессы в крупных компаниях сфокусированы на краткосрочных, операционных задачах и не настроены на внедрение инноваций. Это касается как минимум двух процессов: управления инновациями и закупок. В компаниях зачастую отсутствует система управления инновациями, например, в рамках проектного управления отсутствуют четкие и прозрачные критерии выбора инновационных проектов. Это, например, приводит к формированию в компании культуры боязни неудачного внедрения инноваций и последующих санкций со стороны руководства: безопаснее не предпринимать ничего, так как за отсутствие действий санкции не применяются. Это приводит к тому, что компании не заинтересованы во внедрении даже собственных разработок. Схожие проблемы существуют и в системе закупок, которая сфокусирована на цене предложения, а не качестве предлагаемой продукции, что отсекает потенциально интересные инновационные идеи. Также процессы не приспособлены к закупкам нетиповой продукции, которую невозможно напрямую сравнить с аналогами по цене. Это приводит к су- 
щественному усложнению закупки услуг по разработке прототипов либо компонентов для их производства, необходимых для проведения опытно-конструкторских работ, и, как следствие, тормозит развитие инноваций в компании.

Обзор инновационной политики за последние годы, в том числе в 2015-2016 гг., показывает, что государство, проявляя активность, все же было и остается в основном сосредоточенным на: поддержке науки и образования; обеспечении условий для предпринимателей и венчурных инвесторов; целевой финансовой и нефинансовой поддержке стартапов. Лишь в последние годы государство начало проявлять заметную активность по стимулированию инноваций в крупных компаниях, эффект от которой еще в любом случае не проявился в показателях панели управления.

Наличие у предприятия интеллектуальных ресурсов определяет его способности к устойчивому и конкурентоспособному развитию. Совокупность знаний, умений и навыков, в том числе сформированных в нематериальные и прочие активы, рассматриваются как интеллектуальный капитал предприятия.

Эмпирически наличие интеллектуального капитала у предприятия можно идентифицировать через его успешность на рынке и способность формировать высокую добавленную стоимость в продукте. Однако с научно-методической точки зрения подходы к оценке интеллектуального капитала в настоящее время не являются унифицированными и не позволяют получить объективную стоимостную оценку этого капитала.

Эмпирические исследования по данной теме отличаются друг от друга по используемым данным, временным периодам. Однако можно отметить общие гипотезы, которые подтвердились в большинстве работ по результатам эмпирических исследований:

- Существует положительная связь между уровнем интеллек- 
туального капитала и результатами деятельности компании;

- существует взаимное влияние отдельных компонентов интеллектуального капитала;

- существует незначимость отдельных элементов, в особенности человеческого капитала, без наличия остальных.

Итак, в сложившейся ситуации с инновациями в России важная роль в стимулировании развития принадлежит государству. Однако имеется ряд важных проблем в текущей государственной политике. Одной их них является отсутствие стратегического подхода к отраслевым стандартам, выражающееся в отсутствии у государства четкого плана действий относительно существующих различий в российских и международных стандартах: продвижению российских стандартов, взаимному сближению стандартов для упрощения экспорта либо их дифференциации для защиты внутреннего рынка. Применительно к инновациям это приводит к двум проблемам. Во-первых, различие российских и международных стандартов является существенным барьером для развития экспорта. Во-вторых, ряд отраслевых стандартов не пересматривался уже в течение длительного времени и не отвечает современным требованиям. Следует отметить, что за последние несколько лет государством было создано большое количество инструментов, направленных на развитие инноваций, в том числе на увеличение экспорта высокотехнологичной продукции.

\section{2. Особенности управления интеллектуальной добавленной стоимостью на промышленных предприятиях}

Основной целью управления интеллектуальным капиталом и инновациями промышленных предприятий является обеспечение максимально возможной высокой эффективности интеллектуального корпоративного капитала, а также сохранении его качества, актуальности и работоспособности [36]. Исследование комплексной систе- 
мы управления интеллектуальным капиталом и инновациями промышленных предприятий представляется весьма актуальным, поскольку позволяет расширить сложившийся в условиях отечественной экономики в течение последних десятилетий подход.

Стратегическое управление интеллектуальным капиталом для создания интеллектуальной добавленной стоимости предприятия является одним из наиболее перспективных методов в формировании целей и задач, способствующих развитию организации.

В процессе управления интеллектуальной добавленной стоимостью организации руководство предприятия решает следующие задачи:

- создание и оценка интеллектуальной добавленной стоимости на предприятии;

- разработка мероприятий и механизмов для эффективного управления ИДС.

Объектом управления является интеллектуальная добавленная стоимость.

Субъектом - сотрудники организации, принимающие решения по управлению ИДС.

Рассмотрим основные задачи управления ИДС компании и управленческие решения этих самых задач.

Таблица 7. Основные управленческие задачи управлением ИДС

\begin{tabular}{|l|l|l|}
\hline \multicolumn{1}{|c|}{ Задачи управления } & \multicolumn{1}{|c|}{$\begin{array}{c}\text { Решения в области } \\
\text { ИДС }\end{array}$} & \multicolumn{1}{c|}{$\begin{array}{c}\text { Методы } \\
\text { управления ИДС }\end{array}$} \\
\hline $\begin{array}{l}\text { Планирование, орга- } \\
\text { низация, контроль и } \\
\text { регулирование про- } \\
\text { цессов создания ИДС }\end{array}$ & $\begin{array}{l}\text { - разработка стратегий со- } \\
\text { здания ИДС на предприятии, }\end{array}$ & $\begin{array}{l}\text { Применение для } \\
\text { оценки методики } \\
\text { оденки компонентов ИДС }\end{array}$ \\
\hline
\end{tabular}

${ }^{4}$ Составлено авторами по [47]. 
Продолжение Таблицы 7

\begin{tabular}{|c|c|c|}
\hline $\begin{array}{l}\text { Образование иннова- } \\
\text { ционно-восприимчи- } \\
\text { вой среды, создающей } \\
\text { условия для развития } \\
\text { потенциала сотрудни- } \\
\text { ков для увеличения } \\
\text { ИДС предприятия }\end{array}$ & $\begin{array}{l}\text { - использование фондов } \\
\text { знаний и их формализация, } \\
\text { - увеличение производи- } \\
\text { тельности интеллектуально- } \\
\text { го труда }\end{array}$ & $\begin{array}{l}\text { - оценка вклада со- } \\
\text { трудника в интел- } \\
\text { лектуальный про- } \\
\text { цесс, } \\
\text { - мотивация интел- } \\
\text { лектуального труда }\end{array}$ \\
\hline $\begin{array}{l}\text { Формирование и раз- } \\
\text { витие организацион- } \\
\text { но-методической ос- } \\
\text { новы управления ИДС }\end{array}$ & $\begin{array}{l}\text { - регламентация и формали- } \\
\text { зация различных процессов } \\
\text { и процедур управления ИДС, } \\
\text { представления их в виде } \\
\text { оформленных документов, } \\
\text { - установление прав и ответ- } \\
\text { ственности сотрудников, за- } \\
\text { действованных в создании и } \\
\text { использовании интеллекту- } \\
\text { ально- информационной ба- } \\
\text { зы предприятия }\end{array}$ & $\begin{array}{l}\text { - разработка ин- } \\
\text { струкции по управ- } \\
\text { лению ИДС, } \\
\text { - составление } \\
\text { должностных ин- } \\
\text { струкций, } \\
\text { - разработка мето- } \\
\text { дик по управлению } \\
\text { ИДС }\end{array}$ \\
\hline
\end{tabular}

Управленческое решение - это результат индивидуальной или коллективной интеллектуальной деятельности субъекта управления в условиях организационных возможностей фирмы, направленный на совершенствование совместной деятельности [48].

Выделим особенности решений управления при создании интеллектуальной добавленной стоимости на промышленном предприятии. Система принятия управленческих решений является одним из элементов интеллектуального капитала. Принимаемые решения по управлению интеллектуальной добавленной стоимостью на предприятии в любом случае должны иметь правовую основу.

В процессе построения экономики, которая базируется на интеллектуальных составляющих, меняется технология принятия управленческих решений. В экономике нового типа решения должны приниматься нестандартные и оригинальные, так как они должны решать нестандартные проблемы в управлении интеллектуального 
капитала организации, это должно прослеживаться не только у руководителей высшего звена, но у руководителей среднего и низшего звеньев.

Решения, которые принимаются в настоящее время, должны разрабатываться и приниматься коллегиально, так как предприятия укрупняются и один человек не должен брать на себя всю долю ответственности. Процессы контроля над исполнением решений также должны происходить коллегиально. В данном случае происходит разделение ответственности среди всех членов коллектива.

Методология принятия решений также поддается изменениям. Решения разрабатываются с помощью методов, основанных на неаргументированных доказательствах, так как применение количественных методов затруднено при принятии решений управления интеллектуальной добавленной стоимостью на предприятии. Так, методы, которые основаны на знаниях интуиции, являются достаточно актуальными для управления интеллектуальным капиталом и стоимостью, созданной им. Нужно помнить также, что решения по управлению интеллектуальными активами всегда несут в себе риски и неопределенность, здесь очень сложно просчитать, насколько то или иное решение подойдет.

Указанные методы принятия решений в управлении создании интеллектуальной добавленной стоимости не дают нам полного представления всего разнообразия методов, так как на данном этапе только идет активное развитие данной деятельности. Управление интеллектуальной добавленной стоимостью на промышленном предприятии сводится к управлению составляющими интеллектуального капитала, так как чем больше интеллектуальный капитал, тем больше стоимость, созданная интеллектуальным капиталом на предприятии.

Рассмотрим факторы, которые влияют на управление стоимостью, добавленной интеллектуальным капиталом и, как следствие, 
на принятие решений управления им. Среди факторов, прямо влияющих на стоимость объектов интеллектуальной собственности, следует выделить следующие [49]:

1) затраты на разработку и регистрацию объектов интеллектуальной собственности;

2) затраты на организацию использования объектов интеллектуальной собственности, включая затраты на маркетинг;

3) затраты на страхование рисков;

4) время разработки и освоения нового изделия;

5) жизненный цикл товара на рынке;

6) срок полезного использования объекта интеллектуальной собственности;

7) инфляционный фактор;

8) фактор морального старения объекта интеллектуальной собственности.

В наше время система управления интеллектуальными активами является одной из важнейших подсистем управления предприятием в условиях быстро изменяющейся среды, ограниченных ресурсов и научно-технологического прогресса. Интеллектуальные активы предприятия во многом обусловливают возникновение уникальных конкурентных преимуществ предприятия и определяют его рыночную стоимость.

Решения, принимаемые при создании интеллектуальной добавленной стоимости должны рассматриваться через систему управления интеллектуальными активами промышленного предприятия.

Данная система управления делится на несколько подсистем. Рассмотрим какие функции осуществляют данные подсистемы, это позволит нам понять, в рамках какой подсистемы руководители 
принимают решения управления при создании интеллектуальной добавленной стоимости.

Первая рассмотренная нами подсистема - подсистема управления НИОКР и технологическими инновациями - осуществляет функции планирования, организации, контроля и регулирования процессов развития научных и технических знаний сотрудников; формируется информационно-интеллектуальная среда, которая способствует развитию новых знаний, генерированию новых идей. Также формируется интеллектуальная база предприятия, что позволяет предприятию быстрее приспосабливаться к изменчивой внешней среде, появляется также возможность с помощью информационноинтеллектуальных ресурсов производить ту или иную продукцию, пользующуюся наибольшим спросом среди населения.

Следующая подсистема управления интеллектуальными ресурсами - подсистема управления инновационным потенциалом и развитием сотрудников. В рамках данной подсистемы решаются вопросы:

- по формированию и эффективному использованию фондов знаний;

- по прогнозированию потребности в интеллектуальных ресурсах;

- по выявлению интеллектуального потенциала сотрудников;

- по увеличению производительности интеллектуального труда сотрудников;

- по развитию мероприятий для сплочения коллектива, поощрению инициативных сотрудников, развитию лидерских качеств в коллективе.

Для решений вопросов по управлению организационнометодической базой управления интеллектуальными активами существует подсистема управления организационно-методической базой управления интеллектуальными активами. 
Данная подсистема координирует всех сотрудников на предприятии, которые задействованы в процессе управления интеллектуальными активами, на основе регламентации различных процедур, описанных и представленных в виде оформленных согласно определенным формализованным документам. Она также обеспечивает согласованность разной деятельности специалистов для создания единой информационно-интеллектуальной базы организации.

Подсистема управления информацией и коммуникациями решает проблемы по формированию системы методов и способов сбоpa, передачи, накопления, обработки, хранения, представления и использования внутренней и внешней информации, разработке и использованию технологии получения, обработки, анализа, интерпретации первичной информации, проектированию информационных потоков, формированию и поддерживанию информационной базы предприятия, разработке методов и способов ее рационального использования, определению размера и структурированию всей необходимой для обеспечения эффективной деятельности информации.

В данной подсистеме решается вопрос по программному обеспечению организации, идет процесс накопления и развития знаний о технологиях программирования, выбора для внутрифирменного использования приемлемого программного обеспечения и соответствующей технической базы, обеспечения бесперебойной работы пользователей с информационной базой данных.

В рамках подсистемы управления портфелем прав на интеллектуальные активы руководитель принимает решение по следующим вопросам:

- выявляет интеллектуальные активы, которые подлежат правовой охране;

- определяет формы и методы охраны таких активов;

- юридически оформляет права на интеллектуальные активы; 
- разрабатывает мероприятия для защиты товарного рынка, на который ориентировано предприятие;

- формирует научно-технические направления и соответствующие им портфели патентов с акцентом на технических решениях, позволяющих повысить конкурентоспособность продукции.

Итак, рассмотренная система управления интеллектуальными активами на промышленном предприятии дает возможность конкретизировать, какие решения руководитель должен принимать в рамках той или иной подсистемы. При решении задач управлением интеллектуальными активами организации мы решаем и проблемы в управлении стоимостью, добавленной интеллектуальным капиталом, так как эти вещи взаимосвязаны.

В целом управление в современных организациях все больше ориентируется на использование умственных способностей работников и их нравственных устоев, что в совокупности с результатами мыслительной деятельности работников, воплощенных в виде организационных, технических, информационных, общественных достижений и связей организации, образует интеллектуальный капитал организации. 


\section{ГЛАВА З. ЭМПИРИЧЕСКОЕ ИССЛЕДОВАНИЕ ИНТЕЛЛЕКТУАЛЬНОЙ ДОБАВЛЕННОЙ СТОИМОСТИ ПРОМЫШЛЕННОГО ПРЕДПРИЯТИЯ}

\section{1. Разработка модели управления интеллектуальной добавленной стоимостью на промышленном предприятии}

Разработка модели оценки эффективности управления интеллектуальной добавленной стоимостью на предприятии является непростой задачей.

Для управления интеллектуальной добавленной стоимостью на предприятии за основу был взят процессный подход.

В соответствии с процессным подходом управление интеллектуальной добавленной стоимостью может быть представлено в виде системы бизнес-процессов. Процессный подход к управлению делегирует полномочия и ответственности через бизнеспроцессы [47]. Под бизнес-процессом будем понимать устойчивую, целенаправленную совокупность взаимосвязанных видов деятельности, которая по определенной технологии преобразует входы в выходы, представляющие ценность для потребителя [50].

Вход может быть представлен сырьем, составляющими частями, людьми, деньгами или информацией. Выход может быть в виде изделий, людей, получивших услугу, информации или комбинации этих элементов.

Предпосылкой для понимания любого решения является понимание контекста операций вход - процесс - выход.

При формулировке модели вход - выход необходимо решить три задачи:

1) определение входов и выходов;

2) определение источника входов и места назначения выходов; 
3) выяснение требований внутренних потребителей, которые обслуживаются выходами из процесса, и требований процесса для внутренних менеджеров, которые обеспечивают входы процесса. Для выявления бизнесов-процессов, которые лежат в основе управления интеллектуальной добавленной стоимости, обратимся к методике Анте Пулика «интеллектуальный коэффициент добавленной стоимости», суть данного метода подробно описана в параграфе 1.2.

В рамках процессного подхода рассмотрим модель процесса «управление интеллектуальной добавленной стоимостью на промышленном предприятии» как систему, включающую в себя несколько бизнес-процессов.

Такое структурирование позволит повысить эффективность управления интеллектуальной добавленной стоимостью, повысив при этом и коэффициент интеллектуальной добавленной стоимости по методике Пулика.

Модель управления интеллектуальной добавленной стоимостью на промышленном предприятии включает в себя следующие бизнес-процессы:

1) бизнес-процессы управления эффективностью человеческим капиталом;

2) бизнес-процессы управления эффективностью структурным капиталом;

3) бизнес-процессы управления эффективностью задействованным капиталом.

По сути, управление интеллектуальной добавленной стоимостью на предприятии сводится к поиску эффективного способа создания и использования знаний и информации для достижения целей компании. Управление эффективностью человеческого капитала в организации согласно концепции Я. Фиценца включает в себя пять ключевых бизнес-процессов: планирование, приобретение, содержание, развитие и сохранение [51]. 


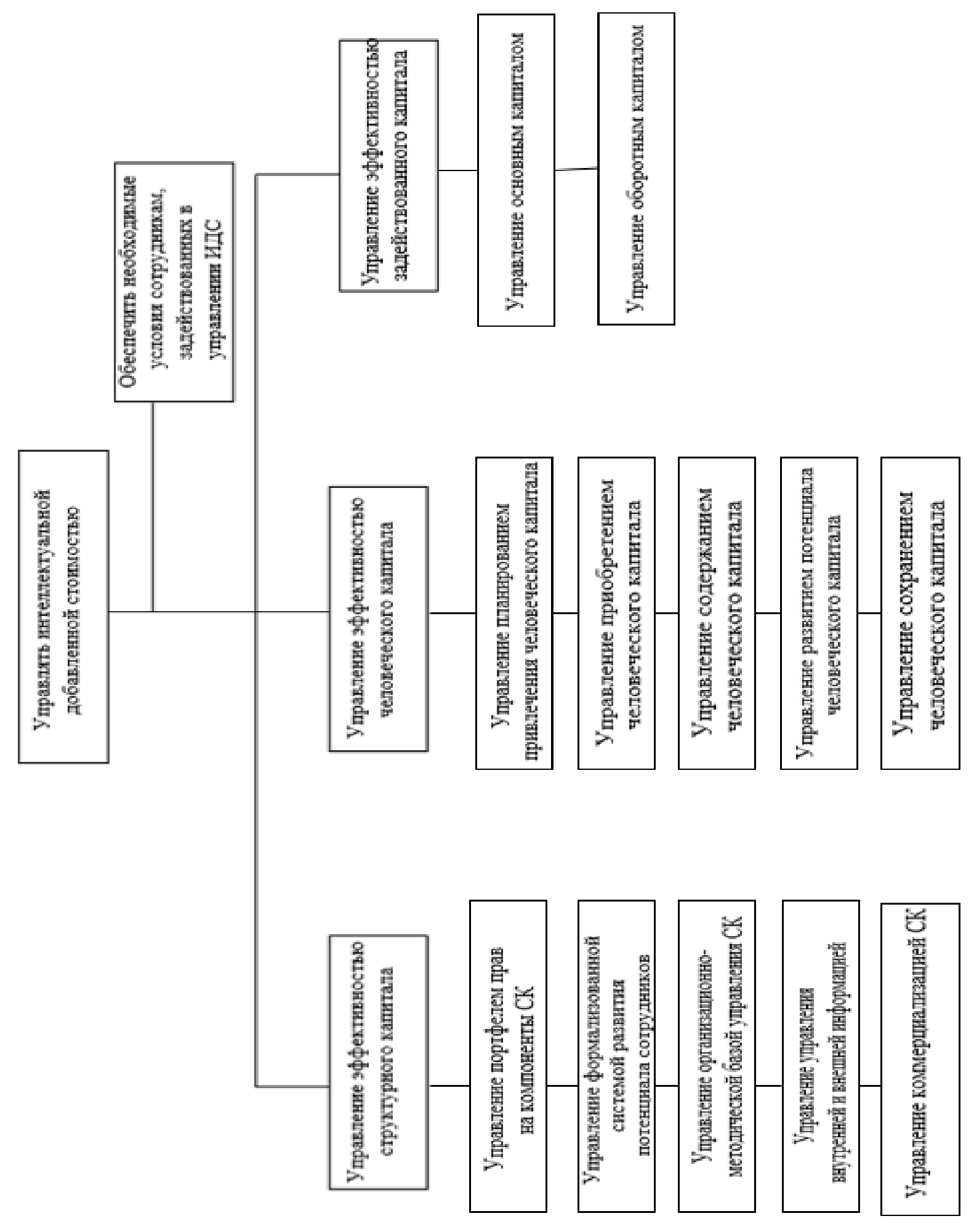

Рисунок 18. Модель управления интеллектуальной добавленной стоимостью на промышленном предприятии 5

${ }^{5}$ Составлено авторами по [1, 47, 49]. 
Рассмотрим каждый из их и выделим мероприятия, которые направлены на повышения интеллектуальной добавленной стоимости организации.

Бизнес-прочессы управления эффективностью человеческим капиталом включают в себя:

1) Планирование.

2) Приобретение.

3) Содержание.

4) Развитие.

5) Сохранение.

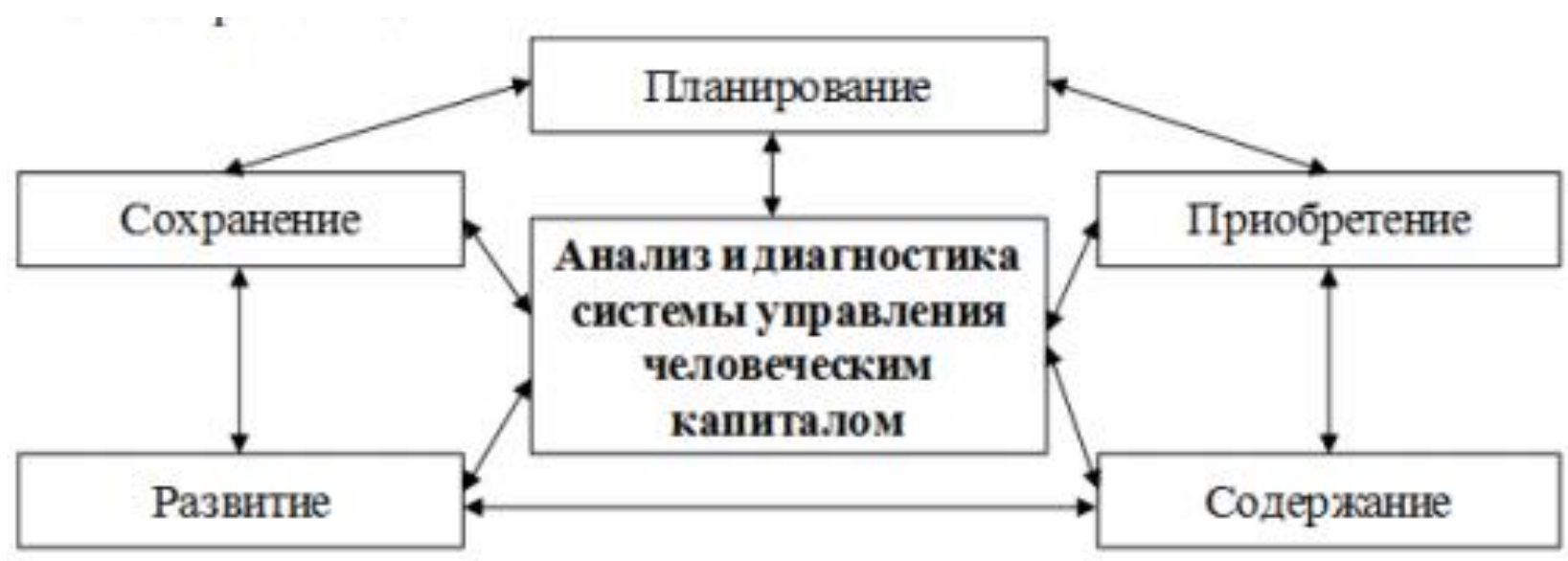

Рисунок 19. Модель формирования человеческого капитала в организации согласно Я. Фицеену [51]

Далее рассмотрим процесс управления структурным капиталом. Под процессом управления структурным капиталом промышленного предприятия будем понимать совокупность действий и мероприятий, которые направлены на обеспечение эффективного планирования, организации и контроля процессов формирования, развития и использования структурного капитала промышленного предприятия, а также мотивации процессов накопления и преумножения структурного капитала [47]. Таким образом, целью управления структурным капита- 
лом промышленного предприятия является достижение максимального результата от использования структурного капитала при оптимальном снижении затрат на него, которые возникают на различных стадиях разработки и реализации продукции.

- Бизнес-процессь управления эффективностью структурного капитала:

1) Подсистема управления формализованной системой развития потенциала сотрудников.

2) Подсистема управления организационно-методической базой управления структурным капиталом.

3) Подсистема управления внутренней и внешней информацией.

4) Подсистема управления портфелем прав на компоненты структурного капитала.

5) Подсистема управления коммерциализацией структурного капитала.

Далее рассмотрим бизнес-проиеессы управления эффективностью задействованного капитала, он состоит из управления:

- основным капиталом;

- оборотным капиталом.

В рамках управления оборотным и основным капиталом предприятия главной целью является максимизация прибыли на вложенный капитал при обеспечении устойчивой и достаточной платежеспособности предприятия.

Так как коэффициент интеллектуальной добавленной стоимости формируется за счет управления эффективностью 3 составляющих: человеческого, структурного и задействованного капиталов, то и мероприятия по управлению интеллектуальной добавленной стоимостью на предприятии будут опираться на управление этими компонентами. 


\section{2. Оценка интеллектуальной добавленной стоимости предприятия АО УЭМ}

Интеллектуальный капитал все более признается в качестве важного стратегического актива для достижения устойчивого конкурентного преимущества. Эффективное использование интеллектуального капитала позволяет компаниям получить конкурентное преимущество на рынке.

В пределах компании за счет увеличения объема производства, компания не обеспечит рост и развитие, для этого необходимо искать иные пути создания новой стоимости. На рынок необходимо выйти с «исключительным» продуктом, который позволит компании стать временным монополистом, получить сверхприбыль и покрыть все затраты. Для создания такого продукта необходимо разработать новые идеи и технологии, иметь в штате специалистов, обладающих знаниями и умениями, располагать необходимой информацией, то есть в компании должен быть построен интеллектуальный инструментарий, позволяющий определить её возможности по созданию и реализации инновационной продукции или услуги. На этом фоне в течение последних нескольких лет значительно возрос интерес к термину «интеллектуальный капитал».

Способность компании создать и эффективно использовать интеллектуальный капитал обеспечивает её благосостояние, конкурентоспособность, экономический рост и развитие, а также определяет результаты в будущем.

УЭМ - российское предприятие по электролитическому рафинированию меди и продукции из нее. Предприятие осуществляет полный производственный цикл: от переработки черновой меди и лома до выпуска продуктов из меди [41].

Основными видами деятельности предприятия является:

производство черновой меди; 
- огневое и электролитическое рафинирование меди;

- производство драгоценных и редких металлов;

- производство катодов медных;

- производство медной катанки;

- производство медного электролитического порошка и изделий из него;

производство медного купороса, никеля сернокислого, антисептика;

- производство свинца рафинированного;

- $\quad$ оказание услуг по горячему оцинкованию металлоизделий.

Ключевые стратегические задачи АО УЭМ [41]:

- $\quad$ развитие производственной системы с целью обеспечения конкурентоспособности продукции и услуг, оптимизации сырьевых, материальных, финансовых и информационных потоков;

развитие долгосрочных взаимовыгодных отношений с потребителями и внешними поставщиками;

предотвращение и сокращение негативного воздействия на окружающую среду;

стремление к нулевому уровню травматизма, предотвращение возникновения аварий на производстве;

- постоянное повышение энергетической эффективности.

Как и любое предприятие, АО УЭМ осознает и признает важность интеллектуального капитала как источника конкурентного преимущества, поэтому проведем оценку коэффициента интеллектуальной добавленной стоимости данного предприятия, используя для этой цели «коэффициент добавленной стоимости интеллектуального капитала» (VAIC). Все расчёты, представленные в работе, основы- 
ваются на годовой бухгалтерской (финансовой) отчетности АО УЭМ за 5-летний период (2013-2017 гг.), представленной в таблице 4.

Таблица 8. Показатели для расчета VAIC в АО УЭМ за 2013-2017 г2. ${ }^{6}$

\begin{tabular}{|l|c|c|c|c|c|}
\hline \multirow{2}{*}{ Показатель } & \multicolumn{5}{|c|}{ Период } \\
\cline { 2 - 6 } & 2013 & 2014 & 2015 & 2016 & 2017 \\
\hline $\begin{array}{l}\text { Выручка (Output), } \\
\text { млн руб. }\end{array}$ & 21337 & 20137 & 26052 & 28931 & 37170 \\
\hline $\begin{array}{l}\text { Себестоимость } \\
\text { (Input+HC), млн } \\
\text { руб. }\end{array}$ & 17512 & 18850 & 18311 & 22966 & 30674 \\
\hline $\begin{array}{l}\text { Затраты на опла- } \\
\text { ту труда (НС), } \\
\text { млн руб. }\end{array}$ & 3152 & 3292 & 3909 & 4565 & 4997 \\
\hline $\begin{array}{l}\text { Материальные } \\
\text { затраты (Inрut), } \\
\text { млн руб. }\end{array}$ & 14360 & 15558 & 14402 & 18401 & 25677 \\
\hline $\begin{array}{l}\text { Инвестированный } \\
\text { капитал (СЕ), млн } \\
\text { руб. }\end{array}$ & 29938 & 30510 & 32847 & 31605 & 33951 \\
\hline $\begin{array}{l}\text { Добавленная сто- } \\
\text { имость (VA), млн } \\
\text { руб. }\end{array}$ & 6977 & 4579 & 11650 & 10530 & 11493 \\
\hline
\end{tabular}

По данным таблицы 4 можно сказать, что добавленная стоимость (VA) на протяжении всех 5-ти лет имеет положительное значение с резким увеличением в 2015 году (что связано с ростом величины выручки на фоне снижающихся материальных затрат). Добавленная стоимость показывает увеличение совокупного дохода без учета затрат на оплату труда. Посмотрим каким образом данные значения скажутся на дальнейшем анализе.

${ }^{6}$ Составлено авторами по [52]. 
Таблица 9. Расчет VAIC АO УЭМ

\begin{tabular}{|c|c|c|c|c|c|}
\hline \multirow{2}{*}{ Показатель } & \multicolumn{5}{|c|}{ Период } \\
\cline { 2 - 6 } СЕE & 2013 & 2014 & 2015 & 2016 & 2017 \\
\hline HCE & 0,233 & 0,150 & 0,355 & 0,333 & 0,339 \\
\hline SCE & 2,214 & 1,391 & 2,980 & 2,307 & 2,300 \\
\hline VAIC & 0,548 & 0,281 & 0,664 & 0,566 & 0,565 \\
\hline
\end{tabular}

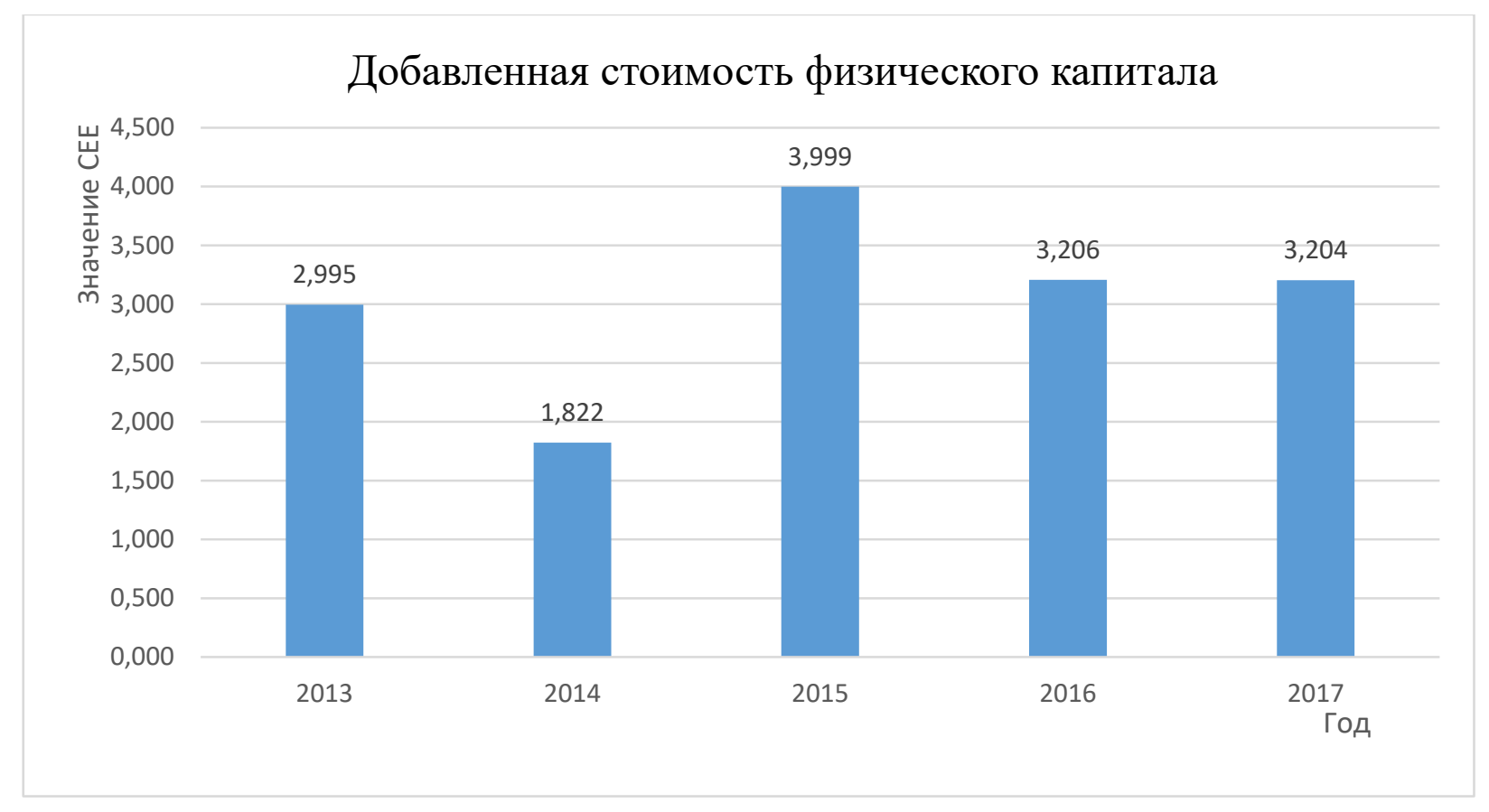

Рисунок 20. Добавленная стоимость физического капитала предприятия АО УЭМ 2013-2017 г2.

Дадим интерпретацию каждому показателю. Добавленная стоимость физического капитала (СЕЕ) показывает сколько добавленной стоимости создает одна единица физического капитала. Данный показатель с 2015 года держится почти на одном уровне: на 1 тысячу рублей задействованного физического капитала компания получала

${ }^{7}$ Составлено авторами по [52]. 
в среднем за 3 года 342 рубля добавленной стоимости.

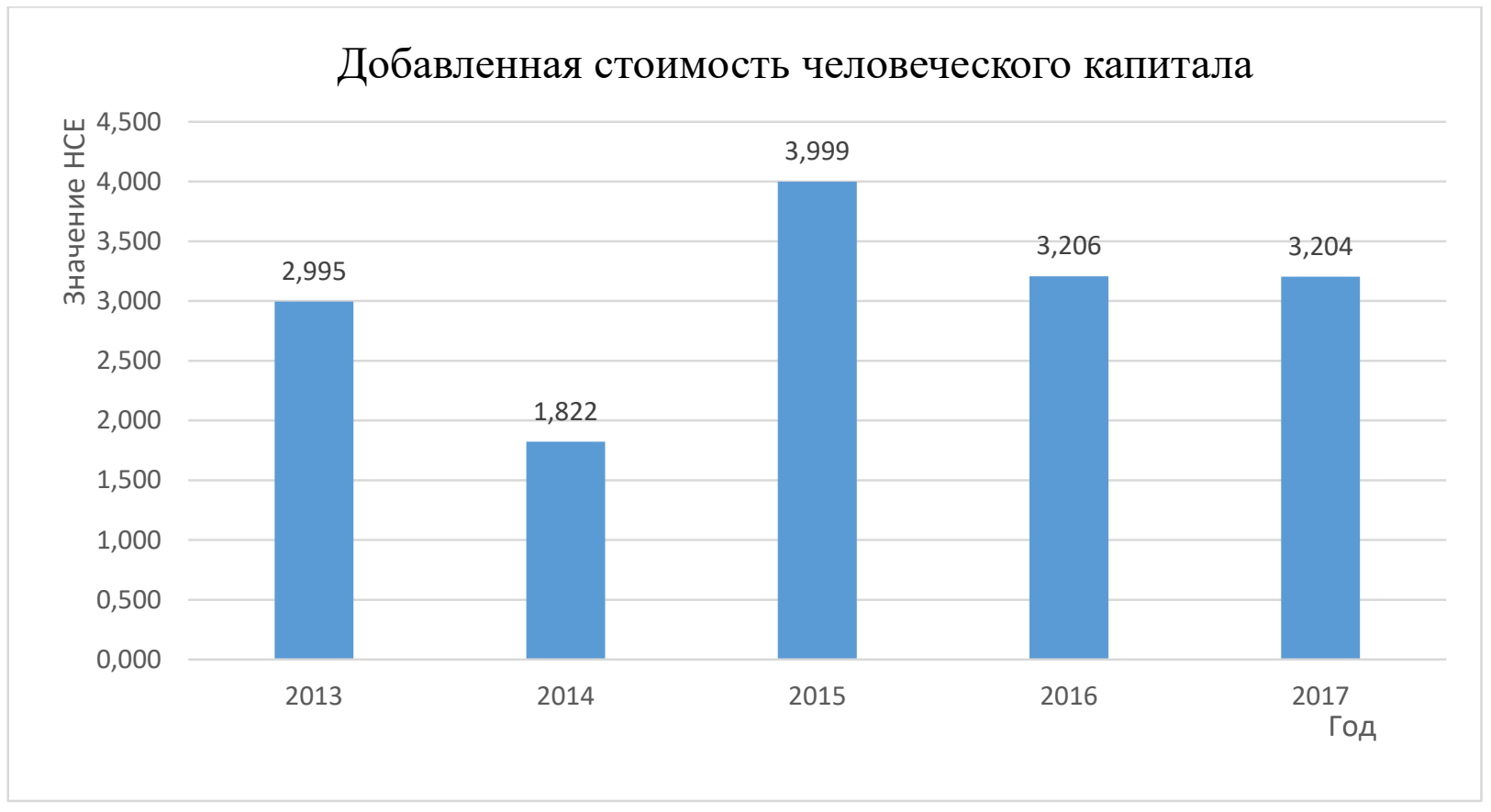

Рисунок 21. Добавленная стоимость человеческого капитала предприятия АО УЭМ за 2013-2017 г2.

Эффективность создания стоимости компании за счет человеческого капитала (HCE) показывает сколько добавленной стоимости создается на каждую денежную единицу, затраченную на сотрудников [6]. Наибольшая величина данного показателя наблюдается в 2015 году, интерпретировать которую можно следующим образом: 1 тысяча рублей, вложенная в человеческий капитал, принесла 2980 рублей добавленной стоимости. В 2016 года показатель НСЕ снизился до уровня, близкого к 2013 году.

Показатель эффективности создания стоимости компании за счет структурного капитала резко упал в 2014 году, но начиная с 2015 года вернул свои позиции. Таким образом, 1 тысяча рублей добавленной стоимости принесла в 2017 году 565 рублей структурного капитала. 


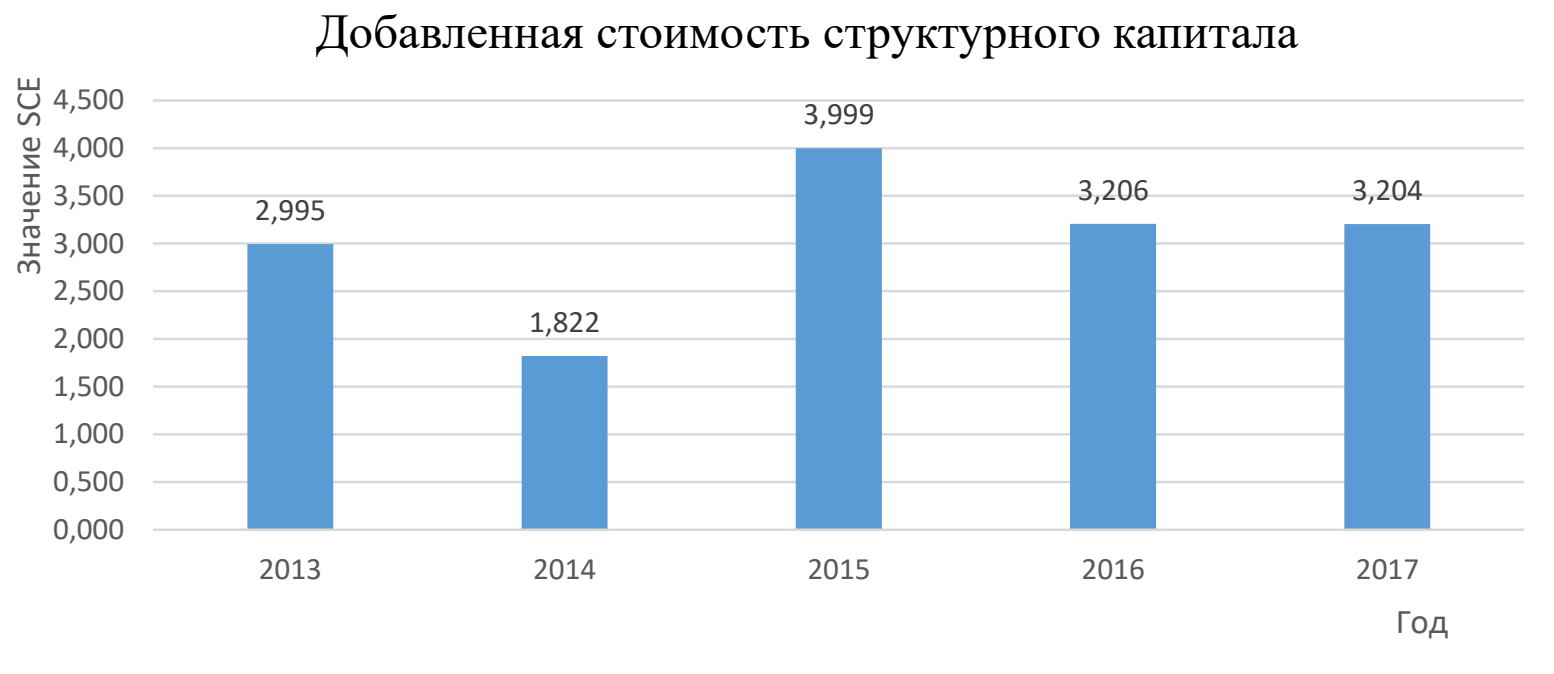

Рисунок 22. Добавленная стоимость человеческого капитала предприятия АО УЭМ за 2013-2017 г2.

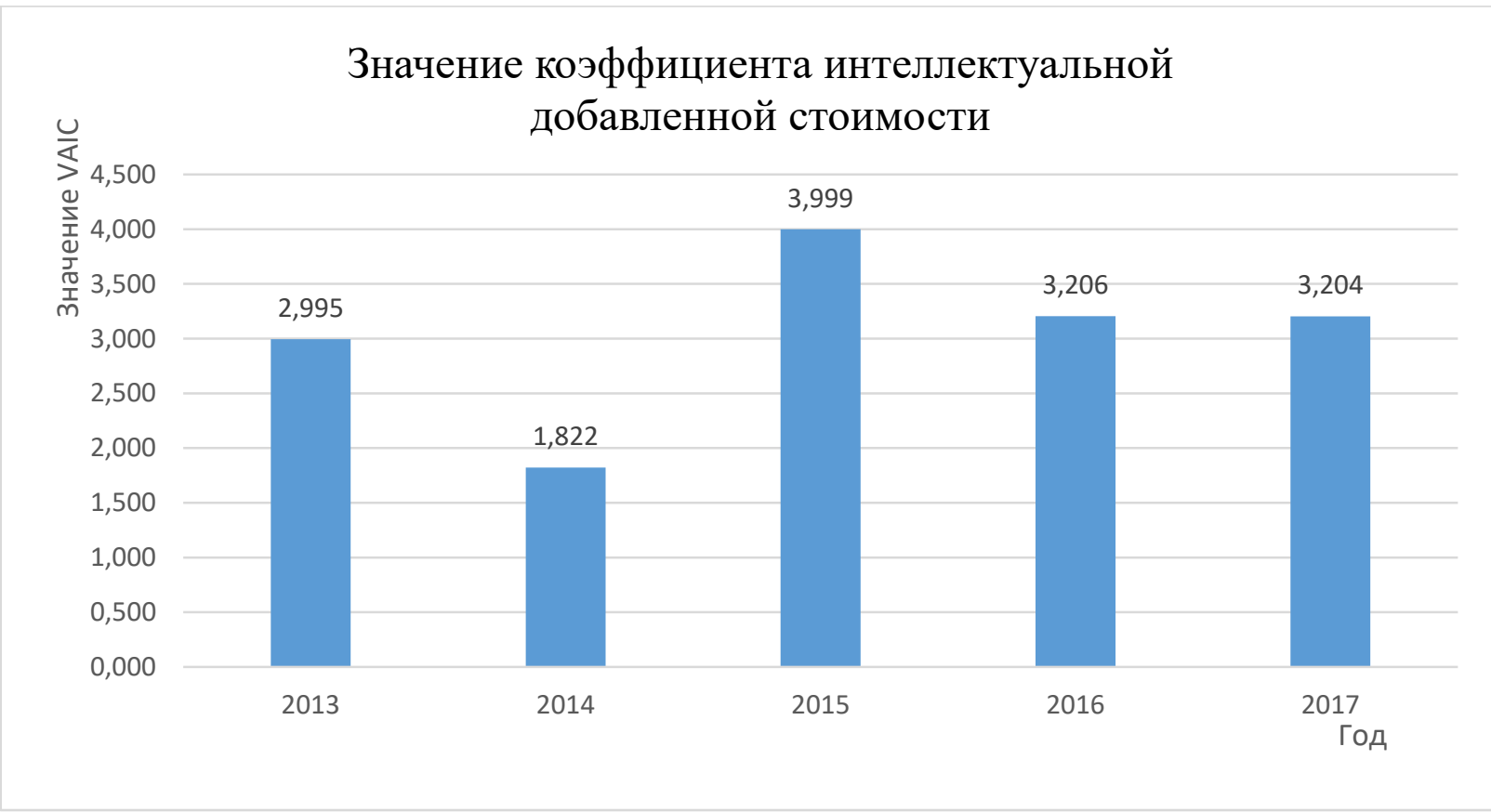

Рисунок 23. Коэффиииент интеллектуальной добавленной стоимости предприятия АО УЭМ за 2013-2017 г2.

Самым важным компонентом VAIC для АО УЭМ является показатель добавленной стоимости (эффективности) человеческого капитала НCE, который, несмотря на снижение в 2014 г., показывает более чем двухкратную отдачу от вложения в человеческие ресурсы. 
Структурный капитал является частью доли интеллектуального капитала, поэтому повышение доли структурного капитала говорит о повышении роли интеллектуального капитала на предприятии.

Подводя итог, согласно методу VAIC, общий вклад материальных и нематериальных активов АО УЭМ в добавленную стоимость компании в 2013 г. был равен 2995 руб., в 2014 г. он резко снизился до значения в 1822 руб., в 2015 г. вырос и достиг 3999 руб., далее снова уменьшился, и в 2017 г. добавленная стоимость составила 3204 руб. на 1 тыс. руб. вложенных активов. Отметим, что ценность бизнеса во многом определяется его интеллектуальными и информационными ресурсами, и на сегодняшний день большая часть активов компаний имеет нематериальный характер.

\section{3. Разработка мероприятий по управлению интеллектуальной добавленной стоимостью на примере АО УЭМ}

Организационная структура управления предприятием отражает состав и подчиненность линейных и функциональных звеньев управления, в АО УЭМ структура управления имеет линейнофункциональный вид.

Директору ОА УЭМ подчиняются:

1) Главный инженер во главе отдела материально-технического обеспечения, который определяет техническую политику, пути реконструкции и технического перевооружения действующего производства, уровень его специализации и диверсификации.

2) Директор по коммерческим вопросам во главе финансового отдела, который определяет финансово-хозяйственную политику предприятия и стратегию коммерческой деятельности, руководит транспортным обслуживанием и договорной работой.

3) Директор по строительству и реконструкции, который отве- 
чает за разработку и реализацию инвестиционных проектов по перспективному развитию предприятия, планов технического перевооружения и реконструкции производства.

4) Директор по безопасности и правовым вопросам во главе службы охраны, который отвечает за правовое сопровождение деятельности предприятия и защиту его законных прав и интересов.

5) Директор по общим вопросам во главе юридического отдела, который отвечает за взаимодействие с законодательными и исполнительными органами власти, контролирует социальную политику и реализацию социальных проектов.

6) Директор по работе с персоналом во главе отдела кадров, который определяет стратегию управления персоналом, кадровую политику предприятия.

7) Директор по информационным технологиям.

8) Директор по международным связям, который отвечает за развитие международных связей с иностранными компаниями и продвижение положительного международного имиджа и интересов АО УЭМ.

Подразделения, явно направленного на управление интеллектуальной добавленной стоимостью, нет, но для усиления предприятия на рынке, для увеличения конкурентоспособности организации, увеличения добавленной стоимости, добавленной интеллектуальным капиталом, предприятию необходимо рассмотреть вариант формирования данного подразделения.

Модель по управлению интеллектуальной добавленной стоимостью на промышленном предприятии представлена в параграфе 3.1. Теперь рассмотрим, как в рамках данной модели можно управлять интеллектуальной добавленной стоимостью на предприятии АО УЭМ. 


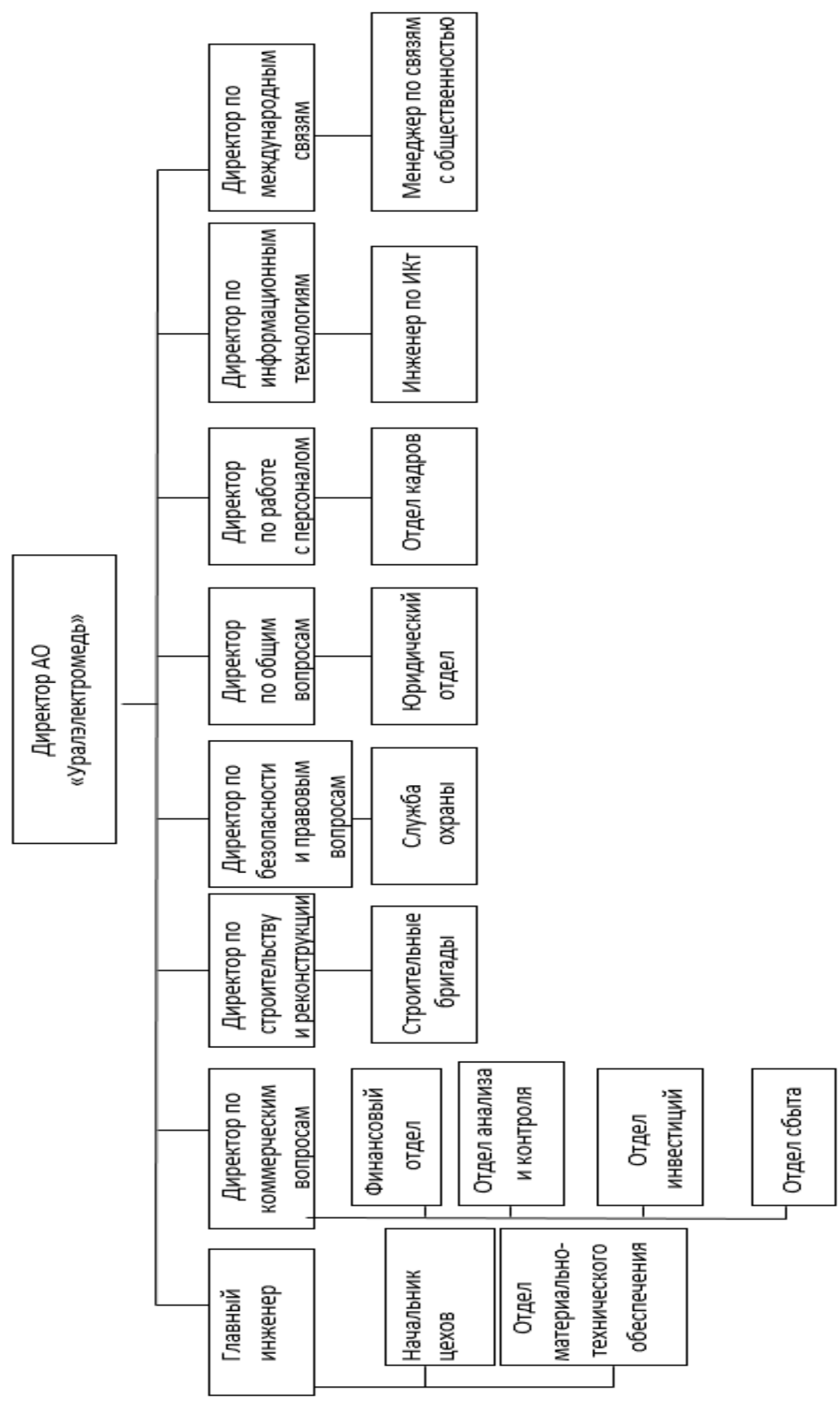

Рисунок 24. Организационная структура АО УЭМ [41] 
В рамках управления интеллектуальной добавленной стоимостью на АО УЭМ рассмотрены бизнес-процессы управлением интеллектуальной добавленной стоимостью, определены входы и входы и расписаны мероприятия в рамках бизнес-процессов, которые помогут повысить эффективность управления интеллектуальной добавленной стоимостью на предприятии и повысить конкурентоспособность предприятия.

Рассмотрим бизнес-процессы управления эффективностью человеческим капиталом на АО УЭМ. В целом, исходя из оценки коэффициента интеллектуальной добавленной стоимости на данном предприятии, человеческий капитал показывает двукратную отдачу от вложения в человеческие ресурсы, что является хорошим результатом.

Цель первого бизнес-процесса «Планирование человеческого капитала» на АО УЭМ - это определение целей развития направления, планирование и организация деятельности для их достижения (таблица 10).

Планирование потребности в человеческом капитале должно начинаться с анализа демографических показателей населения, в нашем случае это Свердловская область; анализа показателей развития системы профессионального образования, здравоохранения и социального обеспечения. Данные показатели помогут организации иметь представление о предложении на рынке, например, среди выпускников с различными квалификациями при разработке стратегии обновления кадрового обновления предприятия. Одним из важнейших направлений в планировании человеческого капитала является мониторинг статистики о занятости населения на рабочих местах в промышленности, о накопленном потенциале сотрудников и тенденциях в его движении. На основании всех этих показателей в совокупности формируется стратегия и политика управления персоналом на предприятии; разрабатываются профессиональные стандарты для различных групп сотрудников на промышленном предприятии. 
Таблица 10. Сущность бизнес-процесса «Планирование привлечения человеческого капитала» на АО УЭМ в модели процесса «управление интеллектуальной добавленной стоимостью»

\begin{tabular}{|c|c|c|}
\hline Входы & $\begin{array}{c}\text { Деятельность в рамках } \\
\text { процедуры }\end{array}$ & Выходы \\
\hline $\begin{array}{l}\text { Стратегический } \\
\text { анализ внешней } \\
\text { среды }\end{array}$ & $\begin{array}{l}\text { - Анализ демографических } \\
\text { показателей населения. } \\
\text { - Анализ показателей разви- } \\
\text { тия региональной и нацио- } \\
\text { нальной системы професси- } \\
\text { онального образования, } \\
\text { здравоохранения и социаль- } \\
\text { ного обеспечения. } \\
\text { - Мониторинг статистики о } \\
\text { занятости населения на ра- } \\
\text { бочих местах в промышлен- } \\
\text { ности. } \\
\text { - Анализ сведений о безрабо- } \\
\text { тице в регионе. } \\
\text { - Демонстрация предприятия } \\
\text { для потенциальных соиска- } \\
\text { телей как привлекательного } \\
\text { для работы. } \\
\text { - Анализ заявительных до- } \\
\text { кументов и отбор новых } \\
\text { профессионально пригодных } \\
\text { работников }\end{array}$ & $\begin{array}{l}\text { - Знание объема предложе- } \\
\text { ния на рынке труда. } \\
\text { - Формирование политики } \\
\text { управления персоналом. } \\
\text { - Формирование стратегии } \\
\text { управления человеческим } \\
\text { капиталом. } \\
\text { - Разработка профессио- } \\
\text { нальных стандартов для } \\
\text { различных групп сотрудни- } \\
\text { ков на промышленном } \\
\text { предприятии }\end{array}$ \\
\hline
\end{tabular}

После формирования стратегии и политики управления персоналом организация нацеливается на приобретение человеческого капитала (см. таблицу 11). 
Таблища 11. Сущуность бизнес-прочесса «Приобретение человеческого капитала» в модели прочесса «управление интеллектуальной добавленной стоимостью»

\begin{tabular}{|c|c|c|}
\hline Входы & $\begin{array}{c}\text { Деятельность в рамках } \\
\text { процедуры }\end{array}$ & Выходы \\
\hline $\begin{array}{l}\text { Знание объема } \\
\text { предложения на } \\
\text { рынке труда }\end{array}$ & $\begin{array}{l}\text { - Оценка уровня человеческого } \\
\text { капитала кандидатов и его } \\
\text { эффективности. } \\
\text { - Отбор кандидатов на соответ- } \\
\text { ствующие должности. } \\
\text { - Определение принципов найма } \\
\text { кандидатов или переквалифика- } \\
\text { ции сотрудников }\end{array}$ & $\begin{array}{l}\text { - Приобретение рабочей } \\
\text { силы. } \\
\text { - Приобретение пред- } \\
\text { приятием человеческого } \\
\text { капитала }\end{array}$ \\
\hline
\end{tabular}

Главным мероприятием в рамках данного бизнес-процесса является отбор кандидатов на соответствующие должности. Для этого необходимо оценить уровень человеческого капитала потенциальных кандидатов и то, насколько эффективно он использовался кандидатами, опираясь на их предшествующий опыт. Кадровые стратегии должны определить принцип найма кандидатов или переквалификацию сотрудников, для этого нужно учитывать ситуацию на внешнем и внутреннем рынке. Так, оценив предложение на рынке труда, организация должна принять решение: нанимать новых кандидатов извне либо переобучить старых, если наблюдается дефицит талантов.

После приобретения человеческого капитала организация должна компенсировать знания, умения, навыки и способности сотрудников путем установления справедливых вознаграждений в зависимости от эффективного использования индивидуального человеческого капитала и обеспечить разумные уровни льгот, это один из самых весомых инструментов в современном менеджменте. Вознаграждениями могут быть достойная заработная плата, премии за вы- 
полнения плана, социальный пакет, оплата путевок в санатории или скидка для сотрудников и их детей на определенные развлекательные мероприятия.

Цель бизнес-процесса «Содержание человеческого капитала» это эффективное использование индивидуального человеческого капитала на промышленном предприятии для повышения конкурентоспособности предприятия (таблица 12).

Таблиц̧а 12. Сущзность бизнес-процуесса «Содержсание человеческого капитала» в модели прочесса «управление интеллектуальной добавленной стоимостью»

\begin{tabular}{|c|c|c|}
\hline Входы & $\begin{array}{c}\text { Деятельность в рамках } \\
\text { процедуры }\end{array}$ & Выходы \\
\hline $\begin{array}{l}\text { Компетенция, } \\
\text { знания, умения, } \\
\text { навыки способно- } \\
\text { сти сотрудников }\end{array}$ & $\begin{array}{l}\text { - Компенсация трудовых затрат } \\
\text { сотрудников с помощью заработны } \\
\text { плат и выплат. } \\
\text { - Установление справедливых воз- } \\
\text { награждений, премий за эффектив- } \\
\text { ное использование человеческого } \\
\text { капитала }\end{array}$ & $\begin{array}{l}\text { Эффективное исполь- } \\
\text { зование индивидуаль- } \\
\text { ного человеческого } \\
\text { капитала на АО УЭМ }\end{array}$ \\
\hline
\end{tabular}

Далее потенциал сотрудников на предприятии АО УЭМ должен развиваться. Цель бизнес-процесса «Развитие потенциала человеческого капитала» - повышение эффективности человеческого капитала с помощью повышения квалификации сотрудников (таблица 13). В рамках данного бизнес-процесса должны проводиться такие мероприятия, как: повышение квалификации работников путем обучения сотрудников: тренинги, семинары, мастер-классы; разработка системы оценки эффективности обучения сотрудников.

Цель бизнес-процесса «Сохранение человеческого капитала на АО УЭМ» - повышение конкурентоспособности предприятия, увеличение интеллектуальной добавленной стоимости промышленного предприятия. 
Таблица 13. Сущуность бизнес-прочесса «Развитие потенщиала человеческого капитала» в модели прочесса «управление интеллектуальной добавленной стоимостью»

\begin{tabular}{|l|l|l|}
\hline \multicolumn{1}{|c|}{ Входы } & \multicolumn{1}{|c|}{ Деятельность в рамках процедуры } & \multicolumn{1}{|c|}{ Выходы } \\
\hline $\begin{array}{l}\text { Компетенция, зна- } \\
\text { ния, умения, навы- } \\
\text { ки способности со- } \\
\text { трудников }\end{array}$ & $\begin{array}{l}\text { путем обучения сотрудников: тренинги, } \\
\text { семинары, мастер-классы. }\end{array}$ & $\begin{array}{l}\text { Высококвалифи- } \\
\text { цированный пер- } \\
\text { - Разработка системы оценки эффектив- } \\
\text { ности обучения сотрудников }\end{array}$ \\
\hline
\end{tabular}

В рамках бизнес-процесса «Сохранение талантов» в организации должна быть разработана программа исследования удовлетворенности сотрудников рабочим местом путем опросов, анкетирования, интервью при увольнении сотрудников. Как следствие, в организации должна быть выработанная стратегия сохранения талантов, это дает организации снизить расходы на рекрутинг и обучение новых сотрудников (таблица 14).

Таблища 14. Сущуность бизнес-прочуесса «Сохранение человеческого капитала» на АО УЭМ в модели процесса «управление интеллектуальной добавленной стоимостью»

\begin{tabular}{|l|l|l|}
\hline \multicolumn{1}{|c|}{ Входы } & \multicolumn{1}{|c|}{ Деятельность в рамках процедуры } & \multicolumn{1}{c|}{ Выходы } \\
\hline Компетенция, зна- & Разработка программ исследования & - Выработанная страте- \\
ния, умения, навы- & удовлетворенности сотрудников ра- & гия сохранения талан- \\
ки способности со- & бочим местом путем опросов, анке- & тов. \\
трудников & тирования, интервью при увольнении & - Снижение расходов на \\
& сотрудников & рекрутинг, на обучение \\
& & новых работников. \\
& & $\begin{array}{l}\text { Повышение конкурен- } \\
\text { тоспособности предпри- } \\
\end{array}$ \\
\end{tabular}

Искусство управления командой, ее наиболее результативными сотрудниками - одна из наиболее важных задач руководителя, еe результатом является эффективность использования человеческого по- 
тенциала. Инвестиции в человеческий капитал имеют высокий уровень окупаемости и рентабельности, поэтому нужно уметь управлять бизнес-процессами эффективности человеческого капитала на промышленном предприятии.

Далее в нашей модели должны быть рассмотрены бизнеспроцессы управления эффективностью структурным капиталом. Структурный капитал заключён в знаниях, которые «принадлежат организации»: технология, изобретения, патенты, ноу-хау, процессы, системы, структура и внутренние правила, стратегия и культура компании.

Основные задачи управления структурным капиталом промышленного предприятия выглядят следующим образом:

1. Планирование, организация, контроль, мотивация и регулирование процессов формирования и развития структурного капитала.

2. Планирование, организация, контроль и регулирование процессов использования структурного капитала внутри предприятия, а также во внешней среде.

3. Образование инновационно-восприимчивой среды, создающей условия для развития сотрудников, их мотивация к накоплению и преумножению структурного капитала.

4. Формирование и развитие для дальнейшего эффективного использования организационно-методической основы управления структурным капиталом.

5. Планирование, организация, контроль и регулирование процесса формализованной информатизации как внутри предприятия, так и между внешней средой и предприятием.

6. Планирование, организация и контроль процесса формирования прав на объекты интеллектуальной собственности.

Продукция, производимая промышленным предприятием в 
условиях жесткой конкуренции имеет некоторые факторы, которые осложняют процесс управления структурным капиталом:

- необходимость подготовки высококвалифицированных специалистов для различных направлений деятельности: управленческой, научной и производственной;

- $\quad$ потребность в инвестициях в процесс создания структурного капитала, его развития, поддержания в силе исключительных прав и выработка мер для пресечения недобросовестной конкуренции;

- необходимость развития информатизации бизнеспроцессов, включая создание разветвленных баз, данных и других программных продуктов, позволяющих контролировать процесс управления структурным капиталом;

- многообразие компонентов структурного капитала;

- сложность определения рыночной стоимости некоторых видов структурного капитала;

- $\quad$ высокая степень риска при принятии управленческих решений в области управления структурным капиталом;

- необходимость постоянного отслеживания бизнеспространства, защищенного патентами, что приводит к возможности нарушения прав конкурентов и появлению дополнительных издержек;

- $\quad$ необходимость координации различных функций управления структурным капиталом в процессе создания и производства продукции промышленного предприятия;

- постоянное развитие инновационных процессов, ведущее к быстрому обновлению всех видов продукции предприятия, что отражается во внесении постоянных корректировок в организационное обеспечение процесса управления структурным капиталом;

- $\quad$ продолжительное время патентования объектов промыш- 
ленной собственности.

Первой подсистемой в бизнес-процессе управления эффективностью структурным капиталом является подсистема управления формализованной системой развития потенциала сотрудников (таблица 15).

Таблица 15. Сущность подсистемы управления формализованной системой развития потенциала сотрудников АО УЭМ в модели процесса «управление интеллектуальной добавленной стоимостью»

\begin{tabular}{|l|l|l|}
\hline \multicolumn{1}{|c|}{ Входы } & \multicolumn{1}{|c|}{$\begin{array}{c}\text { Мероприятия в рамках } \\
\text { бизнес-процесса }\end{array}$} & \multicolumn{1}{|c|}{ Выходы } \\
Портфели инфор- & - Создание и эффективное & - Информация о стоимости \\
интеллектуальных & использование формализо- & формализованных инфор- \\
продуктов & ванных фондов знаний. & мационно-интеллектуа- \\
& - Прогнозирование потреб- & льных продуктов. \\
ности в формализованных & - Сведения об использова- \\
фондах знаний. & нии формализованных ин- \\
& - Увеличение производи- & формационно-интеллек- \\
& тельности сотрудников в & туальных продуктов \\
& сфере интеллектуального & \\
& труда за счет использования & \\
формализованных фондов & \\
& знаний. \\
& - Поощрение инициативной & \\
& работы в области развития & \\
& формализованных фондов & \\
& знаний \\
\hline
\end{tabular}

Входом подсистемы управления формализованной системой развития потенциала сотрудников являются портфели информационноинтеллектуальных продуктов. Функции, которые выполняет данная подсистема, - это создание и эффективное использование формализованных фондов знаний; увеличение производительности сотрудников в сфере интеллектуального труда; прогнозирование потребности в 
формализованных фондах знаний; поощрение сотрудников.

Следующая подсистема управления структурным капиталом на предприятии АО УЭМ согласовывает деятельность сотрудников и создает единую интеллектуально-информационную систему предприятия, установив права и ответственность сотрудников при ее применении (таблица 16).

Таблица 16. Сущность подсистемы управления организационнометодической базой управления структурным капиталом в модели процесса «управление интеллектуальной добавленной стоимостью»

\begin{tabular}{|c|c|c|}
\hline Входы & $\begin{array}{l}\text { Мероприятия в рамках } \\
\text { бизнес-процесса }\end{array}$ & Выходы \\
\hline $\begin{array}{l}\text { Организационно- } \\
\text { методическая база } \\
\text { управлением СК АО } \\
\text { УЭМ }\end{array}$ & $\begin{array}{l}\text { - Координация действий } \\
\text { всех специалистов, кото- } \\
\text { рые задействованы в про- } \\
\text { цессе управления СК. } \\
\text { - Регламентация и форма- } \\
\text { лизация различных про- } \\
\text { цессов и процедур управ- } \\
\text { ления СК, представления } \\
\text { их в виде оформленных } \\
\text { документов }\end{array}$ & $\begin{array}{l}\text { - Согласованность дея- } \\
\text { тельности сотрудников. } \\
\text { - Создание единой интел- } \\
\text { лектуально-информацион- } \\
\text { ной системы предприя- } \\
\text { тия; установка прав и от- } \\
\text { ветственности сотрудни- } \\
\text { ков при ее применении }\end{array}$ \\
\hline
\end{tabular}

Следующая подсистема - подсистема управления внутренней и внешней информацией АО УЭМ. Для достижения целей в управлении информацией осуществляется процесс выбора для использования внутри организации приемлемого программного обеспечения и соответствующей технической базы, накопления и развития знаний о технологиях программирования, обеспечение бесперебойной работы пользователей с информационной средой. 
Таблища 17. Сущчность подсистемы управления внутренней и внешней информацией в модели процесса «управление интеллектуальной добавленной стоимостью»

\begin{tabular}{|c|c|c|}
\hline Входы & $\begin{array}{l}\text { Мероприятия в рамках } \\
\text { бизнес-процесса }\end{array}$ & Выходы \\
\hline $\begin{array}{l}\text { - Направления раз- } \\
\text { вития и использо- } \\
\text { вания информаци- } \\
\text { онно-интеллекту- } \\
\text { альных ресурсов. } \\
\text { - Портфели ин- } \\
\text { формационно-ин- } \\
\text { теллектуальных } \\
\text { продуктов АО } \\
\text { УЭМ }\end{array}$ & $\begin{array}{l}\text { - Формирование системы мето- } \\
\text { дов и способов сбора, обработ- } \\
\text { ки, накопления, передачи, хра- } \\
\text { нения и дальнейшего использо- } \\
\text { вания внутренней и внешней } \\
\text { информации соответственно. } \\
\text { - Разработка технологий полу- } \\
\text { чения, обработки и анализа, } \\
\text { дальнейшей интерпретации } \\
\text { первичной информации. } \\
\text { - Формирование и развитие ин- } \\
\text { формационной базы предприя- } \\
\text { тия, проектирование информа- } \\
\text { ционных потоков, разработка } \\
\text { способов и методов рациональ- } \\
\text { ного использования информа- } \\
\text { ци, определение оптимального } \\
\text { размера информации, ее струк- } \\
\text { турирование для обеспечения } \\
\text { эффективной деятельности } \\
\text { предприятия. } \\
\text { - Выбор для использования } \\
\text { внутри организации приемле- } \\
\text { мого программного обеспече- } \\
\text { ния и соответствующей техни- } \\
\text { ческой базы, накопления и раз- } \\
\text { вития знаний о технологиях } \\
\text { программирования, обеспече- } \\
\text { ние бесперебойной работы } \\
\text { пользователей с информацион- } \\
\text { ной средой }\end{array}$ & $\begin{array}{l}\text { Сохранность инфор- } \\
\text { мации и повышение } \\
\text { эффективности ис- } \\
\text { пользования форма- } \\
\text { лизованных инфор- } \\
\text { мационно- } \\
\text { интеллектуальных } \\
\text { продуктов }\end{array}$ \\
\hline
\end{tabular}


При управлении внешней информацией возникают определенные трудности в сборе и анализе информации, так как нужен постоянный контроль изменения факторов внешней среды, необходимы мероприятия по пресечению утечки коммерческой информации во внешнюю среду. Более подробно мероприятия рассмотрены в таблице 17.

Проводимые мероприятия в рамках подсистемы управления внутренней и внешней информацией позволяют обеспечить необходимую сохранность информации на предприятии АО УЭМ и повысить эффективность ее использования.

В рамках подсистемы управления портфелем прав на компоненты структурного капитала предприятия проводится оптимизация портфеля прав на компоненты структурного капитала согласно политике организации в области создания и использования структурного капитала, а также патентной политике АО УЭМ (таблица 18).

В ходе следующей подсистемы управления портфелем прав происходят анализ и оценка рыночной стоимости прав на объекты интеллектуальной собственности, после чего разрабатывается стратегия и выявляются направления коммерческого использования компонентов структурного капитала промышленного предприятия (таблица 19).

В рамках управления оборотным и основным капиталом предприятия главной целью является в общем случае максимизация прибыли на вложенный капитал при обеспечении устойчивой и достаточной платежеспособности предприятия АО УЭМ (таблицы 20, 21). 
Таблица 18. Сущность подсистемы управления портфелем прав на компоненты структурного капитала в модели процеесса «управление интеллектуальной добавленной стоимостью»

\begin{tabular}{|c|c|c|}
\hline Входы & $\begin{array}{c}\text { Мероприятия в рамках } \\
\text { бизнес-процесса }\end{array}$ & Выходы \\
\hline $\begin{array}{l}\text { Портфели прав } \\
\text { на компоненты } \\
\text { СК }\end{array}$ & $\begin{array}{l}\text { - Выявление компонентов СК, } \\
\text { которые подлежат правовой } \\
\text { охране. } \\
\text { - Определение способов охра- } \\
\text { ны. } \\
\text { - Организация юридического } \\
\text { оформления прав на них. } \\
\text { - Разработка различных органи- } \\
\text { зационно-технических меро- } \\
\text { приятий, обеспечивающих за- } \\
\text { щиту товарного рынка. } \\
\text { - Пресечение недобросовестной } \\
\text { конкуренции. } \\
\text { - Создание научно-технических } \\
\text { направлений и соответствую- } \\
\text { щих им портфелей }\end{array}$ & $\begin{array}{l}\text { Разработанная грамот- } \\
\text { ная патентная политика } \\
\text { на предприятии }\end{array}$ \\
\hline
\end{tabular}

Таблица 19. Сущность подсистемы управления коммерииализацией структурного капитала на АО УЭМ в модели процесса «управление интеллектуальной добавленной стоимостью»

\begin{tabular}{|c|c|c|}
\hline Входы & $\begin{array}{c}\text { Мероприятия в рамках } \\
\text { бизнес-процесса }\end{array}$ & Выходы \\
\hline $\begin{array}{l}\text { Объекты интеллек- } \\
\text { туальной соб- } \\
\text { ственности АО } \\
\text { УЭМ }\end{array}$ & $\begin{array}{l}\text { - Анализ и оценка рыночной } \\
\text { стоимости прав на объекты } \\
\text { интеллектуальной собствен- } \\
\text { ности АО УЭМ. } \\
\text { - Мониторинг коммерческо- } \\
\text { го потенциала компонентов } \\
\text { структурного капитала }\end{array}$ & $\begin{array}{l}\text { - Разработана стратегия } \\
\text { и выработаны направле- } \\
\text { ния коммерческого ис- } \\
\text { пользования компонен- } \\
\text { тов СК на АО УЭМ. } \\
\text { - Выявлена выгода от } \\
\text { использования компо- } \\
\text { нентов СК }\end{array}$ \\
\hline
\end{tabular}


Таблица 20. Сущность бизнес-процесса управления основным капиталом предприятия АО УЭМ в модели процесса «управление интеллектуальной добавленной стоимостью»

\begin{tabular}{|c|c|c|}
\hline Входы & $\begin{array}{l}\text { Мероприятия в рамках } \\
\text { бизнес-процесса }\end{array}$ & Выходы \\
\hline $\begin{array}{l}\text { Капитал, материа- } \\
\text { лизованный в зда- } \\
\text { ниях, сооружениях, } \\
\text { станках и в другом } \\
\text { оборудовании, ко- } \\
\text { торое функциони- } \\
\text { рует в процессе } \\
\text { производства не- } \\
\text { сколько лет и об- } \\
\text { служивает несколь- } \\
\text { ко производствен- } \\
\text { ных циклов }\end{array}$ & $\begin{array}{l}\text { - Выявление и удовлетворение } \\
\text { потребности в конкретных } \\
\text { элементах основного капитала. } \\
\text { - Поддержание оптимальной } \\
\text { пропорциональности между } \\
\text { составными частями основно- } \\
\text { го капитала. } \\
\text { - Ускорение оборота основно- } \\
\text { го капитала в процессе его ис- } \\
\text { пользования. } \\
\text { - Выбор наиболее прогрессив- } \\
\text { ных видов основного капитала } \\
\text { с позиций обеспечения роста } \\
\text { рыночной стоимости компа- } \\
\text { нии }\end{array}$ & $\begin{array}{l}\text { - Максимизация ко- } \\
\text { нечного финансового } \\
\text { результата деятельно- } \\
\text { сти предприятия АО } \\
\text { УЭМ. } \\
\text { - Разработка политики } \\
\text { управления основным } \\
\text { капиталом АО УЭМ }\end{array}$ \\
\hline
\end{tabular}


Таблица 21. Сущность бизнес-процесса управления оборотным капиталом предприятия АО УЭМ в модели процесса «управление интеллектуальной добавленной стоимостью»

\begin{tabular}{|c|c|c|}
\hline Входы & $\begin{array}{l}\text { Мероприятия в рамках бизнес- } \\
\text { процесса }\end{array}$ & Выходы \\
\hline $\begin{array}{l}\text { Производственные } \\
\text { фонды, полностью } \\
\text { используемые в те- } \\
\text { чение одного про- } \\
\text { изводственного } \\
\text { цикла: запасы сы- } \\
\text { рья, материалов, } \\
\text { полуфабрикатов }\end{array}$ & $\begin{array}{l}\text { - Расчет минимально достаточ- } \\
\text { ных средств для авансирования } \\
\text { оборотных активов с целью бес- } \\
\text { перебойной и ритмичной работы } \\
\text { предприятия. } \\
\text { - Выработка учетной политики } \\
\text { предприятия для оптимизации } \\
\text { налогообложения путем выбора } \\
\text { методов амортизации, списания } \\
\text { ТМЦ, определения выручки от } \\
\text { реализации и т.д. } \\
\text { - Ускорение оборачиваемости } \\
\text { оборотных средств на каждой } \\
\text { стадии оборота капитала }\end{array}$ & $\begin{array}{l}\text { - Максимизация } \\
\text { конечного финан- } \\
\text { сового результата } \\
\text { деятельности } \\
\text { предприятия АО } \\
\text { УЭМ. } \\
\text { - Разработана по- } \\
\text { литика управления } \\
\text { оборотными акти- } \\
\text { вами предприятия } \\
\text { АО УЭМ }\end{array}$ \\
\hline
\end{tabular}


Все мероприятия в рамках этих трех бизнес-процессов направлены на увеличение добавленной стоимости, созданной интеллектуальным капиталом.

На данный момент на предприятии АО УЭМ человеческий капитал имеет двукратную отдачу от вложения в человеческие ресурсы. Это хороший показатель, поэтому организации следует на первом этапе направить усилия на отдачу от вложения в структурный капитал, так как он является одним из элементов интеллектуального капитала организации, внедрить мероприятия, предложенные в данной главе. Мероприятия для увеличения отдачи от вложения в структурный капитал, предложенные в рамках данной модели управления интеллектуальной добавленной стоимостью, позволят АО УЭМ разработать стратегию и тактику в области управления структурным капиталом, осуществить координацию взаимодействия подразделений, служб и контрагентов предприятия, участвующих в процессе управления структурным капиталом, обеспечить высокую доходность сделок с объектами интеллектуальной собственности, как следствие, повысить интеллектуальную добавленную стоимость на промышленном предприятии АО УЭМ.

Далее рекомендуем также обратить внимание и на отдачу от задействованного капитала для увеличения добавленной стоимости на предприятии АО УЭМ, но это менее действенный способ, так как при оценке интеллектуальной добавленной стоимости данного предприятия понятно, что в данной организации более действенный способ получения добавленной стоимости идет именно от компонентов интеллектуального капитала, которыми человеческий и структурный капитал являются.

Для того чтобы иметь представление о том, как внедрение данных мероприятий на предприятие влияет на интеллектуальную добавленную стоимость, нужно по прошествии времени снова оценить коэффициент интеллектуальной добавленной стоимости Пулика. 


\section{ЗАКЛЮЧЕНИЕ}

Раскрытие теоретико-методических основ управления интеллектуальной добавленной стоимостью на предприятии потребовало рассмотреть подходы к определению интеллектуального капитала, его структуру и классификацию; определение добавленной стоимости и интеллектуальной добавленной стоимости и методик ее оценки. На основании данного анализа приходим к выводу, что в современной экономике нет единого определения как интеллектуального капитала, так и интеллектуальной добавленной стоимости. Однако в каждом подходе к определению интеллектуального капитала есть общая идея о том, что он основан на знаниях, не имеющих материальной формы, и очень важен для конкурентоспособности предприятия. В классификациях интеллектуального капитала также прослеживается общность: в каждой из них присутствуют человеческий и структурный капиталы.

В рамках данной работы предложено понимание интеллектуальной добавленной стоимости как стоимости, созданной благодаря интеллектуальному капиталу и охватывающей его реальный вклад в создание стоимости конкретного продукта, опираясь на классификацию элементов интеллектуального капитала по Т. Стюарту.

В ходе исследования было выявлено, что существует множество методов оценки интеллектуального капитала предприятия, однако для исследования интеллектуальной добавленной стоимости подходит всего один, нацеленный именно на это - метод VAIC (коэффициент интеллектуальной добавленной стоимости), автором которого является Анте Пулик. Данный коэффициент используется непосредственно для измерения интеллектуальной добавленной стоимости на предприятии. Далее были проанализированы исследования зарубежных и отечественных ученых - большинство авторов именно данный метод используют для проведения эмпирических исследований. Также в работе рассмотрены достоинства и не- 
достатки данного метода оценки интеллектуального капитала. Одно из главных достоинств данного метода заключается в простоте оценки и доступности данных.

В рамках исследовательской работы рассмотрены стратегии управления интеллектуальным капиталом, направленные на создание новой стоимости, реализованной в продуктах, с помощью рационального формирования и использования знаний в организации.

Рассмотрены состояние и проблемы создания интеллектуальной добавленной стоимости на промышленных предприятиях. В ходе данного анализа выявлено, что в среднем в едином временном промежутке интеллектуальная добавленная стоимость зарубежных промышленных предприятий выше и имеет более стабильные показатели коэффициента. Российским предприятиям нужно стремиться к повышению человеческого капитала для увеличения коэффициента интеллектуальной добавленной стоимости, так как существенная разница между зарубежными и отечественными показателями именно в нем.

В рамках проведённой исследовательской работы были сформулированы цель управления интеллектуальным капиталом, основные задачи и методы управления интеллектуальной добавленной стоимостью на промышленном предприятии; выявлены факторы, прямо влияющие на стоимость объектов интеллектуальной собственности, а также особенности принятия решений в ходе управления интеллектуальной добавленной стоимостью на предприятии. Решения, принимаемые при создании интеллектуальной добавленной стоимости, должны рассматриваться через систему управления интеллектуальными активами промышленного предприятия, что было проанализировано в магистерской работе.

В эмпирической части исследовательской работы была измерена интеллектуальная добавленная стоимость промышленного предприятия АО УЭМ. По результатам данной оценки сделан вывод о 
том, что самым важным компонентом коэффициента интеллектуальной добавленной стоимости для АО УЭМ является показатель добавленной стоимости (эффективности) человеческого капитала НСЕ, который показывает более чем двукратную отдачу от вложения в человеческие ресурсы. Для увеличения стоимости, добавленной интеллектуальным капиталом, нужно научиться управлять ею и применять данные методы на практике.

Для управления интеллектуальной добавленной стоимостью на промышленном предприятии была разработана модель управления интеллектуальной добавленной стоимостью и применена на ОА УЭМ.

В рамках данной модели управления интеллектуальной добавленной стоимостью на АО УЭМ рассмотрены бизнес-процессы управлением интеллектуальной добавленной стоимостью, определены входы и входы и расписаны мероприятия в рамках бизнеспроцессов, которые помогут повысить эффективность управления интеллектуальной добавленной стоимостью на предприятии и повысить конкурентоспособность предприятия.

По результатам оценки VAIC предприятия АО УЭМ было отмечено, что на данный момент промышленному предприятию следует направить усилия на отдачу от вложения в структурный капитал, так как он является одним из элементов интеллектуального капитала организации; внедрить мероприятия, предложенные в третьей главе. Для того чтобы отследить как внедрение данных мероприятий на предприятии влияет на интеллектуальную добавленную стоимость, нужно по прошествии времени снова оценить коэффициент интеллектуальной добавленной стоимости Пулика. 


\section{БИБЛИОГРАФИЧЕСКИЙ СПИСОК}

1. Pulic A. VAIC - an accounting tool for IC management // International Journal of Techology Management. 2000. P. 702-714.

2. Стюарт Т. Интеллектуальный капитал. Новый источник богатства организации / Новая постиндустриальная волна на Западе. Антология / под ред. В.А. Иноземцева. - М.: Academia, 2009. - 497 с.

3. Edvinsson L., Malone M. Intellectual Capital: Realizing Your Company's True Value by Finding Its Hidden Roots. - New York: HarperCollins Publishers, 1997. - 112 p.

4. Brooking A. Corporate Memory: Strategies for Knowledge Management. International Thomson Business. 2012. P. 231-264.

5. Руус Й., Пайк С., Фернстрем Л. Интеллектуальный капитал: практика управления / Пер. с англ. под ред. В.К. Дерманова. СПб.: Изд-во «Высшая школа менеджмента», 2009. - 152 с.

6. Albert S., Bradley K. The Impact of Intellectual Capital / Open University Business School Working Paper, 1996. - 155 p.

7. Леонтьев Б.Б. Цена интеллекта: Интеллектуальный капитал в российском бизнесе. - М.: Акционер, 2002.

8. Ивашковская И.В., Байбурина Э.Р. Роль интеллектуального капитала в создании стоимости крупных российских компаний: опыт эмпирического исследования. / Вестник Финансовой академии. 2007.

9. Осколкова М.А. Интеллектуальный капитал в оценке инвестиционной привлекательности компаний // Управление корпоративными финансами. - 2012. - № 6. - С. 344-376.

10. Сорокина М.С. Сущность и поэлементная структура добавленной стоимости // Научный журнал КубГАУ. - 2014. № 100(06).

11. Найденова Ю., Осколкова М. Трансформация интеллектуального капитала в ценность компании в экономике знаний // Кор- 
поративные финансы. - 2011. - № 2. - С. 93-125.

12. Головко Т.В., Байбурина Э.Р. Эмпирическое исследование интеллектуальной стоимости крупных российских компаний и факторов ее роста // Корпоративные финансы. - 2008. - № 2 (6).- С. 5-7.

13. Козырев А.Н. и др. Проблемы методологии оценки интеллектуальной собственности // Интеллектуальная собственность. 2010. - № 8. - C. 38-47.

14. Caddy, I. Intellectual capital: recognizing both assets and liabilities. / I. Caddy // Journal of Intellectual Capital. 2010. № 2. p. 129-146.

15. Гражданский кодекс Российской Федерации. Части первая, вторая, третья и четвертая: текст и изменениями и дополнениями. - М.: Эксмо, 2018. - 576 с.

16. Положение по бухгалтерскому учету «Учет нематериальных активов» (ПБУ 14/2007) [электронный ресурс]. URL: http://www.consultant.ru/ (дата обращения 01.08.2019).

17. Яненко В.К. Достаточно ли для инвесторов информации о нематериальных активах, содержащейся в финансовой отчетности? // Вестник Финансовой Академии. - 2008. - № 1. - С. 116-120.

18. Быкова А.А., Молодчик М.А. Влияние интеллектуального капитала на результаты деятельности компании // Вестник С.Петерб. ун-та. сер. Менеджмент. - 2011. - № 1. - С. 29-55.

19. Wang W.-Y., Chang C. Intellectual Capital and Performance in Causal Models // Journal of Intellectual Capital. 2005. Vol. 6. N 2. P. 222-236.

20. Bontis N., Richardson S. Intellectual capital and business performance in Malaysian industries // Journal of Intellectual Capital. 2000. Vol.1, No.1. P. 85-100.

21. Firer S., Mitchel S., Williams. Intellectual capital and traditional measures of corporate performance // Journal of Intellectual Capi- 
tal. 2003. Vol.4, No.3. P. 348-360.

22. Pulic A. VAIC - an accounting tool for IC management // International Journal of Techology Management. 2000. Vol 20. No.5. P. 702-714.

23. Sveiby K.E.: Intellectual Capital and Knowledge Management, 1998. $213 \mathrm{p}$.

24. Chen M.C., Cheng S.J., Hwang Y. An empirical investigation of the relationship between intellectual capital and firms' market value and financial performance // Journal of Intellectual Capital, 2005, 6 (2).

25. Tan, H. P., D. Plowman, and P. Hancock. Intellectual capital and financial returns of companies // Journal of Intellectual Capital. 2000. Vol. 8 No. 1, 2007, P. 76-95.

26. Edvinsson L., Malone M.: Intellectual Capital: Realizing Your Companys True Value by Finding Its Hidden Roots. - New York: HarperCollins Publishers, 2007. - 125 p.

27. Martin Clarke, Dyna Seng and Rosalind H. Whiting Intellectual Capital and Firm Performance in Australia. // Department of Accountancy and Business Law, Working paper series no 12. 2010.

28. Кулагин А., Курнышева И. Национальное богатство России и инновационный потенциал // Вопросы экономики. -2010 . - № 5. - c. 88-93.

29. Азимов Э.Г., Щукин А.Н. Словарь методических терминов (теория практика преподавания языков). - М., 2009. - 201 с.

30. Маркс К. Капитал (IV том) // Маркс К., Энгельс Ф. Соч. 2ое изд. - Т. 26. - Ч. 1. - М.: Государственное издательство политической литературы, 1962. - 421 с.

31. Fisher, I. Senses of Capital / I.Fisher // Econ. J. 1987. № 7. P. 201-202

32. Shahid Amin, Shoaib Aslam. Intellectual Capital and Financial Performance of Pharmaceutical Firms in Pakistan // Pakistan Journal of Social Sciences (PJSS) Vol. 34, No. 2 (2014), P. 433-450.

33. Бурганова Л.А. Теория управления. - М.: ИНФРА-М., 
2011. $-270 \mathrm{c}$.

34. Леонтьев Б.Б. Цена интеллекта. Интеллектуальный капитал в российском бизнесе / Б.Б. Леонтьев. - М.: «Акционер», 2012. $200 \mathrm{c}$.

35. Багов В.П. Управление интеллектуальным капиталом: учебное пособие / В.П. Багов, Е.Н. Селезнёв, В.С. Ступаков. - М.: ИД «Камерон», 2012. - 248 с.

36. Лукичева Л.И. Управление интеллектуальным капиталом: учебное пособие / Л.И. Лукичева. - М.: Омега-Л, 2009. - 551 с.

37. Индикаторы инновационной деятельности 2016: статистический сборник. - Москва: НИУ ВШЭ, 2018.

38. Супрун В.А. Интеллектуальный капитал: главный фактор конкурентоспособности экономики в XXI веке. - М.: Книжный дом «ЛИБРОКОМ», 2010. - $192 \mathrm{c}$.

39. Инновационная деятельность в Российской Федерации: информационно - статистический материал. Москва. 2018.

40. Официальный сайт УГМК. Режим доступа https://www.ugmk.com/analytics/surveys_major_markets/copper/ (дата обращения 01.08.2019).

41. Официальный сайт ОА «Уралэлектромедь»- Режим доступа http://www.elem.ru/ru/about-complex/us/ (дата обращения 01.08.2019).

42. Официальный сайт «Русская медная компания» - Режим доступа www.rmk-group.ru/ (дата обращения 01.08.2019).

43. Официальный сайт «Норильский Никель»- Режим доступа https://www.nornickel.ru/ (дата обращения 01.08.2019).

44. Официальный сайт «BHP Billiton Group» - Режим доступа https://www.bhp.com/ (дата обращения 01.08.2019).

45. Официальный сайт «PhelpsDodge» - Режим доступаһttps://phelpsdodge.com.ph (дата обращения 01.08.2019).

46. Официальный сайт «Codelco» - Режим доступа https://www.codelco.com/ (дата обращения 01.08.2019). 
47. Кельчевская Н.Р., Сироткин С.А., Пелымская И. С., Исмагилова Г.В., Вольф Ф.В., Слукина С.А, Черненко И.М. Бизнеспроцессы промышленного предприятия: учебное пособие. Екатеринбург: Изд-во Урал. ун-та, 2016. - 339 с.

48. Гапоненко Т.В., Дьяченко Е.А. Организация управления интеллектуальным капиталом в условиях становления экономики знаний // Вестник Донского государственного технического университета. - 2009. - Т. 9. - № 2 (41). - С. 322-326.

49. Блинов С.С. Факторы, определяющие выбор подхода к оценке интеллектуального капитала. - Пермь: Высшая школа экономики, 2011. - 34 с.

50. Елиферов В.Г., Репин В.В. Бизнес-процессы. Регламентация и управление. - М.: ИНФРА-М, 2005. -319 с.

51. Fitzenz J. The ROI of human capital: measuring the economic value of employee performance / J. Fitzenz. New York - Washington D.C., 2009

52. Сетевое издание «Центр раскрытия корпоративной информации» - Режим доступа http://www.e-disclosure.ru/ portal/files.aspx?id=2003\&type=3 (дата обращения 01.08.2019).

53. Домбровская Е.Н. О практическом применении различных методов оценки интеллектуального капитала. - Новосибирск: СибАК, 2014.

54. Цуриков С.В. Проблемы оценки интеллектуального капитала организации // Корпоративный менеджмент. - 2009. - № 3

55. Гаранина Т.А. Роль нематериальных активов в создании ценности компании: теоретические и практические аспекты // Корпоративные финансы. -2009.

56. Faris Nasif AL-SHUBIRI The impact of Value Added Intellectual Coefficient components on financial health // Review of International Comparative Management. 2013.

57. Daniela Carlucci, Gianni Schiuma \& Bernard Marr. The knowledge value chain: how intellectual capital impactson business per- 
formance // Int. J. Technology Management. 2004. № 27.

58. Mehrnaz Paknezhad \& Ahmad Ahmadkhani. Value added intellectual coefficient (VAIC): an empirical study // Management Science Letters. 2012. № 2.

59. Маслова И.А. Методические аспекты оценки стоимости предприятия // Управленческий учет. - М.: ЗАО «Финпресс», 2010. № 3. - C. 22-31.

60. Stewart T. A. Intellectual Capital. The New Wealth of Organizations/ T. A. Stewart // New York : Currency Doubleday. 1997. № 4. P. 64.

61. Беккер Г. Человеческий капитал. Воздействие на заработки инвестиций в человеческий капитал / Г. Беккер. - М.: Экономика, 2010. - 186 c.

62. Антонов И. Ю. Общие механизмы стимулирования инновационно-инвестиционных процессов в России // Бизнес в законе. 2012. - № 6.- С. 260-262.

63. Валдайцев С.В. Оценка бизнеса и инноваций. - М.: Информационно-издательский дом «Филин», 2010. - 336 с.

64. Джамай Е.В., Бендиков М.А. «Интеллектуальный капитал развивающейся фирмы: проблемы идентификации и измерения» // Менеджмент в России и за рубежом. - 2001. - № 4.

65. Антонов И.Ю. Основные направления инновационного развития экономики России // Бизнес в законе. - 2012. - № 6. C. 257-259.

66. Брукинг Э. Интеллектуальный капитал: ключ к успеху в новом тысячелетии / Пер. с англ., под ред. Л.Н. Ковачин. - СПБ: Питер, 2001. $-288 \mathrm{c}$. 

Кельчевская Наталья Рэмовна - доктор экономических наук, профессор, зав. кафедрой экономики и управления на металлургических и машиностроительных предприятиях Высшей школы экономики и менеджмента Уральского федерального университета имени первого Президента России Б.Н. Ельцина, Заслуженный работник Высшей школы РФ.

Пелымская Ирина Сергеевна - кандидат экономических наук, доцент, доцент кафедры экономики и управления на металлургических и машиностроительных предприятиях Высшей школы экономики и менеджмента Уральского федерального университета имени первого Президента России Б.Н. Ельцина.

Баскакова Ирина Владимировна - кандидат экономических наук, доцент кафедры и экономической теории и экономической политики Высшей школы экономики и менеджмента Уральского федерального университета имени первого Президента России Б.Н. Ельцина. 
Кельчевская Наталья Рэмовна

Пелымская Ирина Сергеевна

Баскакова Ирина Владимировна

\title{
УПРАВЛЕНИЕ ИНТЕЛЛЕКТУАЛЬНОЙ ДОБАВЛЕННОЙ СТОИМОСТЬЮ НА ПРОМЫШЛЕННОМ ПРЕДПРИЯТИИ
}

\author{
монография \\ Выпускающий редактор: Цветкова А.В. \\ Корректор: Куракин Н.В. \\ Верстальщик: Журавлева В.А.
}

издательство

Креативная

экономика
Издание научных монографий:

mono@idbg.ru

$+74952150138$

88003331538 (звонок бесплатный)

\section{Информация для авторов:}

www.bgscience.ru

Усл. печ. л. 6,0. Тираж 500 экз.

Подписано в печать 07.10.2019

Формат: 60x84/16

Отпечатано: ПАО «Т8 Издательские Технологии»

109316 Москва, Волгоградский проспект, дом 42, корпус 5

Тел.: +7 (499) 322-38-30 